\title{
Subsurface and Reservoir Analysis of the Upper Devonian Fourth Sand in Taylor County, West Virginia
}

Julia Dare McConnell

West Virginia University

Follow this and additional works at: https://researchrepository.wvu.edu/etd

\section{Recommended Citation}

McConnell, Julia Dare, "Subsurface and Reservoir Analysis of the Upper Devonian Fourth Sand in Taylor County, West Virginia" (2011). Graduate Theses, Dissertations, and Problem Reports. 3287.

https://researchrepository.wvu.edu/etd/3287

This Thesis is protected by copyright and/or related rights. It has been brought to you by the The Research Repository @ WVU with permission from the rights-holder(s). You are free to use this Thesis in any way that is permitted by the copyright and related rights legislation that applies to your use. For other uses you must obtain permission from the rights-holder(s) directly, unless additional rights are indicated by a Creative Commons license in the record and/ or on the work itself. This Thesis has been accepted for inclusion in WVU Graduate Theses, Dissertations, and Problem Reports collection by an authorized administrator of The Research Repository @ WVU. For more information, please contact researchrepository@mail.wvu.edu. 


\title{
Subsurface and Reservoir Analysis of the Upper Devonian Fourth Sand in Taylor County, West Virginia
}

\author{
Julia Dare McConnell
}

\author{
Thesis submitted to the \\ Eberly College of Arts and Sciences \\ at West Virginia University \\ in partial fulfillment of the requirements \\ for the degree of
}

\author{
Master of Science \\ in \\ Geology
}

\author{
Timothy R. Carr, Ph.D., Chair \\ Richard Smosna, Ph.D. \\ Jaime Toro, Ph.D. \\ Department of Geology and Geography
}

\author{
Morgantown, West Virginia \\ 2011
}

Keywords: Fourth, Venango Group, North-Central West Virginia, Upper Devonian, Appalachian Basin

Copyright 2011 Julia Dare McConnell 


\section{ABSTRACT \\ Subsurface and Reservoir Analysis of the Upper Devonian Fourth Sand in Taylor County, West Virginia Julia Dare McConnell}

The Upper Devonian Venango Group of West Virginia is a major Appalachian gas play. Best known by their informal driller's names, these shallow, multiple sandstone and siltstone reservoirs formed in fluvial, deltaic, interdeltaic shoreline, shelf, and slope depositional environments of the Catskill delta complex. However, these numerous units are difficult to correlate, resulting in reservoir identification problems.

The "Fourth Sand", one of the many units of the Venango Group is the topic of study for an integrated subsurface reservoir analysis in Taylor County, north-central West Virginia. The data includes paper and electric log data, multiple rotary sidewall cores, and well-test data, which are analyzed to investigate depositional relationships, connectivity and geometry of sandbodies, and petrophysical parameters of the reservoir. This information can be used to improve the characterization of the "Fourth Sand", as well as to other Upper Devonian sandstone and siltstone reservoirs. Improved reservoir characterization can open new opportunities to expand natural gas resources. 


\section{ACKNOWLEDGEMENTS}

I would like to thank my graduate committee for all of their understanding, assistance, and advice that made the completion of this project possible. I especially would like to thank my advisor Dr. Carr for his consistent patience and strong guidance throughout this project. I would also like to thank the West Virginia University faculty and fellow graduate colleagues for all of their help and support. In addition, I could not forget my family for their constant love and support.

I would also like to thank Tom Carpenter and Alan Smith from Petroleum Development Corporation for their invaluable intern opportunity, graduate funding, and data for making this project possible. In addition, I would like to thank Gregory Wrightstone from Texas Keystone, Inc. for providing sample data and additional log data used to supplement this project. 


\section{TABLE OF CONTENTS}

ABSTRACT ii

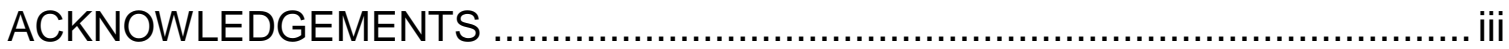

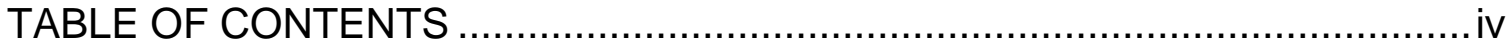

LIST OF FIGURES

INTRODUCTION

STUDY AREA AND DATA

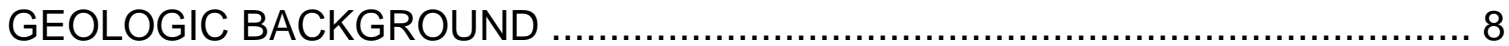

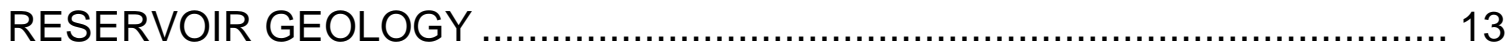

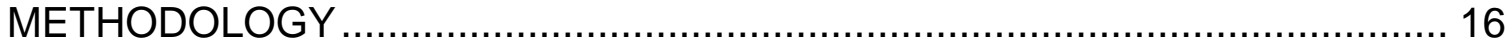

DESCRIPTION AND INTERPRETATION OF THE FOURTH SAND UNITS ..... 25

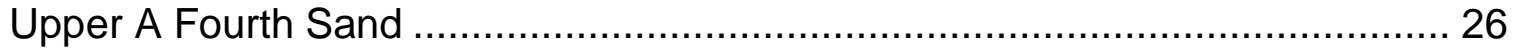

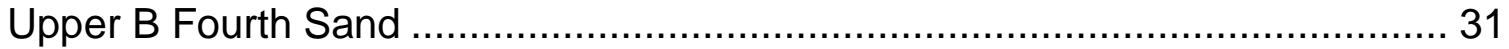

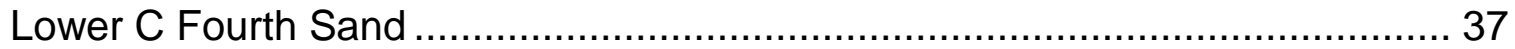

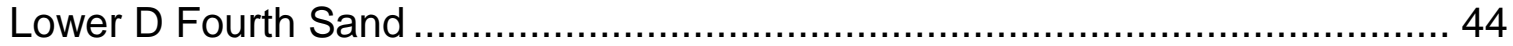

SAMPLE DATA

Thin Section Description and Interpretation ............................................... 50

RESERVOIR CHARACTERISTICS AND PRODUCTION DATA ......................62

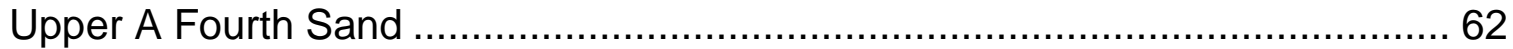

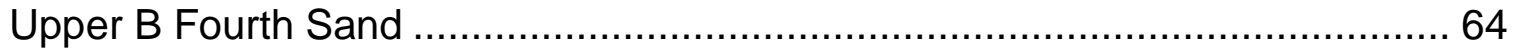

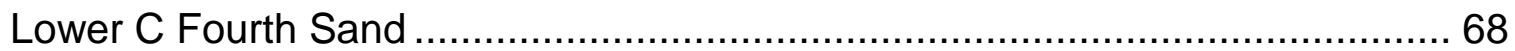

Lower D Fourth Sand ……................................................................. 72

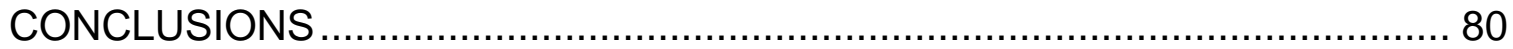

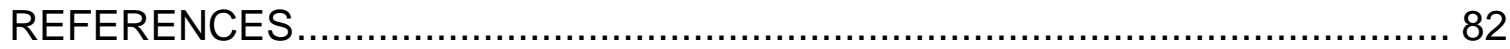




\section{LIST OF FIGURES}

Figure 1. The study area located in Taylor County, north-central West Virginia is within the Appalachian plateau province. Taylor County is highlighted in red (modified after the WV Geological and Economic Survey, 2005 and Benbennick, 2006).......................... 4

Figure 2. Study area in Taylor County, West Virginia showing the location of 475 well locations with subsurface data that were used in the study ....................................... 5

Figure 3. Subsurface (subsea) structure map on the top of the Fourth sandstone showing low-amplitude folds of the eastern Appalachian plateau province. Red illustrates structural highs and blue illustrates structural lows. Contour interval $(\mathrm{Cl})$ is 50

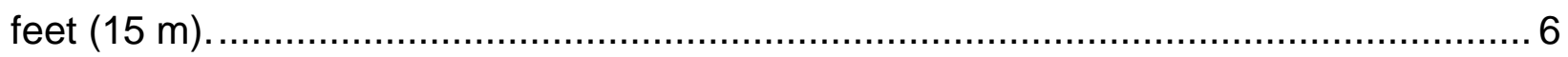

Figure 4. Generalized stratigraphic nomenclature of the Upper Devonian Venango Group with driller-defined sandstone units used in the study area. The Fourth sandstone, which is the focus of this study, is highlighted in yellow. 7

Figure 5. Structural cross-section illustrating the Devonian Acadian orogeny. The Upper Devonian sandstone units were deposited in the Catskill foreland basin (modified after Fichter, 1993).

Figure 6. Image A illustrates a block model of the Catskill deposition in the Appalachian shallow foreland-ramp basin. Image B depicts a cross-section of shoreline progradation to the northwest related to the tectonic uplift to the southeast and increased sedimentation (modified after Castle, 2000). 10

Figure 7. Upper Devonian fluvial-deltaic systems prograding to the northwest. The study in Taylor County is located near the area of maximum propagation for lobe 4 (shaded in yellow) in northern West Virginia (modified after Boswell and Jewell, 1988).

Figure 8. Idealized depositional model of the Upper Devonian Venango Group into a shallow foreland-ramp basin, northern West Virginia (modified after Boswell and Donaldson, 1988). 14

Figure 9. Correlation type log: Petroleum Development Corporation Williams-560. Gamma-ray (cutoff of $90 \mathrm{API}$ ), deep resistivity, bulk density, density porosity (2.73 
$\mathrm{gm} / \mathrm{cm}^{3}$ ), and neutron porosity digital-log curves are displayed in tracks 1,2 , and 3 . Cross-over of the density and neutron porosity curves is highlighted in red and indicates the presence of gas. Interpretation of bulk volume water (blue) and hydrocarbon saturation (pink) is illustrated in track 4. Perforation interval is shown in track 1. Reported porosity from core plugs is illustrated in track 4 and show general agreement with porosity. One rotary sidewall core with accompanying core data is located at a depth of 2080 feet (Location of the type log-core well is displayed in Figure 2). Mapped and interpreted horizons are shown to the left and in subsequent sections defined and discussed.

Figure 10. Base map illustrating the network of strike and dip cross sections constructed, and used to correlate the Fourth Sand across the study area. 18

Figure 11. Pickett plot of type log Petroleum Development Corporation Williams-560 showing the hydrocarbon-bearing zone (circled in red) in the depth interval $2041-2089$ feet. The points trailing downward forming a vertical pattern indicating that the change in saturation is a result of a decrease in porosity below levels that can contain hydrocarbons.

Figure 12. Upper A Fourth Sand Type Log: Petroleum Development Corporation Williams-560. The Upper A sandbody has a serrated, funnel-shaped log signature with a coarsening (cleaning) upwards pattern (red arrow) and sharp upper surface (interpreted flooding surface). 27

Figure 13. Upper A Fourth Sand density-neutron lithology crossplot for type log: Petroleum Development Corporation Williams-560. The plot indicates that the interval may contain significant carbonate (limestone) component, and has a relatively low porosity interval $(<5 \%)$. The horizontal trend along the zero percent density porosity, indicated by increased apparent neutron porosity is related to increase shale content. 28

Figure 14. Upper A Fourth Sand RHOmaa-Umaa mineralogy crossplot for log: Petroleum Development Corporation Frey-808. Prominent lithic components consist of

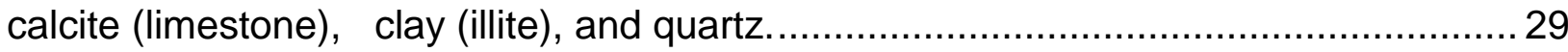


Figure 15. Upper A Fourth Isopach Map. Distribution is widespread with an average gross sand of 36 feet thick $(11 \mathrm{~m})$ across the study area. Lobate geometry of thick and thin areas define weak northeast-southwest trends defining a series of lobate shorelines along the strike of the foreland ramp basin. The maximum basin-ward shoreline of the Upper A Fourth Sand unit is interpreted to the northwest of the study area. Contour

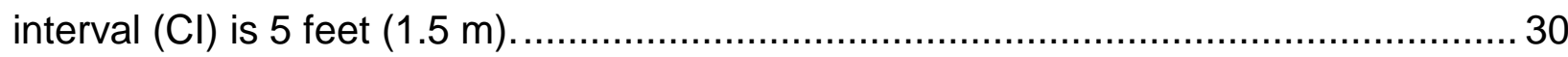

Figure 16. Upper B Fourth Sand Type Log: Petroleum Development Corporation Williams-560. The Upper B sandbody has a serrated, cylinder or blocky-shaped log signature with sharp lower and upper surfaces. Crossover of the density and neutron porosity curves (track 3 ) are highlighted in red and indicate the presence of gas, which is also evident in the interpretation track 4. Core data (black triangles) plot on the average of density and neutron porosity (track 4), which also shows the computed hydrocarbon saturation. 32

Figure 17. Upper B Fourth Sand density-neutron lithology crossplot for type log: Petroleum Development Corporation Williams-560. Data points located above the sandstone lithology line indicates the presence of gas and data points with low density porosity drifting to increased neutron porosity indicate the increased presence of clay. 34

Figure 18. Upper B Fourth Sand RHOmaa-Umaa mineralogy crossplot for log: Petroleum Development Corporation Frey-808. Prominent lithic components consist of quartz, feldspar, and clay (illite). The Upper B Fourth Sand in contrast to the Upper A Fourth Sand (Figure 14) contains negligible calcite. The red triangle is lithology based on XRD mineralogy from a nearby well (Petroleum Development Corporation Williams560). The core data is from a cleaner Upper B Fourth sandstone, but confirms the

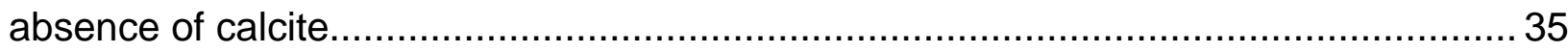

Figure 19. Upper B Fourth Isopach Map. Distribution is thick with an average gross sand of 35 feet $(11 \mathrm{~m})$ across the study area. The distribution consists of two thick areas oriented northwest-southeast separated by an area of thin sandstone. The thin area is interpreted as an interfluve between two channel complexes. Contour interval (Cl) is 5 feet $(1.5 \mathrm{~m})$. 36 
Figure 20. Lower C Fourth Sand Type Log: Petroleum Development Corporation Williams-560. The red arrow indicates that the Lower C sandbody has a serrated, funnel-shaped log signature with a coarsening (cleaning) upwards pattern (red arrow) and sharp upper surface. 38

Figure 21. Lower C Fourth Sand density-neutron lithology crossplot for type log: Petroleum Development Corporation Williams-560. The plot indicates that the interval may contain significant carbonate (limestone) component. The horizontal trend along the zero percent density porosity, indicated by increased apparent neutron porosity is related to a shale-rich content. 39

Figure 22. Lower C Fourth Sand RHOmaa-Umaa mineralogy crossplot for type log: Petroleum Development Corporation Frey-808. Prominent lithic components consist of calcite (limestone), clay (illite), and quartz. 40

Figure 23. Lower C Fourth Sand Isopach Map. Distribution is concentrated in the northeast of the study area, but relatively thin with an average gross sand of 7 feet (2 $\mathrm{m})$. 41

Figure 24. A-A' northeast to southwest stratigraphic cross-section line located across the study area. 42

Figure 25. A-A' stratigraphic cross-section illustrating the Lower C and Lower D Fourth Sand units thin across the study area from the northeast to southwest. The Lower $\mathrm{C}$ and Lower $D$ is interpreted to have been eroded by the overlying Upper B Fourth fluvialdeltaic systems. Thinning and erosion to the southwest is indicated by the black arrows.

Figure 26. Lower D Fourth Sand Type Log: Petroleum Development Corporation Williams-560. The Lower D sandbody has a blocky-serrated log signature with sharp lower and upper surfaces.

Figure 27. Lower D Fourth Sand density-neutron lithology crossplot for log: Petroleum Development Corporation Frey-808. Data points located above the sandstone lithology line indicate the presence of gas. As density porosity decreases to zero, the neutron porosity indicates the presence of clay 
Figure 28. Lower D Fourth Sand RHOmaa-Umaa mineralogy crossplot for log: Petroleum Development Corporation Frey-808. Prominent lithic components consist of quartz, feldspar, and clay (illite). The red triangle is the location of the one rotary sidewall core: Petroleum Development Corporation Williams-560 based on XRD, mineralogy, and relative clay abundances data. 47

Figure 29. Lower D Fourth Isopach Map. Distribution is relatively thick with an average gross sand of 16 feet $(5 \mathrm{~m})$ and is in northwest-southeast geometry. Contour interval (Cl) is 5 feet $(1.5 \mathrm{~m})$. 48

Figure 30. One rotary sidewall core XRD, mineralogy, and relative clay abundances data for Petroleum Development Corporation Williams-560 at a sample depth of 2080 feet. Quartz, plagioclase, and illite highlighted in yellow were used as mineral endpoints to calibrate RHOmaa-Umaa crossplots (Figure 18). 51

Figure 31. Thin section of the one rotary sidewall core and blue epoxy represents open pore space (intergranular porosity and dissolution porosity). 52

Figure 32. Thin section of a large quartz grain with undulatory extinction to the right. An elongate muscovite grain is present in the upper left corner. 53

Figure 33. Thin section of plagioclase feldspar with lamellar (albite) twinning to the right.

Figure 34. Pictures A and B: Thin section of a squeezed muscovite crystal between quartz grains. 55

Figure 35. Thin section of a chlorite mineral with medium green to olive green colors (anomalous birefringence). 56

Figure 36. Thin section of reddish-brown, partially opaque, angular clay fragments between quartz grains and clay material coating quartz grains........ 57

Figure 37. Thin section of a large, irregular calcite cement grain between quartz grains. 59

Figure 38. Thin section of a rounded chert rock fragment. 60 
Figure 39. Upper A Fourth Net Sand Map with a gamma-ray cutoff of 90 API. Sand distribution is concentrated to the southwest with an average thickness of 7 feet $(2 \mathrm{~m})$. Contour interval $(\mathrm{Cl})$ is 5 feet $(1.5 \mathrm{~m})$.

Figure 40. Upper B Fourth Net Sand Map with a gamma-ray cutoff of 90 API. Sand distribution is thick (average 17 feet) throughout the study area and prominent to the northwest. Contour interval $(\mathrm{Cl})$ is 5 feet $(1.5 \mathrm{~m})$. 65

Figure 41. Upper B Fourth Degree of Cross-over Map with an average of 8 to 10 feet (2.5 to $3 \mathrm{~m})$. Contour interval $(\mathrm{Cl})$ is 2 feet $(0.6 \mathrm{~m})$ 66

Figure 42. Pickett plot for Upper B Fourth Sand Type Log: Petroleum Development Corporation Williams-560, depth interval 2041 - 2089 feet. The Upper B Fourth Sand is interpreted as hydrocarbon and water saturated. One rotary sidewall core is found at a depth of 2080 feet. 67

Figure 43. Upper B Fourth Sand Production Bubble Map. Optimal hydrocarbon production is located in the northeast corner of the study area. 69

Figure 44. Upper B Fourth Sand Production Scatter Plot. The relationship between the degree of cross-over and feet of net sand indicates that the Upper B Fourth Sand can be found productive with 10 to 20 feet ( 3 to $6 \mathrm{~m}$ ) of net sand. There are no productive wells within less than 8 to 10 feet ( 2 to $3 \mathrm{~m}$ ) of density-neutron cross-over. 70

Figure 45. Lower C Fourth Net Sand Map with a gamma-ray cutoff of 90 API. Distribution is negligible with an average thickness of 1 foot $(0.3 \mathrm{~m})$. Contour interval (Cl) is 5 feet $(1.5 \mathrm{~m})$. 71

Figure 46. Lower D Fourth Net Sand Map with a gamma-ray cutoff of 90 API. Distribution is thin with an average of 7 feet $(2 \mathrm{~m})$ across the study area and thins to the southwest as a result of partial removal by erosional down cutting of the Upper B Fourth

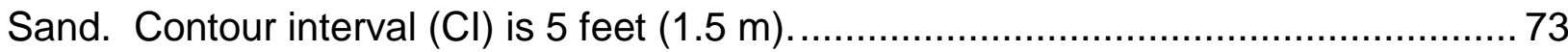

Figure 47. Lower D Fourth Sand Degree of Cross-over Map with an average of 6 to 8 feet $(1$ to $2.5 \mathrm{~m})$. Contour interval $(\mathrm{Cl})$ is 2 feet $(0.6 \mathrm{~m})$...... 74 
Figure 48. Pickett plot for Lower D Fourth Sand Type Log: Petroleum Development Corporation Williams-560, depth interval $2115-2142$ feet. For the type log, the Lower D Fourth Sand is interpreted as water saturated.

Figure 49. Pickett plot for Lower D Fourth Sand: Petroleum Development Corporation Frey-808, depth interval $2544-2577$ feet. The Lower D Fourth Sand is interpreted as hydrocarbon saturated. 76

Figure 50. Lower D Fourth Sand Production Bubble Map. Hydrocarbon production is limited across the study area. 77

Figure 51. Lower D Fourth Sand Production Scatter Plot. The relationship between the degree of cross-over and feet of net sand indicates that the Lower D Fourth Sand can be found productive with approximately 10 feet $(3 \mathrm{~m})$ of cross-over and at least 8 feet $(2$ $\mathrm{m})$ of net sand. 79 


\section{INTRODUCTION}

Natural gas production from the Upper Devonian Venango Group extends from north-central Pennsylvania to southern West Virginia (Roen et al., 1996). Known by their informal driller's names, the Venango Group is divided into numerous reservoirs based on a top-to-bottom counting method: the Gantz, Fifty-Foot, Thirty-Foot, Gordon Stray, Gordon, Fourth, Fifth and Bayard. Interpreted as part of the Catskill delta complex, these shallow sandstone and siltstone Venango reservoirs formed in fluvial, deltaic, interdeltaic shoreline, shelf, and slope depositional environments (Roen et al., 1996; Boswell and Jewell, 1988). Although difficult to correlate, the identification of these individual sandstone units presents a challenge to improving our understanding of reservoir geometry and continuity, depositional patterns, and to efficient exploration, development, and production of the Venango Group.

Previous publications related to the Venango Group have included several stratigraphy studies on the Upper Devonian - Lower Mississippian Catskill delta sandstone units in northern West Virginia. Lewis (1983) compiled subsurface mapping and outcrop section work, from which five major depositional facies were identified. Mumcuoglu (1984) utilized subsurface data and mapping to determine criteria to identify facies and their depositional environments related to oil and gas production. Peace (1985) correlated and mapped oil and gas sandstone units, along five strike and dip sections and recognized depositional environments. Boswell (1985) completed a subsurface mapping and outcrop study to reconstruct the depositional processes of the

Catskill delta complex. Another publication related to the Venango Group includes a 
regional interpretation incorporating surface and subsurface data in southeastern West Virginia (Jewell, 1988).

The following research utilizes an integrated subsurface and reservoir analysis using paper and digital-log data, available sample data, and well-test data to improve our understanding of selected Upper Devonian sandstone and siltstone reservoirs in Taylor County, north-central West Virginia. The present study focuses on the Fourth Sand, one of the lower reservoir units within the Venango Group. The Fourth Sand is an argillaceous sandstone with a low-resistivity log signature, but is gas productive. Specific project objectives of this study include:

(1) Develop a regional correlation framework and construct a regional crosssection grid tying together all wells having penetrated the Fourth Sand.

(2) Generate structure, isopach, and reservoir maps.

(3) Interpret depositional environments.

(4) Geologically characterize the Fourth Sand.

(5) Determine petrophysical properties of the Fourth Sand and non productive units.

Distribution, lithology, connectivity and geometry of reservoir sandbodies, as well as petrophysical parameters of the Fourth Sand were investigated. This information can be used to better characterize the depositional environment of the Upper Devonian Fourth Sand and possibly contribute to improved production. 


\section{STUDY AREA AND DATA}

The study area covers approximately 176 square miles (455 square $\mathrm{km}$ ) across the Fairmont East, Gladesville, Rosemont, Grafton, and Thornton topographic quadrangles in Taylor County, north-central West Virginia (Figures 1 and 2). Taylor County is located within the shallow natural gas belt of the Appalachian basin, where numerous stacked sandstone reservoir units are productive, and drilling depths range between 2,000 and 6,000 feet (610-1829 m) (Ryder, 1995). The study area is located on the eastern side of the Appalachian plateau province (Figure 1), where gently dipping rocks and broad open folds are prominent (Figure 3). The majority of natural gas discovered in the basin is located in the Appalachian plateau (Lessing, 1996).

The focus of this study is on the Upper Devonian Fourth Sand, one of the numerous informal driller-named sandstone units within the Venango Group (Figure 4). 475 paper and digital-logs with co-mingled production from the Fourth Sand reservoir units were selected. Available sample data includes one Upper Devonian Fourth Sand rotary sidewall core with accompanying X-ray diffraction (XRD), mineralogy, and relative clay abundances data. A thin section was also prepared from the rotary sidewall core. All of the log and core data were imported into standard industry interpretation software (GeoGraphix) for subsurface and petrophysical analyses of the Fourth Sand. 


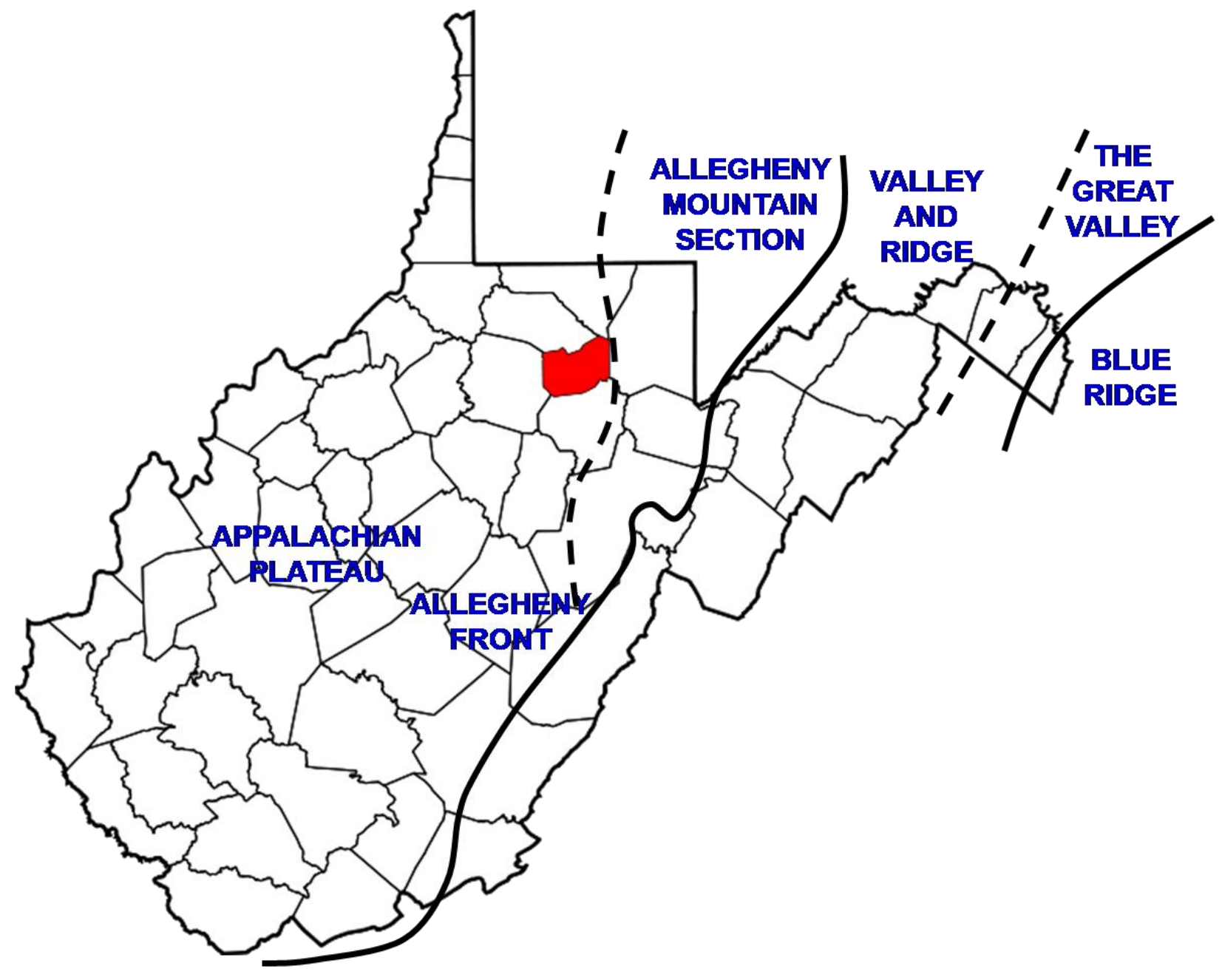

Figure 1. The study area located in Taylor County, north-central West Virginia is within the Appalachian plateau province. Taylor County is highlighted in red (modified after the WV Geological and Economic Survey, 2005 and Benbennick, 2006). 


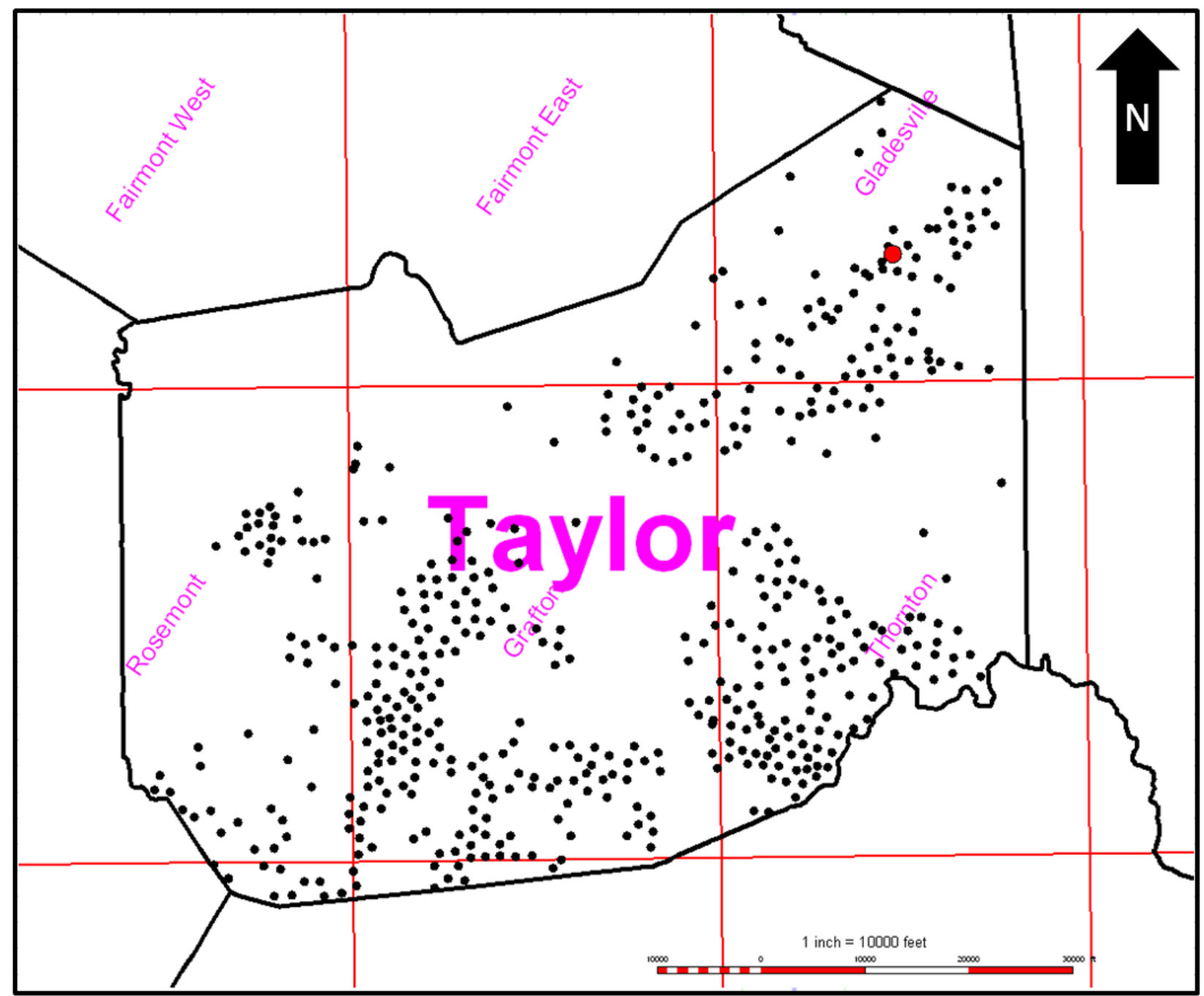

Map Legend

Well Location

Type Log-Core Plug

Figure 2. Study area in Taylor County, West Virginia showing the location of 475 well locations with subsurface data that were used in the study. 


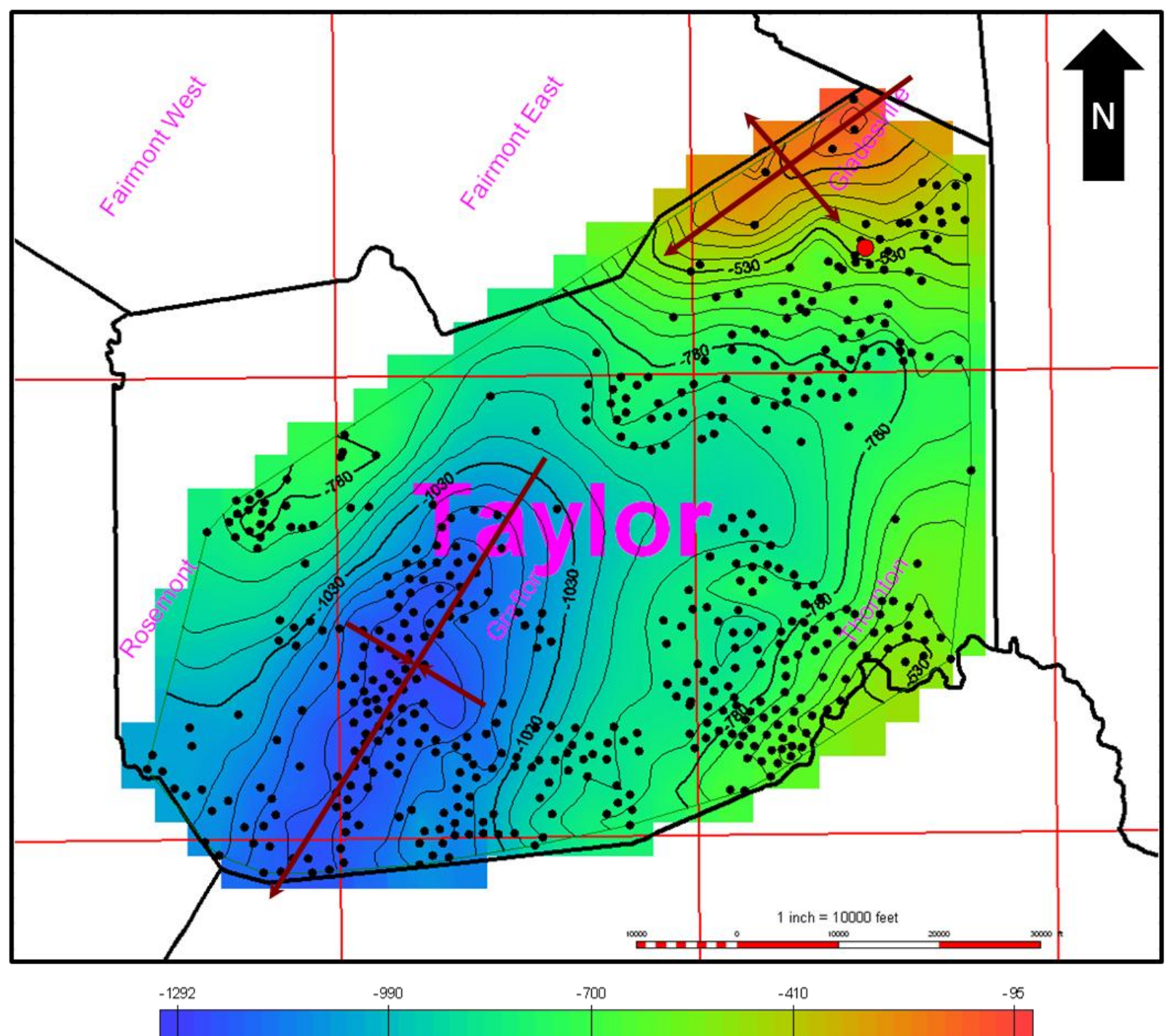

Map Legend

Well Location

Type Log-Core Plug

$\longleftrightarrow$ Anticline

$\rightarrow \longleftarrow$ Syncline

Figure 3. Subsurface (subsea) structure map on the top of the Fourth sandstone showing low-amplitude folds of the eastern Appalachian plateau province. Red illustrates structural highs and blue illustrates structural lows. Contour interval $(\mathrm{Cl})$ is 50 feet $(15 \mathrm{~m})$. 


\begin{tabular}{|c|c|c|}
\hline AGE & GROUP & DRILLER'S NOMENCLATURE \\
\hline \multirow{8}{*}{ 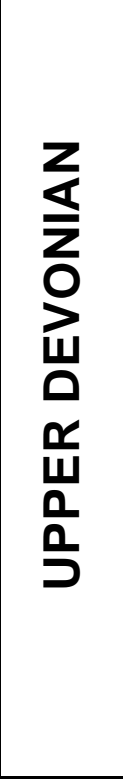 } & \multirow{8}{*}{$\begin{array}{l}0 \\
\text { O } \\
z \\
\sum \\
\text { W }\end{array}$} & Gantz Sandstone \\
\hline & & Fifty Foot Sandstone \\
\hline & & Thirty Foot Sandstone \\
\hline & & Gordon Stray \\
\hline & & Gordon Sandstone \\
\hline & & Fourth Sandstone \\
\hline & & Fifth Sandstone \\
\hline & & Bayard Sandstone \\
\hline
\end{tabular}

Figure 4. Generalized stratigraphic nomenclature of the Upper Devonian Venango Group with driller-defined sandstone units used in the study area. The Fourth sandstone, which is the focus of this study, is highlighted in yellow. 


\section{GEOLOGIC BACKGROUND}

In the late Devonian (385-360 million years), proto-North America was dominated by tropical climates that were warm and moderately humid (Milici and Swezey, 2006). Ongoing continental plate collisions occurred between proto-North America and Avalonia, an event known as the Acadian orogeny (Figure 5). The Appalachian basin, a shallow foreland-ramp basin formed in response to the plate collisions and deformation (Castle, 2000). Throughout the Acadian orogeny, large volumes of fluvial-deltaic siliclastic sediments were deposited in the basin, known as the Acadian delta complex. The Acadian delta complex consists of two delta systems, the late Devonian Catskill delta complex (Figures 5 and 6) and the early Mississippian Price-Rockwell delta complex (Milici and Swezey, 2006).

During the late Devonian, five major fluvial-deltaic systems dominated the Catskill delta complex. These systems fluctuated (Figure 5, 6 and 7) in response to eustatic sea-level fluctuations, but due to the high rates of sedimentation prograded westward (Boswell and Donaldson, 1988). Muddy lobate shorelines that were dominated by fluvial-deltaic processes were produced, and deposited numerous sandstone and siltstone units, shale intervals, and red beds (Boswell and Donaldson, 1988; Milici and Swezey, 2006).

The Venango Group sandstone and siltstone units of the Catskill delta complex were deposited during the upper half of the Famennian Stage of the Devonian (Roen et al., 1996). During this stage, siliclastic sediments eroded off the western flanks of the Acadian mountains and were transported to sea by way of fluvial-deltaic systems. With increasing sediment influx and marine processes along the shoreline, marginal-marine 


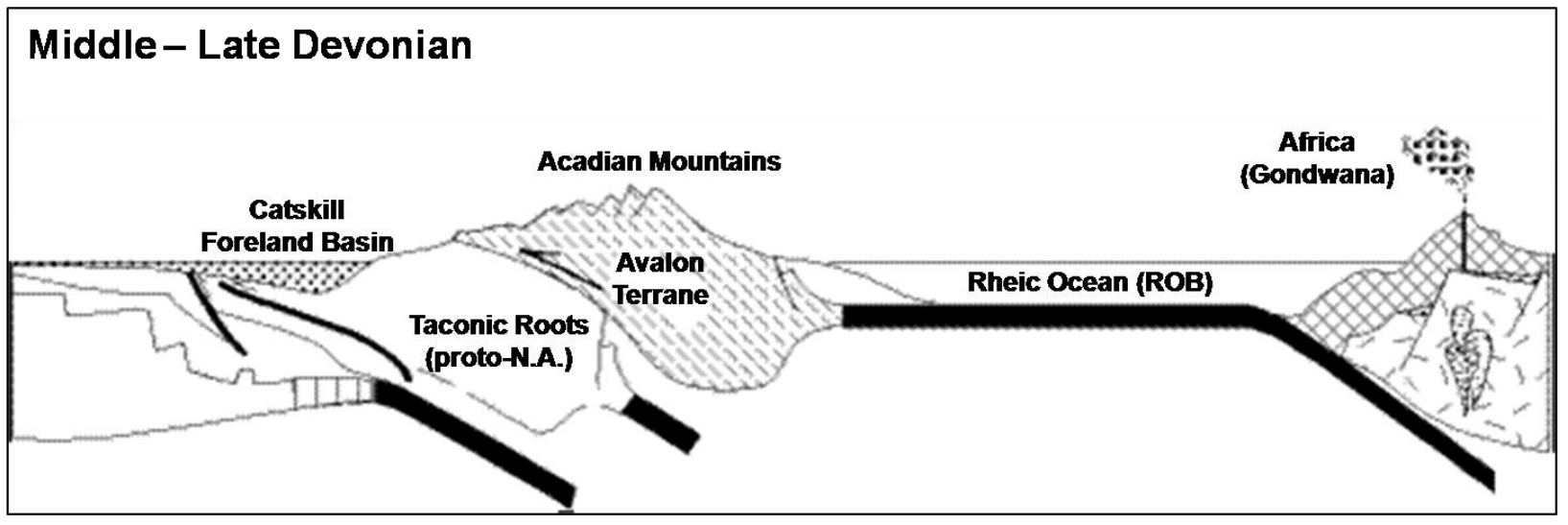

Figure 5. Structural cross-section illustrating the Devonian Acadian orogeny. The Upper Devonian sandstone units were deposited in the Catskill foreland basin (modified after Fichter, 1993). 


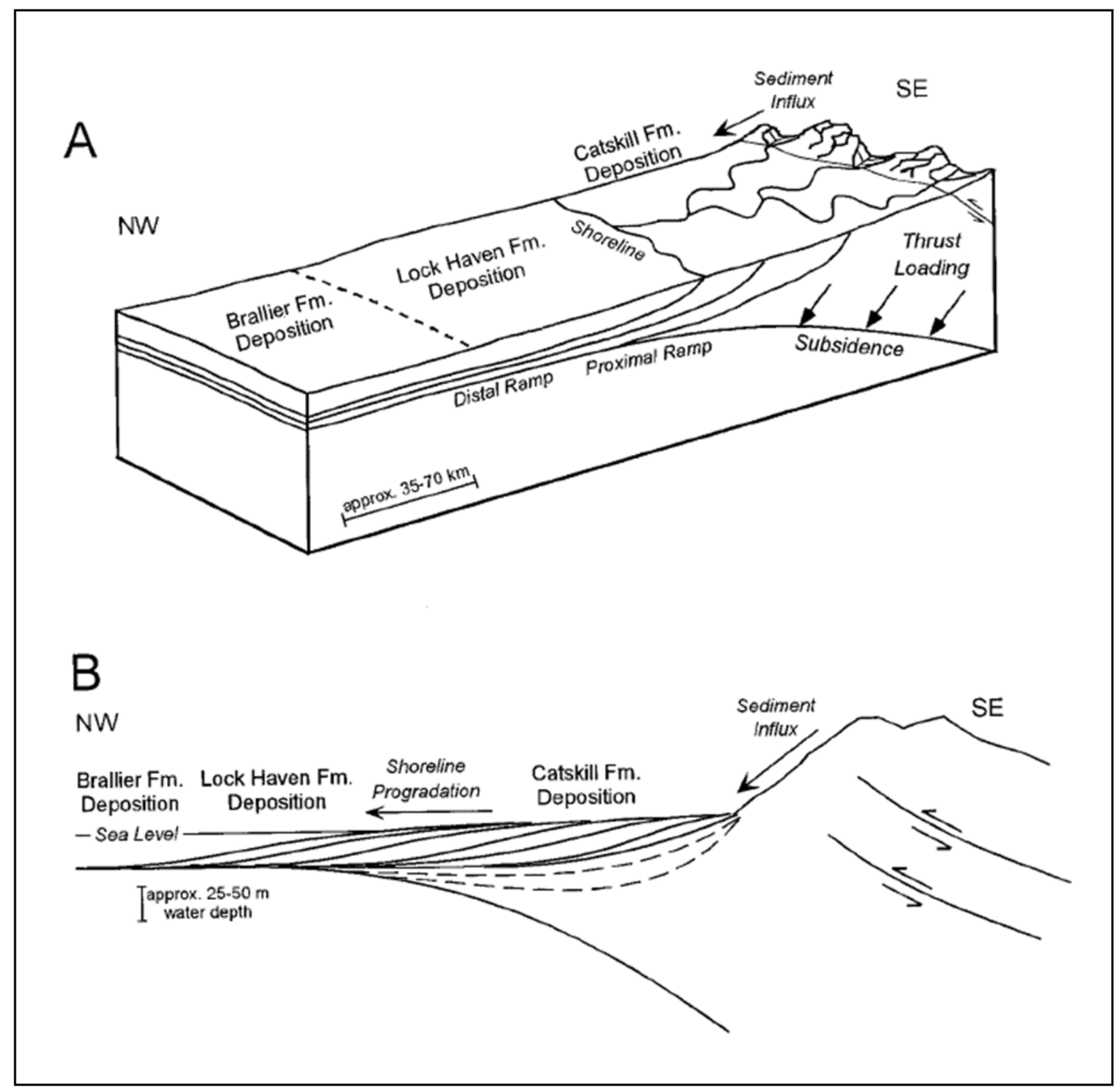

Figure 6. Image A illustrates a block model of the Catskill deposition in the Appalachian shallow foreland-ramp basin. Image B depicts a cross-section of shoreline progradation to the northwest related to the tectonic uplift to the southeast and increased sedimentation (modified after Castle, 2000). 


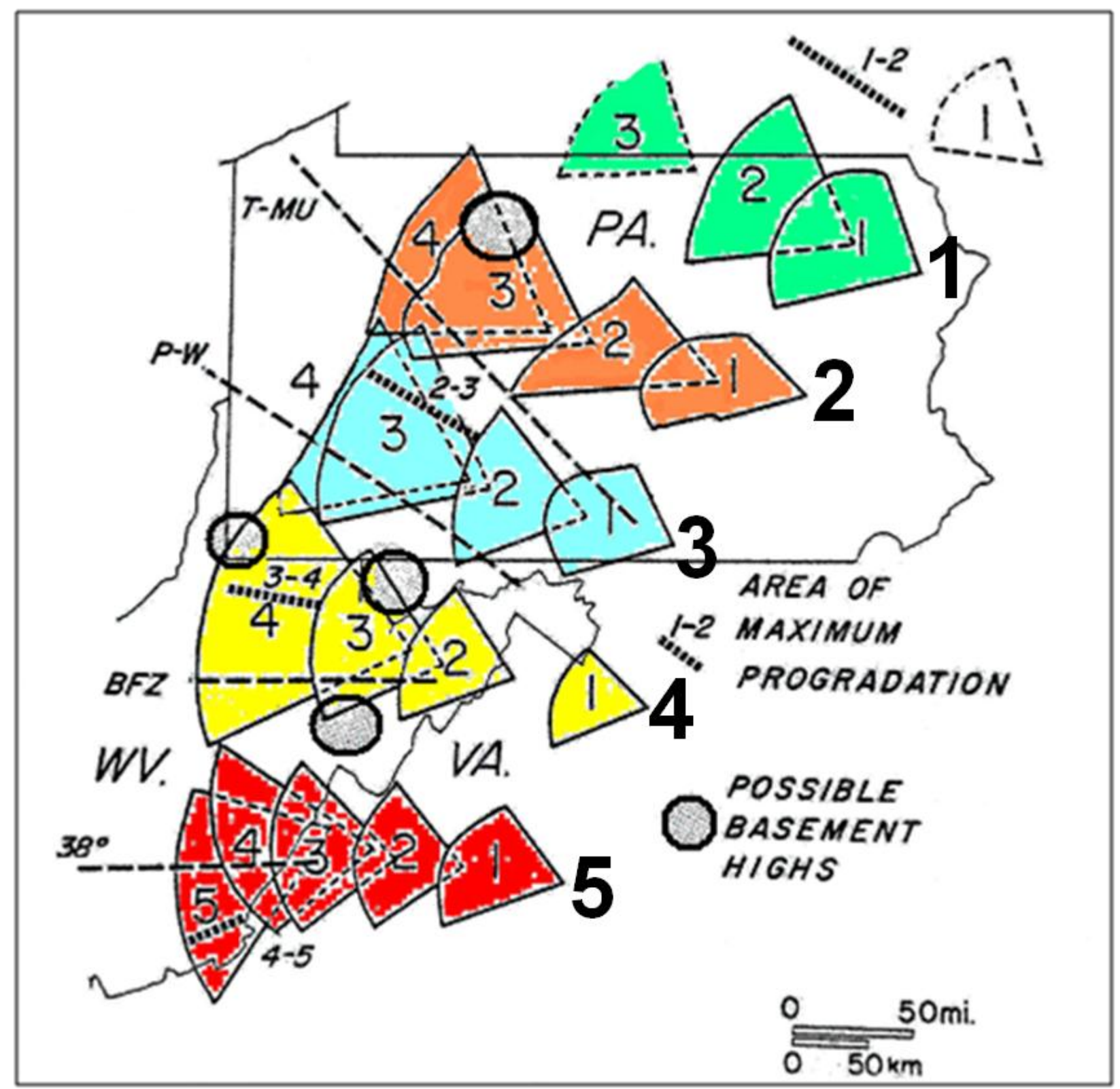

Figure 7. Upper Devonian fluvial-deltaic systems prograding to the northwest. The study in Taylor County is located near the area of maximum propagation for lobe 4 (shaded in yellow) in northern West Virginia (modified after Boswell and Jewell, 1988). 
sediments became reworked and relatively sandstone rich (Boswell and Donaldson, 1988; Boswell and Jewell, 1988). The Venango Group sandstone and siltstone reservoirs formed in a wide variety of paleoenvironments at the close of the Catskill deposition. Various marine and non-marine depositional environments that have been described include; fluvial, deltaic, interdeltaic, shoreline, shelf, and slope (Roen et al., 1996). 


\section{RESERVOIR GEOLOGY}

Natural gas production from the Upper Devonian Venango Group extends across the Appalachian basin from southern West Virginia to north-central Pennsylvania. The Venango reservoirs display a wide variety of trends and sandbody geometries that were formed by the episodic reworking of sediments under fluctuating fluvial and marine processes in conjunction with eustasy, and high but widely varying sedimentation rates (Boswell and Donaldson, 1988; Roen et al., 1996). These variations in sea level and sediment supply result in different marine and non-marine depositional patterns along a shallow foreland-ramp shoreline (Figure 8) (Roen et al., 1996). Boswell and Jewell (1988) observed and differentiated localized strike and dip depositional trends for the Venango Group reservoirs across northern, central, and southeastern West Virginia. The localized strike and dip trends were interpreted as fluvial-deltaic sandstone units formed along shorelines with lobate morphologies (Boswell and Jewell, 1988).

The Middle and Upper Devonian black-shale units found above, below, and interbedded with the Venango sandstone, and siltstone reservoirs are interpreted as the principal source of gas (Milici and Swezey, 2006). Trapping mechanisms are primarily stratigraphic or combination stratigraphic-structural traps (Roen et al., 1996; Milici and Swezey, 2006). The influence of structure on production is nominal; although, there is evidence that underlying basement structures influenced the distribution of reservoir facies. Vertical stacking of the Venango Group sandstone and siltstone units in central West Virginia and southwestern Pennsylvania has been attributed to differential subsidence along basement faults (Bowell et al., 1996). Seals for these reservoirs include interbedded shale beds and fine-grained siltstone intervals and the extensive 


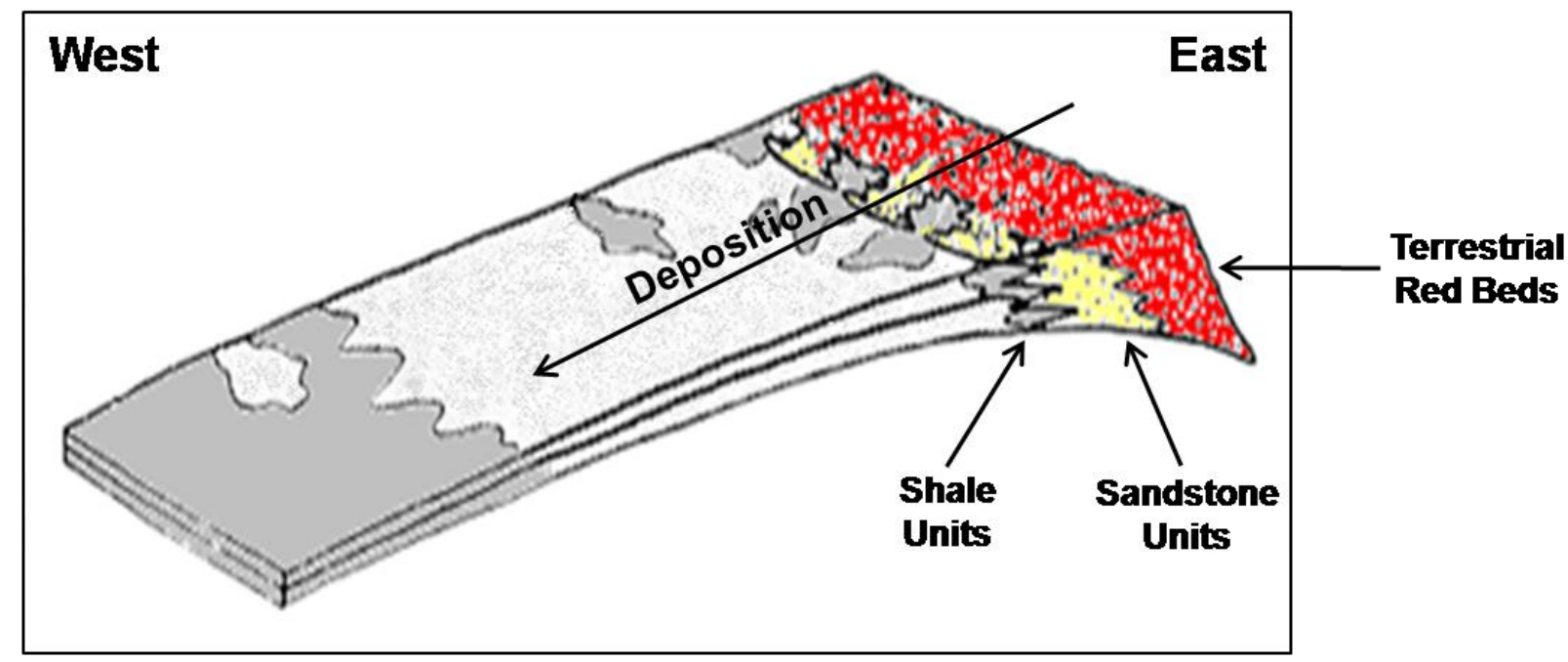

Figure 8. Idealized depositional model of the Upper Devonian Venango Group into a shallow foreland-ramp basin, northern West Virginia (modified after Boswell and Donaldson, 1988). 
overlying Upper Devonian shale (Ryder, 1995; Milici and Swezey, 2006). Gas generation and migration into the Venango Group reservoirs has been interpreted to initiate between the late Mississippian to early Triassic as siliclastic sediments buried the Catskill deposition during the Alleghenian orogeny (Rowan et al, 2004; Rowan, 2006; Milici and Swezey, 2006).

The Venango reservoirs typically have a depth of approximately 3,500 feet $(1,067 \mathrm{~m})$ in West Virginia to less than 1,000 feet $(305 \mathrm{~m})$ in Pennsylvania. Total reservoir thickness can reach up to 200 feet $(60 \mathrm{~m})$ with individual sandstone thickness between 15 to 20 feet $(4.5$ to $6 \mathrm{~m}$ ). Primary porosity is commonly intergranular and ranges between 18 to 25 percent (Roen et al., 1996). However, mechanical compaction, burial diagenesis, and pore-filling materials such as calcite, silica, and clay minerals can reduce intergranular porosity (Milici and Swezey, 2006). Typical permeability values are 10 to $100 \mathrm{md}$, but some values can reach over $1000 \mathrm{md}$ (Roen et al., 1996). The most productive Venango reservoirs are found along elongated series of northeast to southwest trends, in zones of greater porosity. To the west, reservoir quality quickly decreases as shale increases and sandstone units become more immature, and cemented (Boswell and Jewell, 1988; Roen et al., 1996). 


\section{METHODOLOGY}

A review of literature from previous work on the Upper Devonian sandstone and reservoirs in northern West Virginia provided a foundation of methods and materials, and a basic stratigraphic framework to investigate the Fourth Sand. In addition, the previously defined general subsurface position and log signature of the Fourth Sand in northern West Virginia was used to assist in correlation of the reservoir unit across the study area.

To begin identifying and correlating the Upper Devonian Fourth Sand units across the study area, a representative correlation type log was constructed using gamma-ray, deep resistivity, neutron porosity, bulk density and density porosity (2.73 $\mathrm{g} / \mathrm{cm}^{3}$ ) log curves (Figure 9). Petroleum Development Corporation Williams-560 was selected as the primary correlation type log for the study area because it illustrates a complete interval of sediments representative of the Fourth Sand reservoir. A network of 54 detailed and systematic cross-sections were constructed by using a network of strike-dip and loop cross-sections anchored to the correlation type log in order to maintain identification consistency (Figure 10). Gamma-ray cutoffs and significant marker beds were used in identification and correlation of the Fourth Sand. Previous stratigraphic studies related to the Upper Devonian Venango Group used a gamma-ray cutoff of $80 \mathrm{API}$ for sandstone reservoirs; however, for this project a gamma-ray cutoff of $90 \mathrm{API}$ was used because of the more argillaceous nature of the Fourth Sand in the study area. A Fourth Sand low-resistivity (10 - 15 OHMS) log signature in conjunction with an approximate porosity range of 6 to 10 percent (if present) was also used to identify reservoir quality sands. 


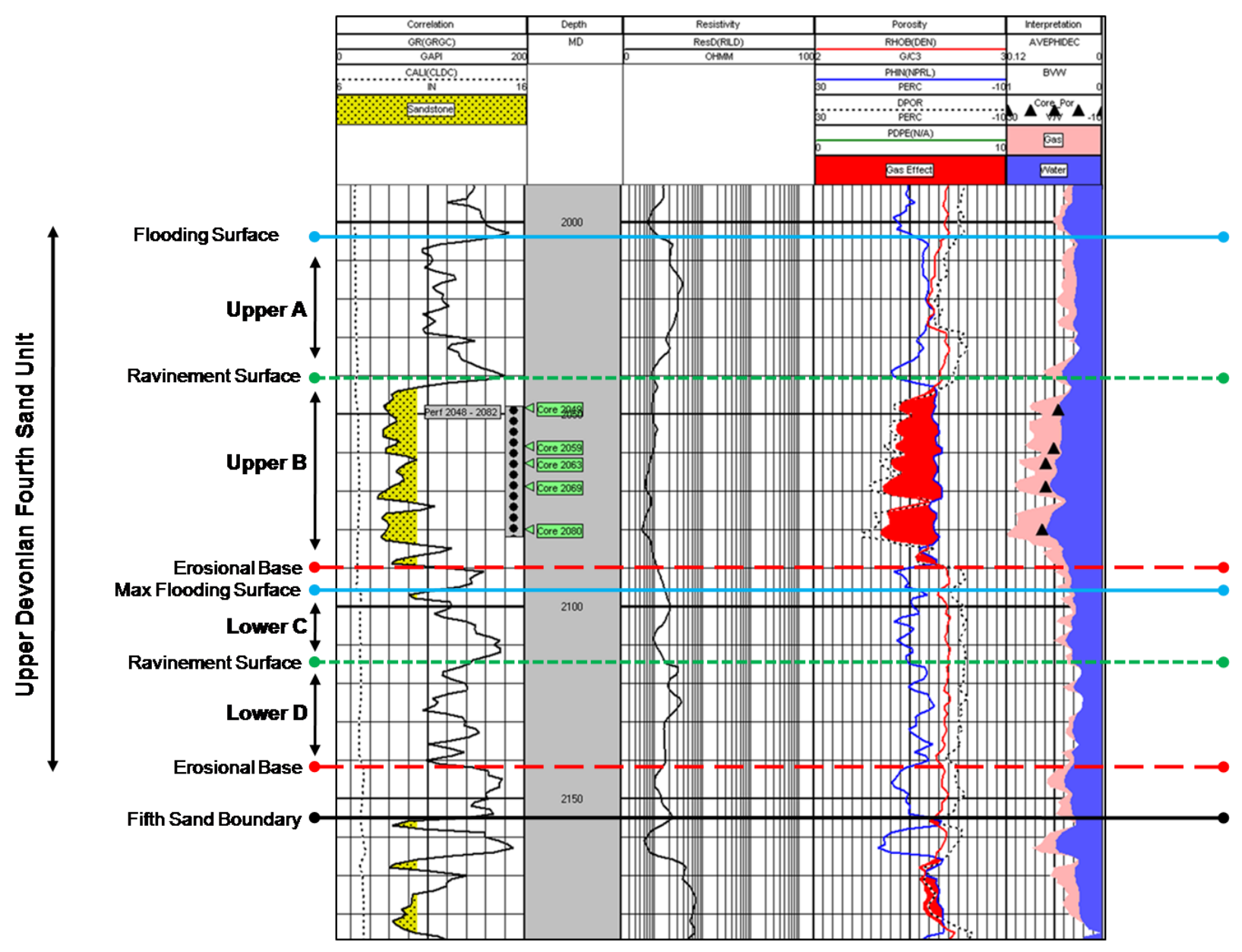

Figure 9. Correlation type log: Petroleum Development Corporation Williams-560. Gamma-ray (cutoff of $90 \mathrm{API}$ ), deep resistivity, bulk density, density porosity (2.73 $\mathrm{gm} / \mathrm{cm}^{3}$ ), and neutron porosity digital-log curves are displayed in tracks 1,2 , and 3 . Cross-over of the density and neutron porosity curves is highlighted in red and indicates the presence of gas. Interpretation of bulk volume water (blue) and hydrocarbon saturation (pink) is illustrated in track 4. Perforation interval is shown in track 1. Reported porosity from core plugs is illustrated in track 4 and show general agreement with porosity. One rotary sidewall core with accompanying core data is located at a depth of 2080 feet (Location of the type log-core well is displayed in Figure 2). Mapped and interpreted horizons are shown to the left and in subsequent sections defined and discussed. 


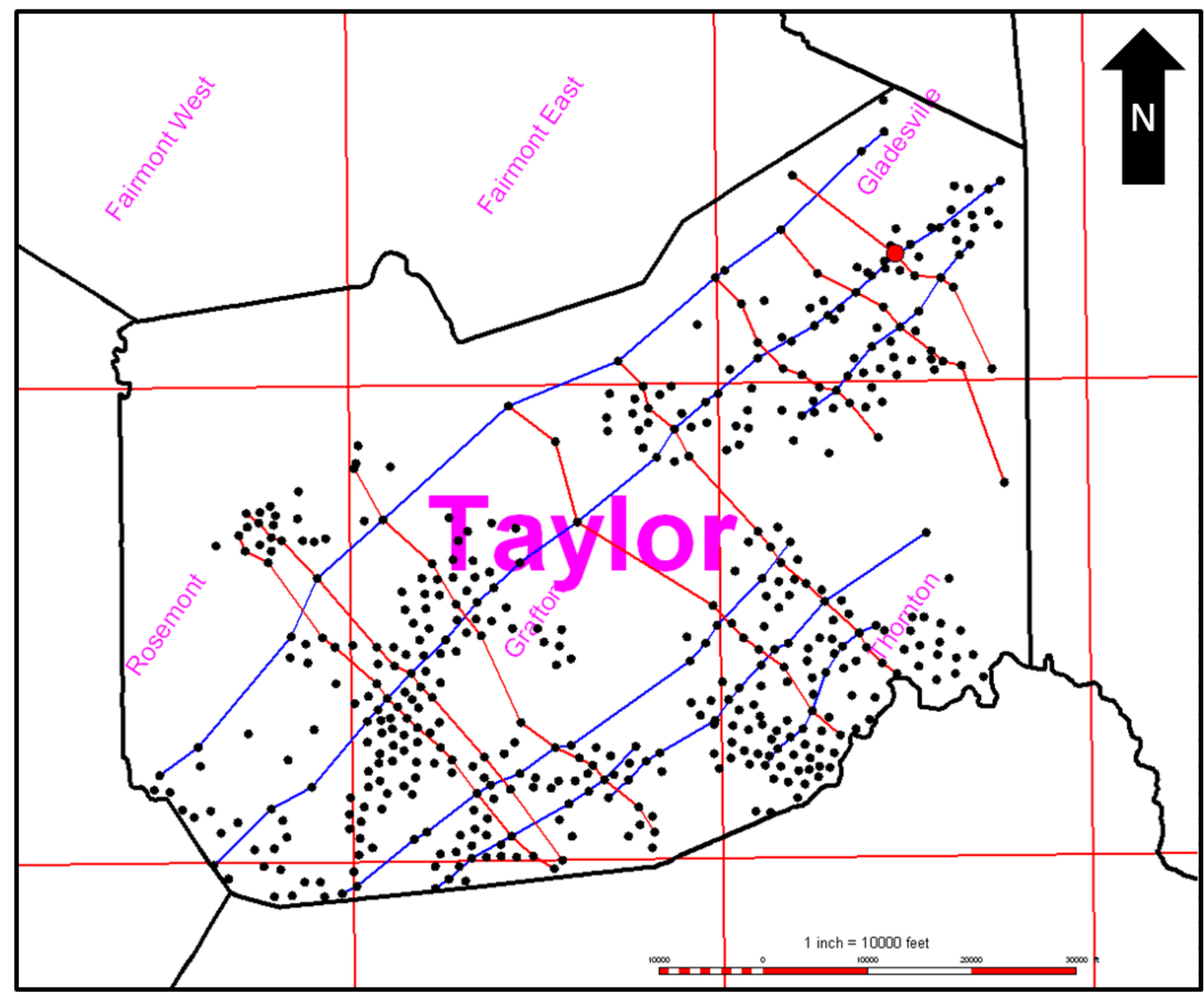

Map Legend

Well Location

Type Log-Core Plug

Strike Cross Sections

- Dip Cross Sections

Figure 10. Base map illustrating the network of strike and dip cross sections constructed, and used to correlate the Fourth Sand across the study area. 
Supplementary structure and isopach regional maps were generated in an attempt to illustrate the external architecture of the Fourth Sand reservoir units. Additional attribute maps were constructed by highlighting zones of interest and converting the saved zone data into isomap layers. Attribute maps produced include gross sand, net sand, and the degree of cross-over between density porosity and neutron porosity curves. A minimum curvature algorithm was used to build all isomap layers.

Detailed log analyses and interpretation was undertake on selected wells with sufficient data to provide estimates of fluid (gas and formation water), lithology, and other petrophysical parameters that are used to improve our understanding of the spatial distribution of the Fourth Sand reservoir unit and adjacent non-reservoir units. Other petrophysical parameters evaluated include average porosity, gas effect, bulk volume water, and water saturation. To overcome the lack of digital-log data available in the study area, raster logs were digitized in order to broaden the coverage of the digital database.

The Archie Equation, saturation crossplots, and bulk volume water were used to calculate and estimate fluid saturations. The Archie Equation calculates a reservoir's water saturation $(S w)$ by utilizing two primary variables: resistivity $(R t)$ and porosity $(\varnothing)$ into the following equation (Asquith and Krygowski, 2004):

$$
S w=\left[\left(\frac{a}{\emptyset^{m}}\right) X\left(\frac{R w}{R t}\right)\right]^{\frac{1}{n}}
$$

where:

$$
\begin{aligned}
& S w=\text { water saturation } \\
& \emptyset=\text { porosity }
\end{aligned}
$$




$$
\begin{aligned}
& R w=\text { formation water resistivity } \\
& R t=\text { observed bulk resistivity (true resistivity) } \\
& a=\text { a constant }(1.65 \text { after Carothers, } 1968) \\
& m=\text { cementation factor (1.33 after Carothers, 1968) } \\
& n=\text { saturation exponent ( } 2.0 \text { after Carothers, 1968) }
\end{aligned}
$$

Porosity values were obtained from well logging tools from which an average porosity $(\emptyset)$ value was calculated via the sum of density porosity $(D P O R)$ and neutron porosity $(N P R L)$ divided by 2 :

$$
\emptyset=\frac{D P O R+N P R L}{2}
$$

Average porosity was calculated to balance the gas effect on the density porosity in relatively clean (clay-free) porous sandstone and the effect of clay bound water on the neutron porosity in relatively clay-rich (dirty) less porous sandstone.

Saturation crossplots were constructed using the Pickett crossplot (Figure 11) method, a graphical representation of the Archie Equation. The Pickett crossplot is based on the function of true resistivity $(R t)$, porosity $(\emptyset)$, water saturation $(S w)$, and cementation $(m)$ exponent variables. This technique utilizes the basic line equation $(y=m x+b)$. True resistivity $(R t)$ is plotted on the $y$-axis (on a logarithmic scale) against average porosity $(\varnothing)$ on the $x$-axis (on a logarithmic scale) from which determines the product $(R w X a)$ from intercept of the line $(b)$, and cementation exponent $(m)$ from the slope of the line $(m)$. Formation water resistivity $(R w)$ can be estimated, from the water-bearing ( $100 \%$ water) line. Plotting a zone of water and hydrocarbon-bearing data points, water-bearing points plot parallel to the water line, 


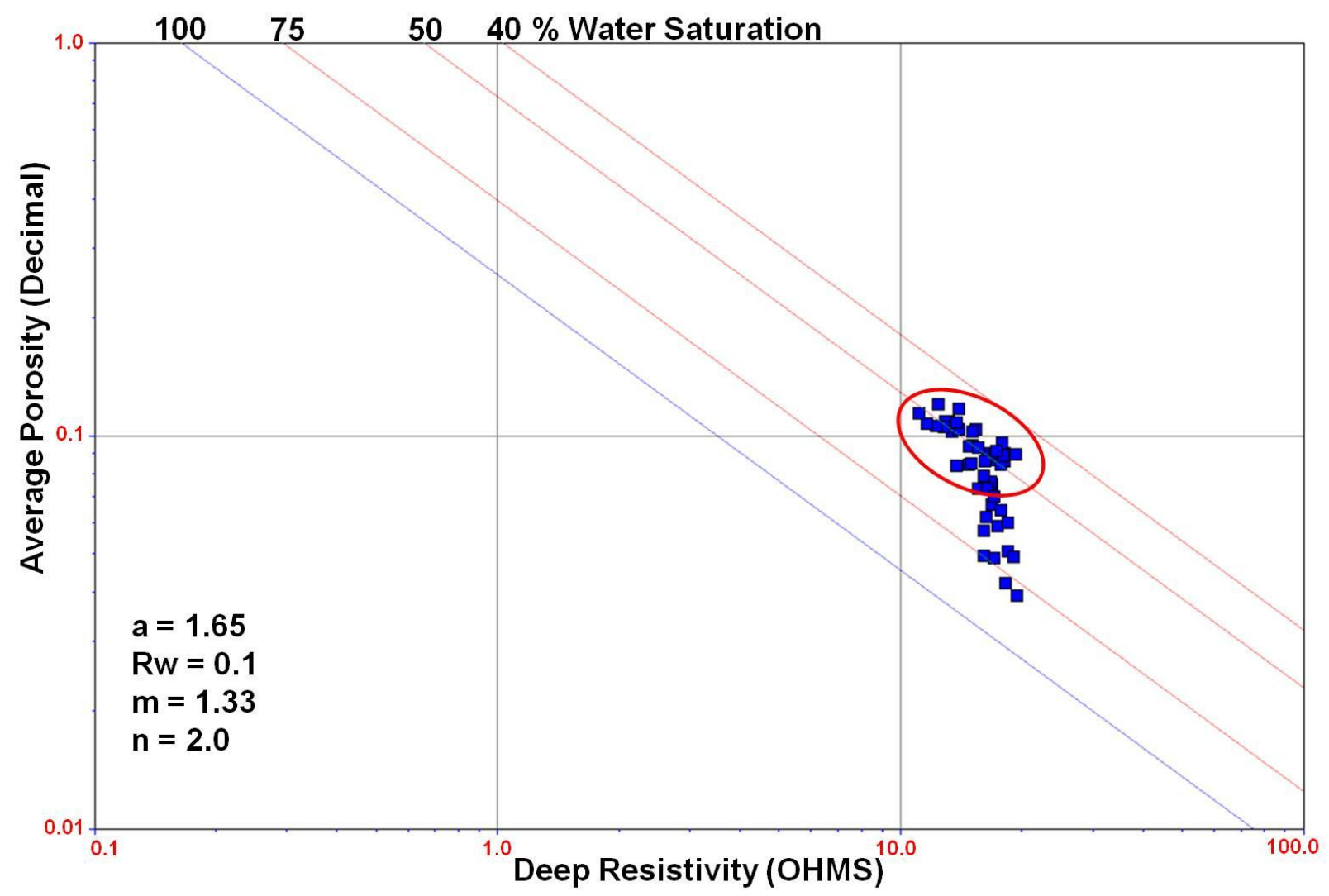

Figure 11. Pickett plot of type log Petroleum Development Corporation Williams-560 showing the hydrocarbon-bearing zone (circled in red) in the depth interval $2041-2089$ feet. The points trailing downward forming a vertical pattern indicating that the change in saturation is a result of a decrease in porosity below levels that can contain hydrocarbons. 
whereas hydrocarbon-bearing points plot a distance away from the water line because of their increased hydrocarbons and decreased water saturation value (Asquith and Krygowski, 2004). Shallow gas reservoirs with a $50 \%$ or more hydrocarbon saturation are commonly targeted in the Appalachian basin. Pickett plot parameters $(a, m$, and $n)$ were selected for shaley sands because of the argillaceous nature of the Fourth Sand (after Carothers, 1968).

Bulk volume water $(B V W)$ is the product of a formation's water saturation $(S w)$ and its porosity (Ø) (Asquith and Krygowski, 2004):

$$
B V W=S w X \emptyset
$$

If bulk volume water values are constant throughout a formation of interest, they indicate that the zone is a single rock type and is at irreducible water saturation. Water in an irreducible water saturation zone does not move because it is held under capillary pressure by grains or is bound to clay minerals; thus, initial produced hydrocarbons would be water free (Morris and Biggs, 1967; Asquith and Krygowski, 2004). Bulk volume water and average porosity calculations were used to construct an interpretative log curve illustrating the relative percentage of water and hydrocarbons (Figure 9). In the reservoir unit, the bulk volume water remains relatively constant and suggests that the reservoir unit will have interval water-free production.

Density-neutron crossplots were used to construct basic lithologic descriptions of a formation by way of using mineral endpoints and porosity. Porosity values were derived from density and neutron well logging tools. The neutron log is a porosity tool 
that measures the amount of hydrogen in a formation and the density log measures electron density, as well as formation bulk density (Asquith and Krygowski, 2004). Density-neutron crossplots determine the difference between a mixture of dolomite and sandstone or dolomite and limestone in a formation, as well as the presence of hydrocarbons in a zone. Density-neutron crossplots were generated for the type log within the study area in order to have a general interpretation of the lithology

Mineral identification crossplots or RHOmaa-Umaa crossplots were used to indicate a formation's lithology in conjunction with the one rotary sidewall core XRD, mineralogy, and relative clay abundances data. RHOmaa-Umaa (Umaa vs. $\rho m a a$ ) crossplots use an apparent matrix density ( volumetric cross section (Umaa) in barns $/ \mathrm{cm}^{3}$. Umaa is calculated from the following matrix identification equation (Asquith and Krygowski, 2004):

$$
U m a a=\frac{(P e X \rho b)-(\emptyset N D X U f l)}{1-\emptyset N D}
$$

where:

$$
\begin{aligned}
& \text { Umaa = apparent volumetric cross-section in barns/electron } \\
& P e=\text { photoelectric absorption in barns/electron } \\
& \rho b=\text { bulk density } \\
& \emptyset N D=\text { neutron-density porosity } \\
& U f l=\text { photoelectric absorption of fluid }
\end{aligned}
$$

Umaa and $\rho m a a$ values (Schlumberger, 2009) for different minerals can be obtained from the matrix identification equation (Asquith and Krygowski, 2004). Quartz, dolomite, and calcite are the most common mineral endpoints used for sedimentary rocks; however, a variety of endpoints can be chosen. For this study, quartz, feldspar, and 
illite mineral endpoints were chosen for the RHOmaa-Umaa crossplots because they were the most abundant minerals observed in the rotary sidewall core data.

The one rotary sidewall core (2080 feet depth) provided lithologic data to calibrate RHOmaa-Umaa crossplots and indicate that quartz, feldspar, and illite as endpoints. The selected correlation type log for the study area where the sidewall core was also obtained does not contain a $P e$ log cure, so RHOmaa-Umaa crossplots could not be generated for this well. Crossplots were generated for neighboring wells that contained the appropriate suite of log curves in order to determine if the Fourth Sand lithology was consistent with the minerals observed in the core data. The sidewall core also provided material for a thin section to examine and confirm mineralogy determined by the RHOmaa-Umaa crossplots. Lithologic analyses provide insight on the apparent argillaceous nature and low-resistivity of the Fourth Sand reservoir. 


\section{DESCRIPTION AND INTERPRETATION OF THE FOURTH SAND UNITS}

Wilson and Nanz (1959) developed a log classification system of log curve shapes by the self-potential (SP) log, which is applied to the gamma-ray log. Characteristic shapes were interpreted to reflect lithologic properties, which were a function of the depositional origin of a sandbody. Descriptive log curve shapes are classifed on the basis of (1) degree of interbedding and (2) nature of sandstone-shale contacts. A smooth curve is interpreted as a sandstone unit with few or no shale interbeds, and a serrate curve as a sandstone unit consisting of interbedded sandstone and shale. A sharp sandstone-shale contact is represented by an abrupt change in the log curve and a gradual change from sandstone to shale is marked by a progressive decrease in the log curve reflection (Wilson and Nanz, 1959).

A further simplified descriptive classification system of SP log curve shapes incorporates bell, funnel, and cylinder-shapes. A bell-shaped log curve depicts a vertical sequence of decreasing grain size and thickness of interbeds upward from an abrupt lower contact. A funnel-shaped log curve is a sandbody with an increasing grain size and thickness of interbeds with an abrupt upper contact. A cylinder-shaped log curve indicates no systematic change in grain size or thickness of interbeds with abrupt upper and lower contacts (Wilson and Nanz, 1959).

The classification of log curve shapes has been used in interpreting the lithology and depositional origin of sand. For this study, the gamma-ray (GR) log was used for interpreting log curve shapes. The GR log can be applied to Wilson and Nanz (1959) SP classification system, because both log tools measure lithology differences between sandstone and shale. Sharp sandstone-shale contacts indicated by an abrupt change 
in the gamma-ray log provide a method to subdivide the Fourth sandstone interval into four sand-rich units.

The four sandbodies of the Fourth sandstone unit were correlated across the study area. These four sandbodies were separated by abrupt sandstone-shale marker beds, which were interpreted following a sequence stratigraphic model as erosional base surfaces, ravinement surfaces, and maximum flooding surfaces. The four sandbodies are defined into upper sand-rich units (Upper A and Upper B) and lower sand-rich units (Lower C and Lower D) (Type log in Figure 9). The following four sandbodies are described and interpreted based on log response, correlated throughout the study area and constructed isopach and gross sand maps.

\section{Upper A Fourth Sand}

The Upper A Fourth Sand is a serrated, funnel-shaped sandbody (Figure 12). The sand illustrates a high gamma-ray reading and a coarsening upwards log signature with a sharp upper contact, and gradational lower contact. The Upper A Fourth Sand displays a low porosity with a limited or no presence of hydrocarbons suggesting low permeability. The presence of sandstone and shale interbeds in the Fourth Sand is typically associated with lower reservoir quality.

The Upper A Fourth Sand density-neutron and RHOmaa-Umaa crossplots indicate a calcite (limestone), clays (illite), and quartz as prominent lithic components

(Figures 13 and 14). The Upper A Fourth Sand isopach map illustrates a weak northeast-southwest strike-trending lobate geometry with a generalized shorelines interpreted as oriented along strike of the basin (Figure 15). Distribution is widespread 


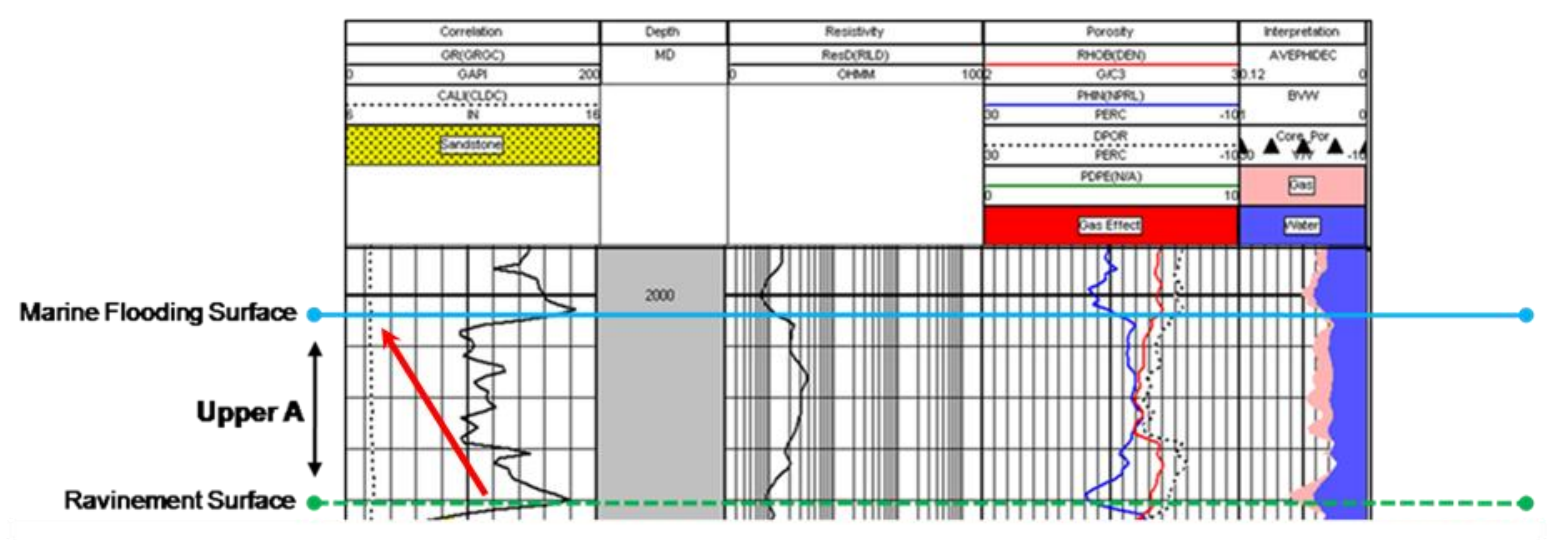

Figure 12. Upper A Fourth Sand Type Log: Petroleum Development Corporation Williams-560. The Upper A sandbody has a serrated, funnel-shaped log signature with a coarsening (cleaning) upwards pattern (red arrow) and sharp upper surface (interpreted flooding surface). 
TAY-560 Upper A Fourth Sand 2004-2041FT

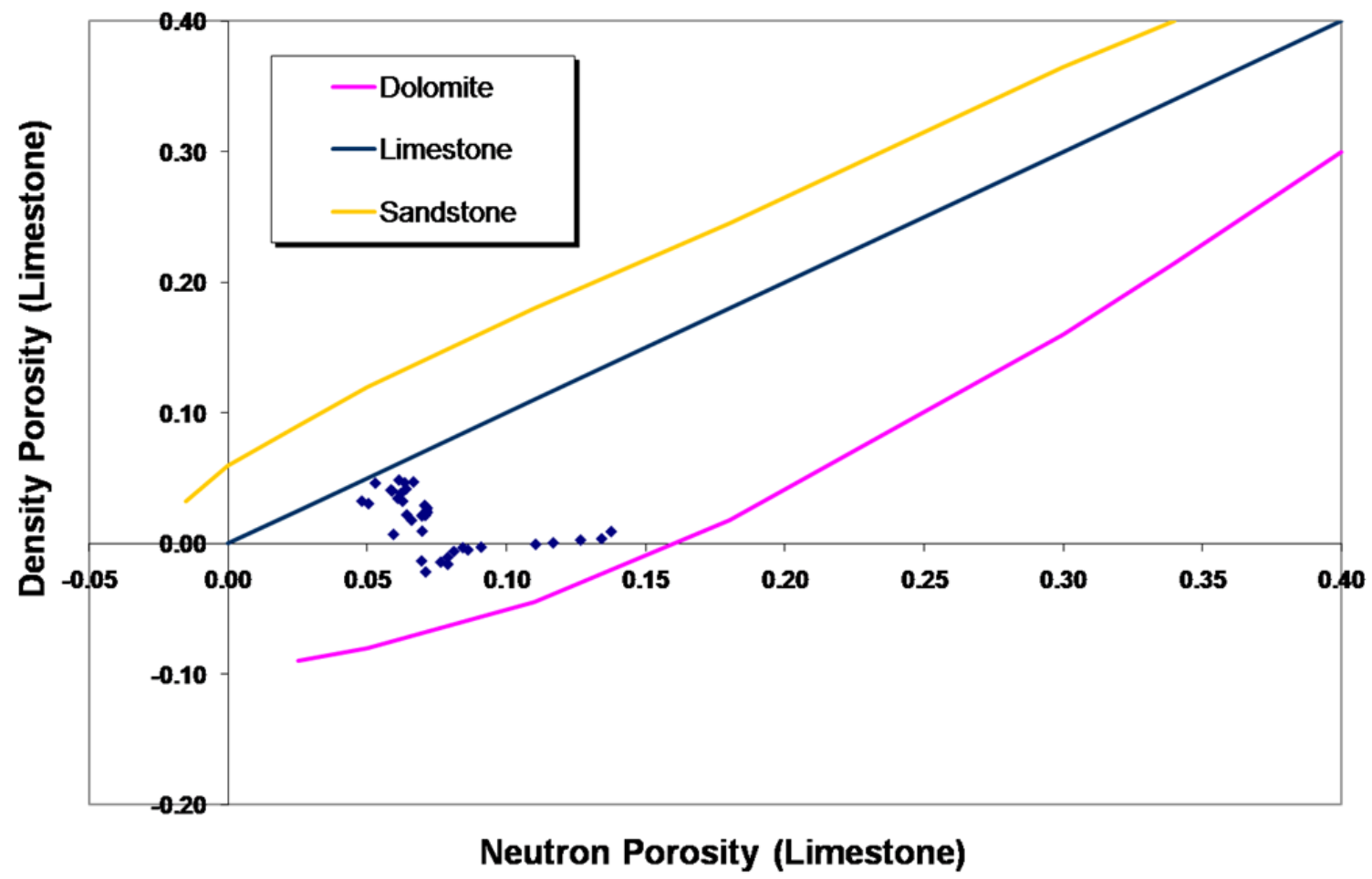

Figure 13. Upper A Fourth Sand density-neutron lithology crossplot for type log: Petroleum Development Corporation Williams-560. The plot indicates that the interval may contain significant carbonate (limestone) component, and has a relatively low porosity interval $(<5 \%)$. The horizontal trend along the zero percent density porosity, indicated by increased apparent neutron porosity is related to increase shale content. 


\section{TAY-808 Upper A Fourth Sand 2485-2505FT}

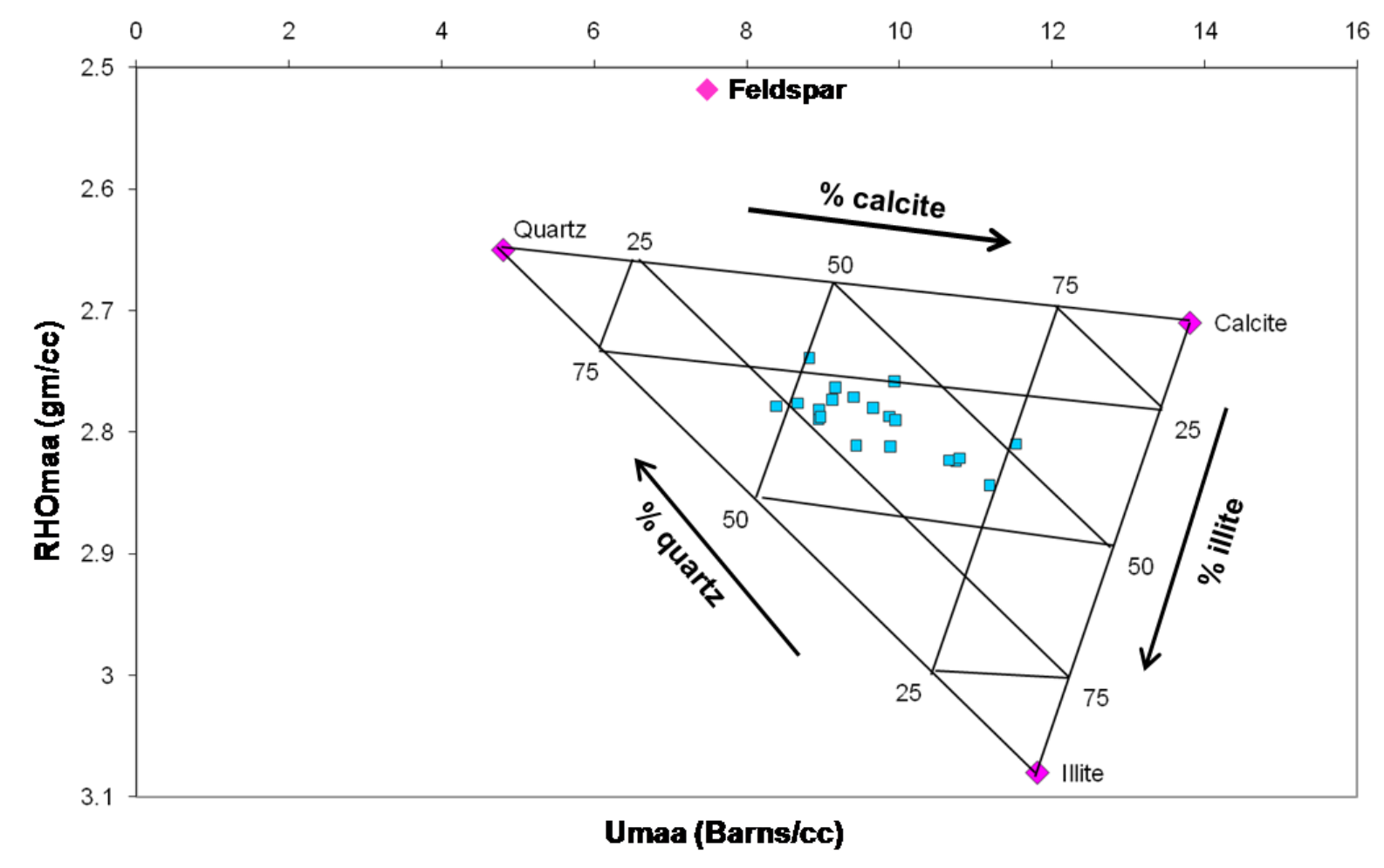

Figure 14. Upper A Fourth Sand RHOmaa-Umaa mineralogy crossplot for log: Petroleum Development Corporation Frey-808. Prominent lithic components consist of calcite (limestone), clay (illite), and quartz. 


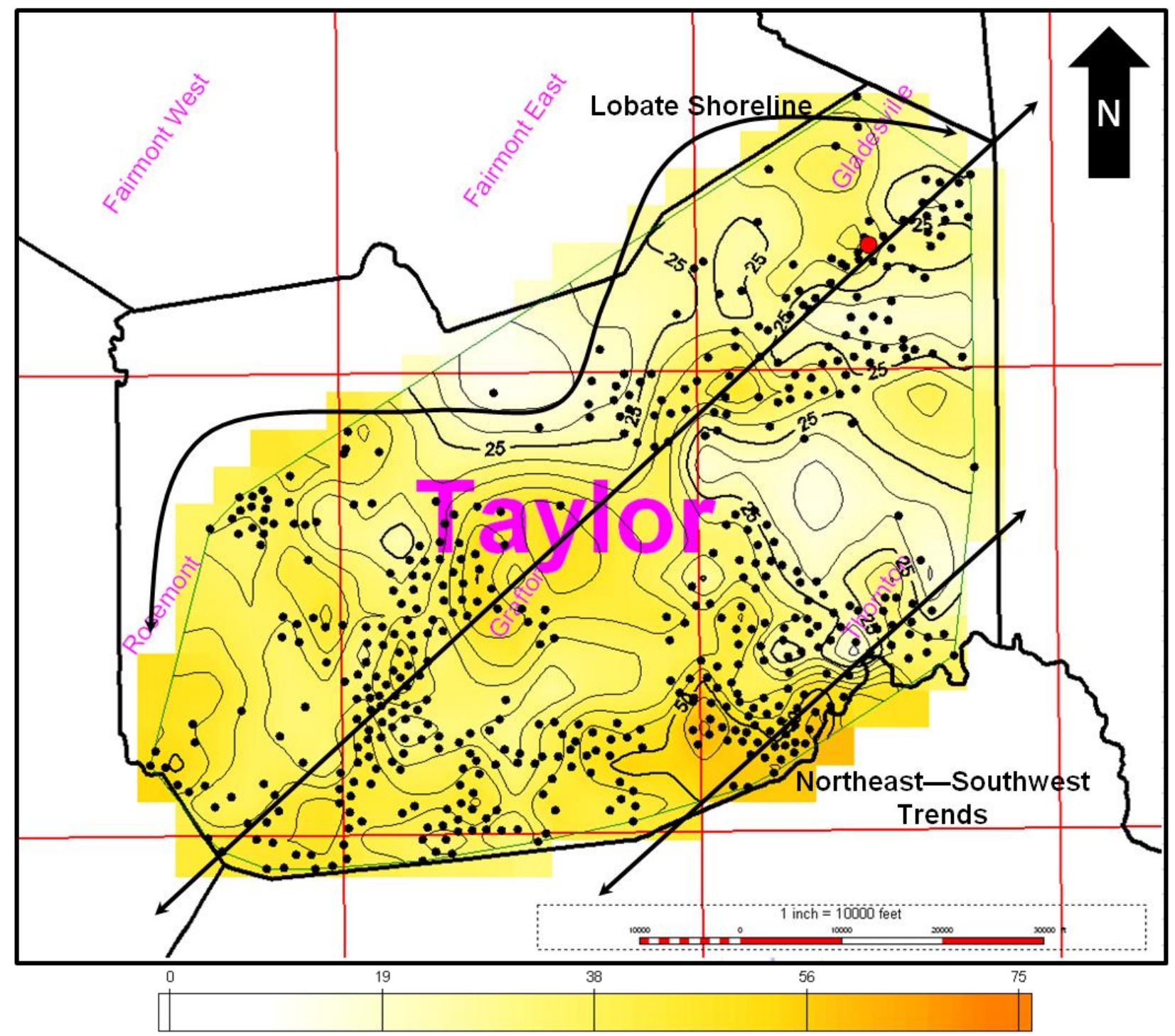

Map Legend

Well Location

Type Log-Core Plug

Figure 15. Upper A Fourth Isopach Map. Distribution is widespread with an average gross sand of 36 feet thick $(11 \mathrm{~m})$ across the study area. Lobate geometry of thick and thin areas define weak northeast-southwest trends defining a series of lobate shorelines along the strike of the foreland ramp basin. The maximum basin-ward shoreline of the Upper A Fourth Sand unit is interpreted to the northwest of the study area. Contour interval $(\mathrm{Cl})$ is 5 feet $(1.5 \mathrm{~m})$. 
across the study area, and relatively thick with an average gross sandstone of 36 feet $(11 \mathrm{~m})$, except for a few thin patchy areas toward the northwest. The maximum basinward shoreline of the Upper A Fourth sandstone unit is interpreted to the northwest of the study area.

Previously, the Upper A Fourth Sand has been interpreted as a argillaceous marine sandstone deposited along a muddy lobate shoreline across the shallow foreland-ramp basin (Boswell and Jewell, 1988). The serrated, funnel-shaped log pattern of coarsening (cleaning) upwards pattern observed on the gamma-ray with a sharp contact at the top supports the interpretation of the Upper A Fourth Sand as a prograding marine bar or shoreline unit (Wilson and Nanz, 1959). The sharp contact of the sandstone with the overlying shale is interpreted as a flooding surface. The densityneutron and RHOmaa-Umaa mineralogy crossplots indicate that this unit contains significant calcite and clay. The calcite may be attributed to marine fauna constituents that could contribute the calcite cement in the sandstone and relatively low porosity. The abundant clay is supported by the relatively high gamma-ray reading and serrated nature of the log cure.

\section{Upper B Fourth Sand}

The Upper B Fourth Sand shows a serrated, cylinder or blocky-shaped sandstone body (Figure 16). The sandbody has a low gamma-ray reading with a sharp lower and upper contact. The Upper B Fourth Sand displays a relatively high porosity (density porosity 10-20\%) and density, and neutron porosity log curves cross-over (shaded in red). When pore space is filled with hydrocarbons, the low density of the formation's hydrocarbons causes the calculated density to increase and neutron 


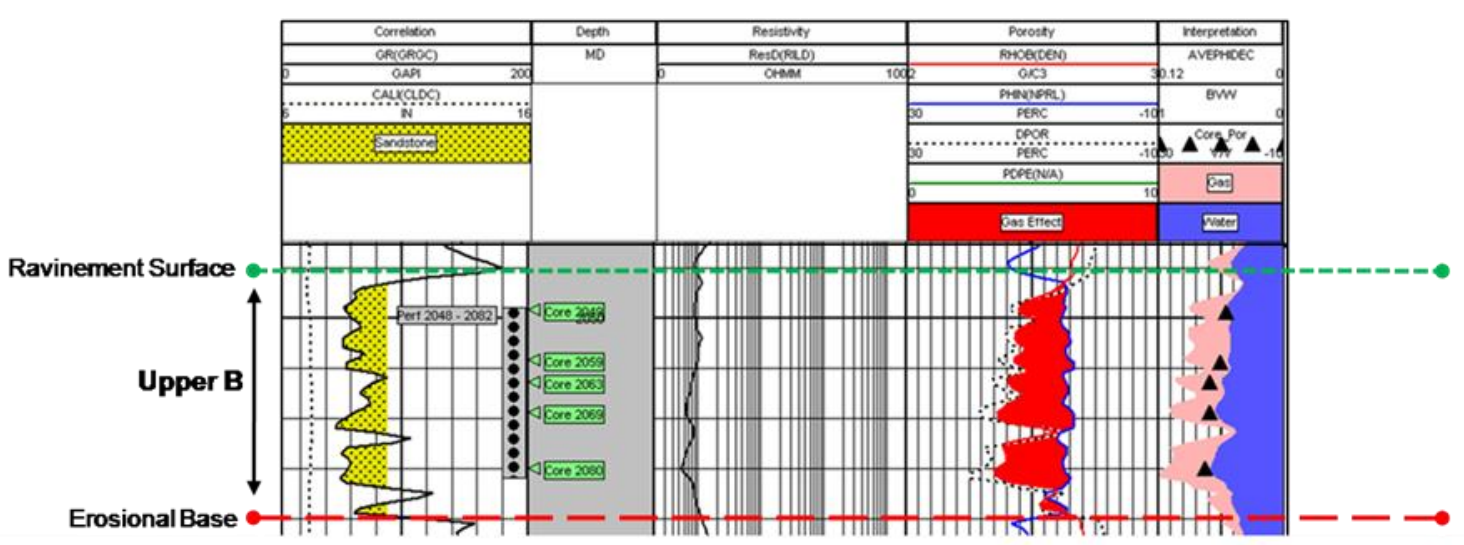

Figure 16. Upper B Fourth Sand Type Log: Petroleum Development Corporation Williams-560. The Upper B sandbody has a serrated, cylinder or blocky-shaped log signature with sharp lower and upper surfaces. Crossover of the density and neutron porosity curves (track 3 ) are highlighted in red and indicate the presence of gas, which is also evident in the interpretation track 4 . Core data (black triangles) plot on the average of density and neutron porosity (track 4), which also shows the computed hydrocarbon saturation. 
porosity to decrease. This process is known as the gas effect (Asquith and Krygowski, 2004). Reported core porosity from the rotary sidewall core plugs is in agreement with the average of the neutron and density porosity, which removes the gas effect.

The Upper B Fourth Sand density-neutron and RHOmaa-Umaa crossplots display a dominant quartz (sandstone), feldspar, and clay lithology (Figures 17 and 18). Data points located above the sandstone lithology line in the density-neutron crossplot indicate the presence of gas. The presence of gas is also in agreement with the gas effect and interpreted hydrocarbon saturation. Data points with very low density porosity drifting towards dolomite lithology line indicate the presence of clay, which is also depicted by the serrated nature of the gamma-ray log.

The Upper B Fourth Sand isopach map illustrates a northwest-southeast diptrending geometry of two thick areas separated by an area of thinner sandstone accumulation (Figure 19). However, the Upper B Fourth Sand is distributed is throughout the study area with an average gross sand thickness of 35 feet $(11 \mathrm{~m})$. The Upper B Fourth Sand has been interpreted as two fluvial-deltaic systems that once flowed and deposited toward a muddy lobate shoreline to the northwest (Boswell and Jewell, 1988). The serrated, cylinder or blocky log signature with sharp lower and upper surfaces along the dip orientation supports the fluvial-deltaic interpretation (Wilson and Nanz, 1959). The absence of calcite compared with the overlying Upper A Fourth Sand supports a non-marine or estuarine facies. The Upper B Fourth Sand density-neutron crossplot also indicates gas with data points located above the sandstone lithology line. The sharp boundaries of the Upper B Sand are interpreted as an erosional base and 
TAY-560 Upper B Fourth Sand 2041-2089FT

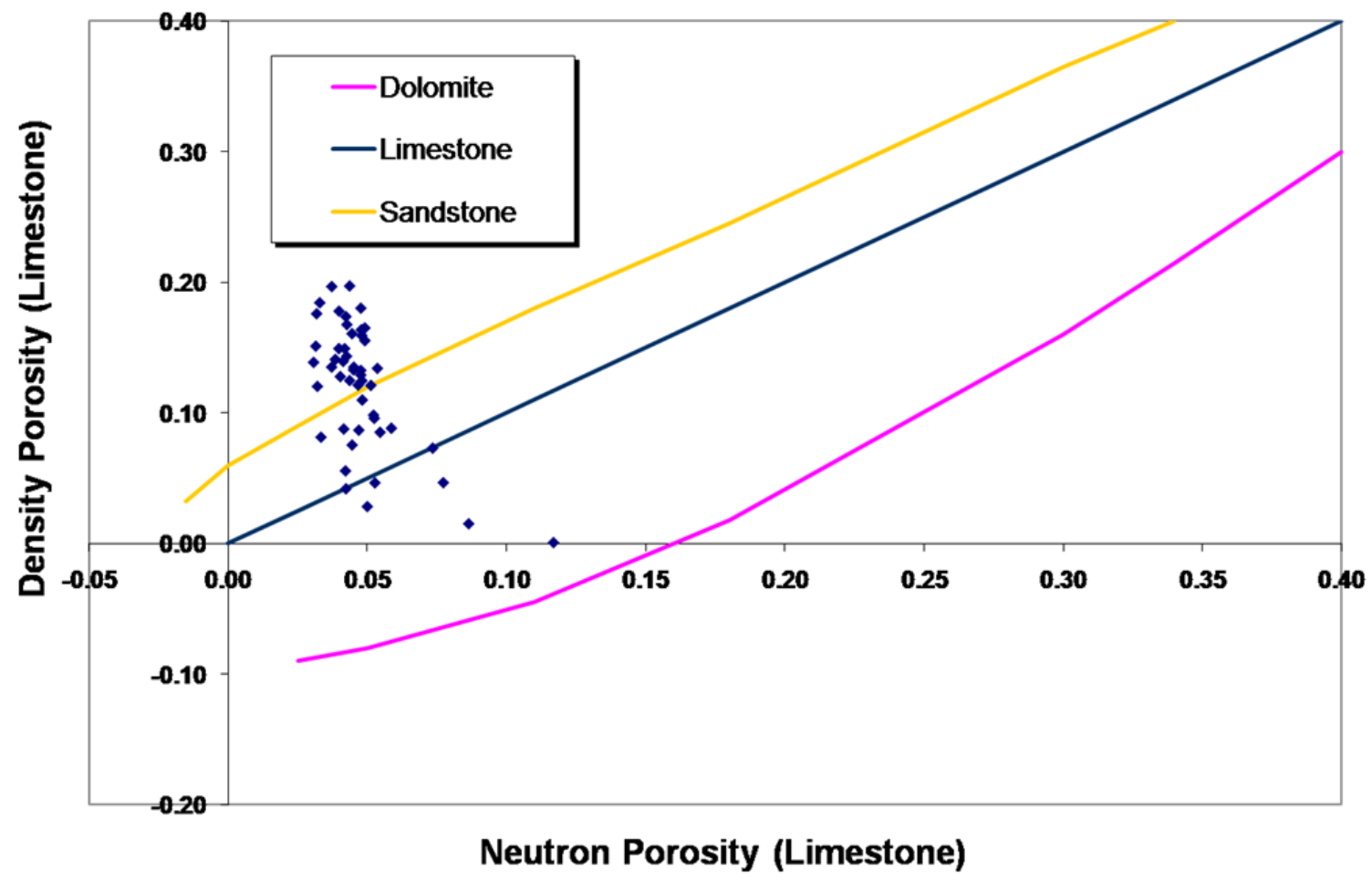

Figure 17. Upper B Fourth Sand density-neutron lithology crossplot for type log: Petroleum Development Corporation Williams-560. Data points located above the sandstone lithology line indicates the presence of gas and data points with low density porosity drifting to increased neutron porosity indicate the increased presence of clay. 
TAY-808 Upper B Fourth Sand 2504-2526FT

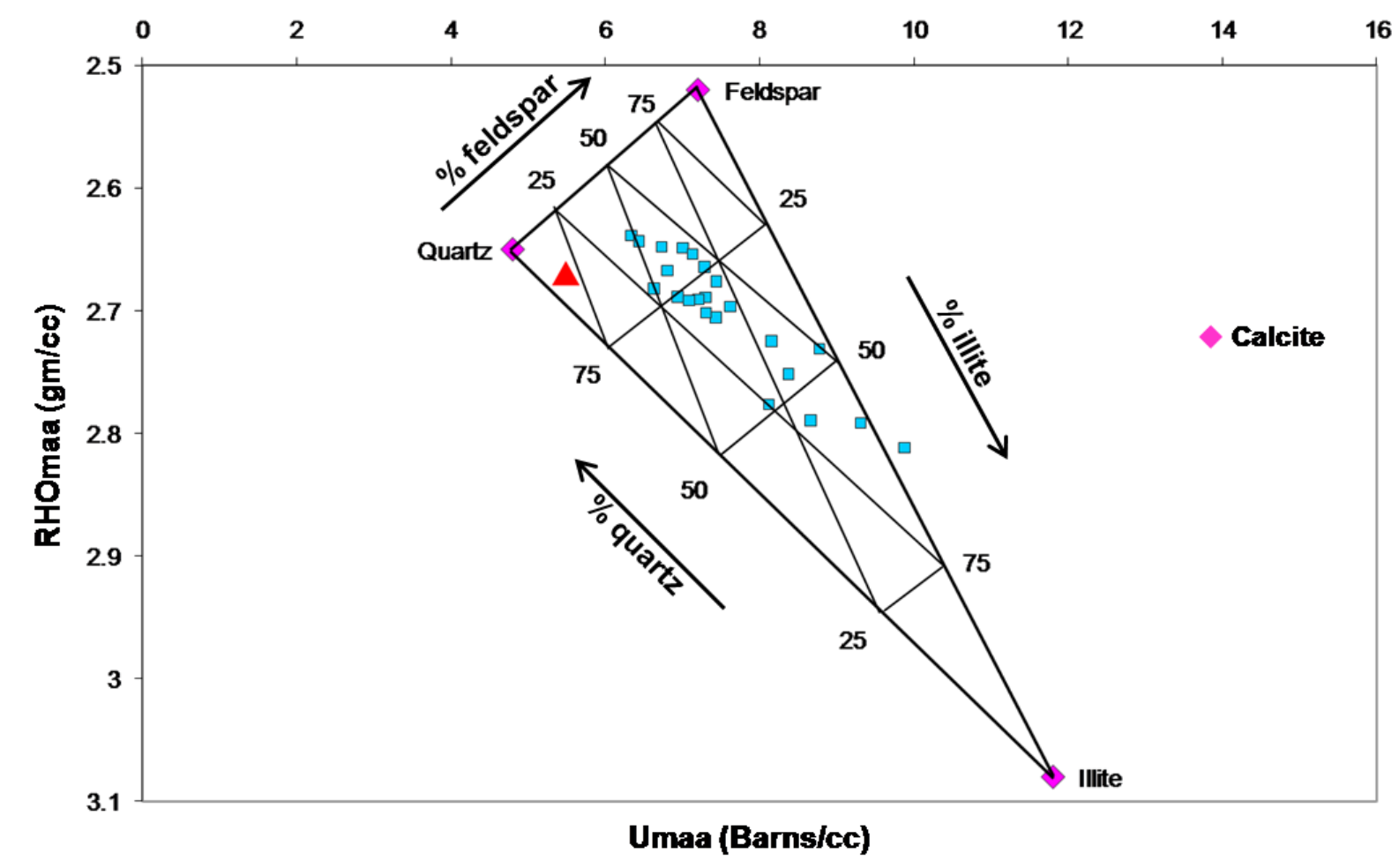

Figure 18. Upper B Fourth Sand RHOmaa-Umaa mineralogy crossplot for log: Petroleum Development Corporation Frey-808. Prominent lithic components consist of quartz, feldspar, and clay (illite). The Upper B Fourth Sand in contrast to the Upper A Fourth Sand (Figure 14) contains negligible calcite. The red triangle is lithology based on XRD mineralogy from a nearby well (Petroleum Development Corporation Williams560). The core data is from a cleaner Upper B Fourth sandstone, but confirms the absence of calcite. 


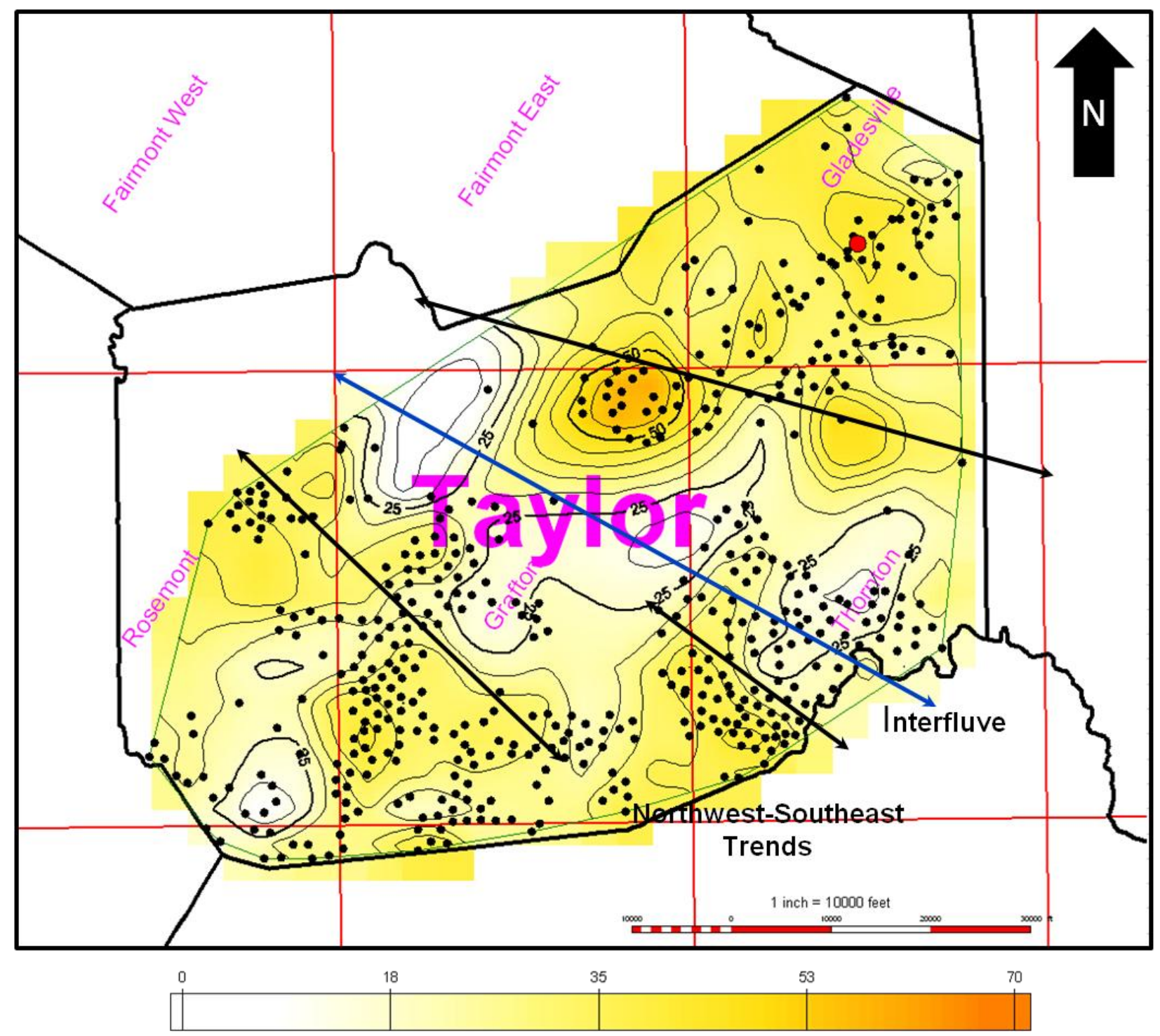

Map Legend

Well Location

Type Log-Core Plug

Figure 19. Upper B Fourth Isopach Map. Distribution is thick with an average gross sand of 35 feet $(11 \mathrm{~m})$ across the study area. The distribution consists of two thick areas oriented northwest-southeast separated by an area of thin sandstone. The thin area is interpreted as an interfluve between two channel complexes. Contour interval $(\mathrm{Cl})$ is 5 feet $(1.5 \mathrm{~m})$. 
overlying ravinement surface with the marine sandstone of the Upper A Fourth Sand sharply overlying the non-marine or estuarine Upper B Fourth Sand unit.

\section{Lower C Fourth Sand}

The Lower C Fourth Sand is a serrated, funnel-shaped sandbody (Figure 20). The sandbody has a coarsening upwards log signature with a gradational base and sharp upper surface. This sandbody has a low porosity reading ( $<2 \%$ density porosity) with a limited or no presence of hydrocarbons.

The Lower C Fourth Sand density-neutron and RHOmaa-Umaa crossplots indicate a calcite (limestone), clay (illite), and quartz lithology (Figures 21 and 22). Data points are distributed along a line with very low density porosity $(\sim 0 \%)$ and increasing neutron porosity indicating increasing amount of clay minerals. The Lower C Fourth Sand also contains a carbonate component.

The Lower C Fourth Sand isopach map illustrates a prominent northeastsouthwest strike-trending geometry with a possible lobate shoreline toward the northwest (Figure 23). Distribution is concentrated to the northeast, but relatively shallow with an average gross sand of 7 feet $(2 \mathrm{~m})$. The Lower C Fourth Sand thins toward and eventually is not present to the southwest. The sandbody The Lower $C$ is also interpreted to have been eroded by the Upper B Fourth fluvial-deltaic systems. AA' northeast to southwest cross-section illustrates the Lower C Fourth Sand unit thin across the study area (Figures 24 and 25).

Based on the core and log data, the Lower C Fourth Sand has been previously interpreted as a marine sandstone deposited along a muddy lobate shoreline along a shallow foreland-ramp basin to the northeast (Boswell and Jewell, 1988). Following 


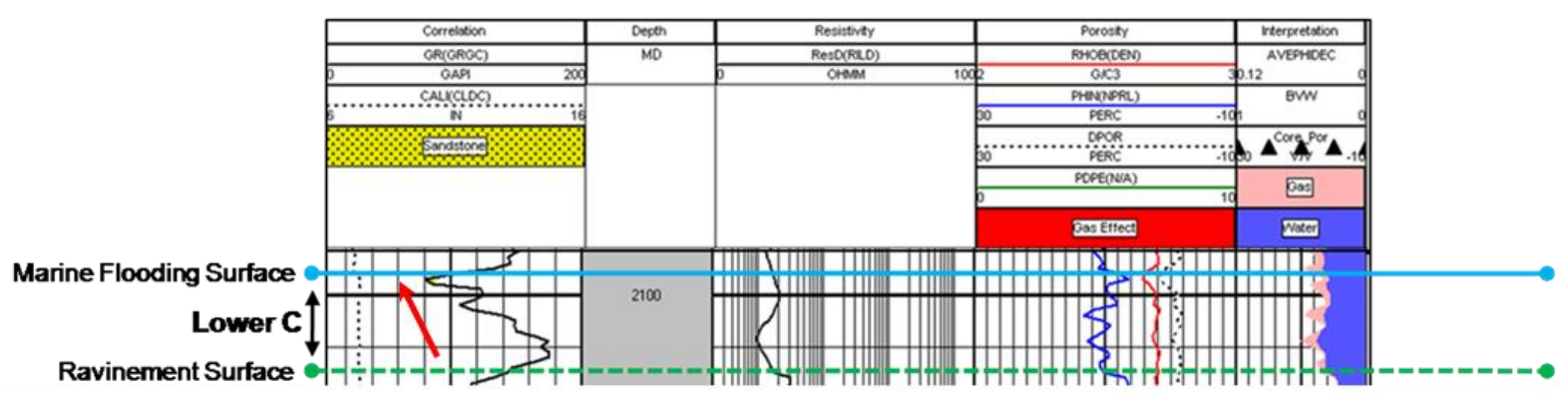

Figure 20. Lower C Fourth Sand Type Log: Petroleum Development Corporation Williams-560. The red arrow indicates that the Lower C sandbody has a serrated, funnel-shaped log signature with a coarsening (cleaning) upwards pattern (red arrow) and sharp upper surface. 
TAY-560 Lower C Fourth Sand 2095-2115FT

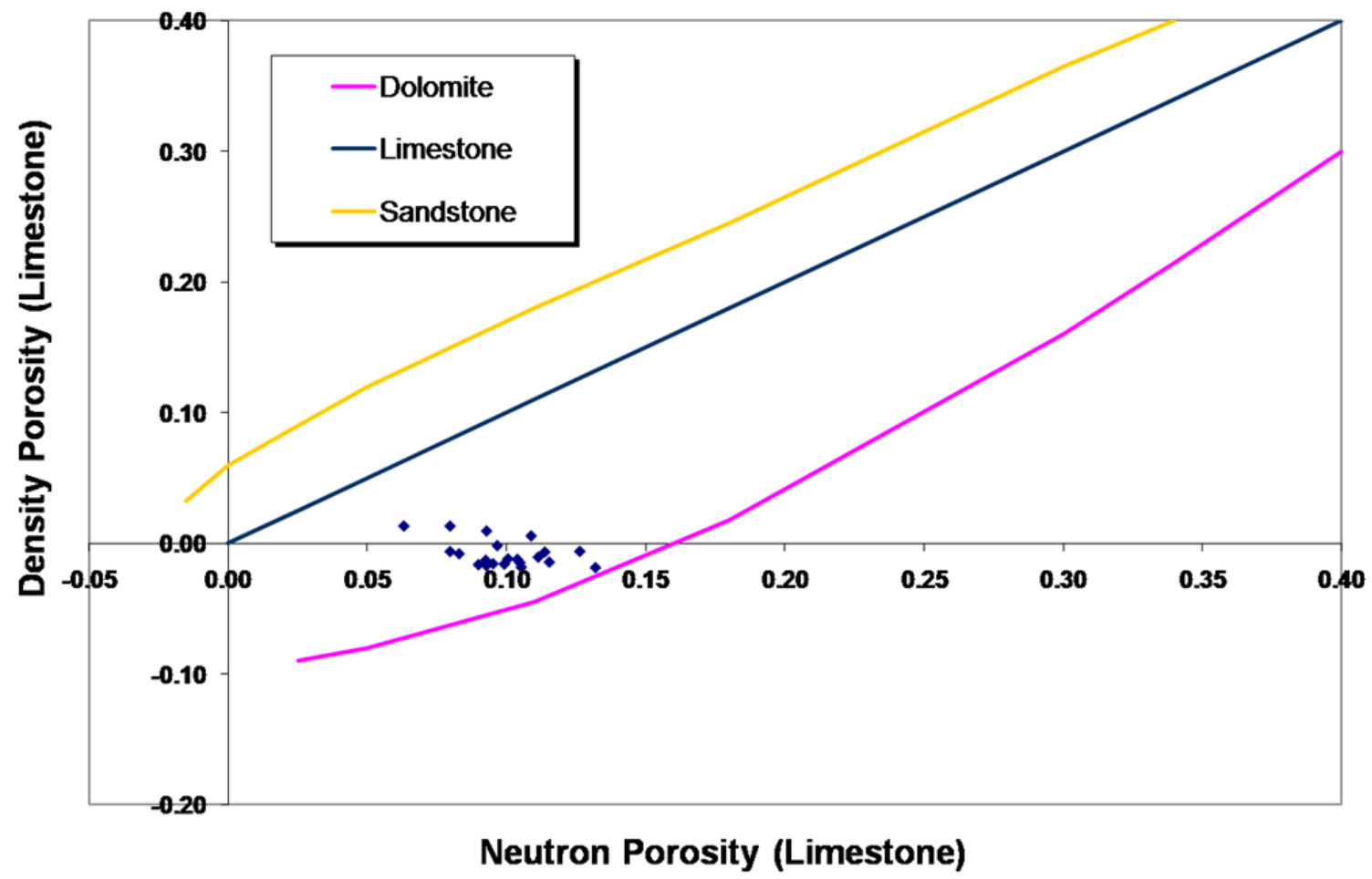

Figure 21. Lower C Fourth Sand density-neutron lithology crossplot for type log: Petroleum Development Corporation Williams-560. The plot indicates that the interval may contain significant carbonate (limestone) component. The horizontal trend along the zero percent density porosity, indicated by increased apparent neutron porosity is related to a shale-rich content. 
TAY-808 Lower C Fourth Sand 2530-2544FT

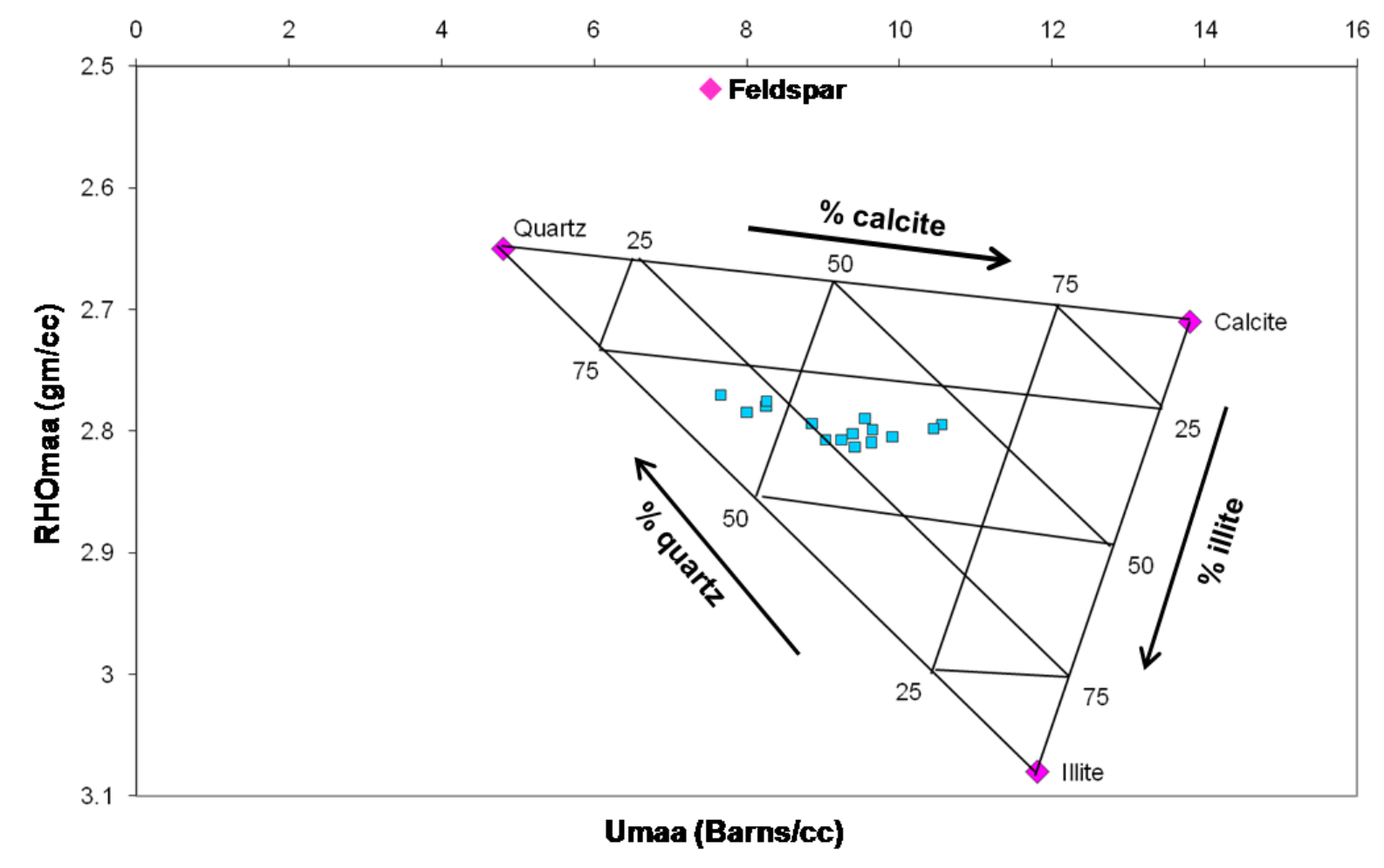

Figure 22. Lower C Fourth Sand RHOmaa-Umaa mineralogy crossplot for type log: Petroleum Development Corporation Frey-808. Prominent lithic components consist of calcite (limestone), clay (illite), and quartz. 


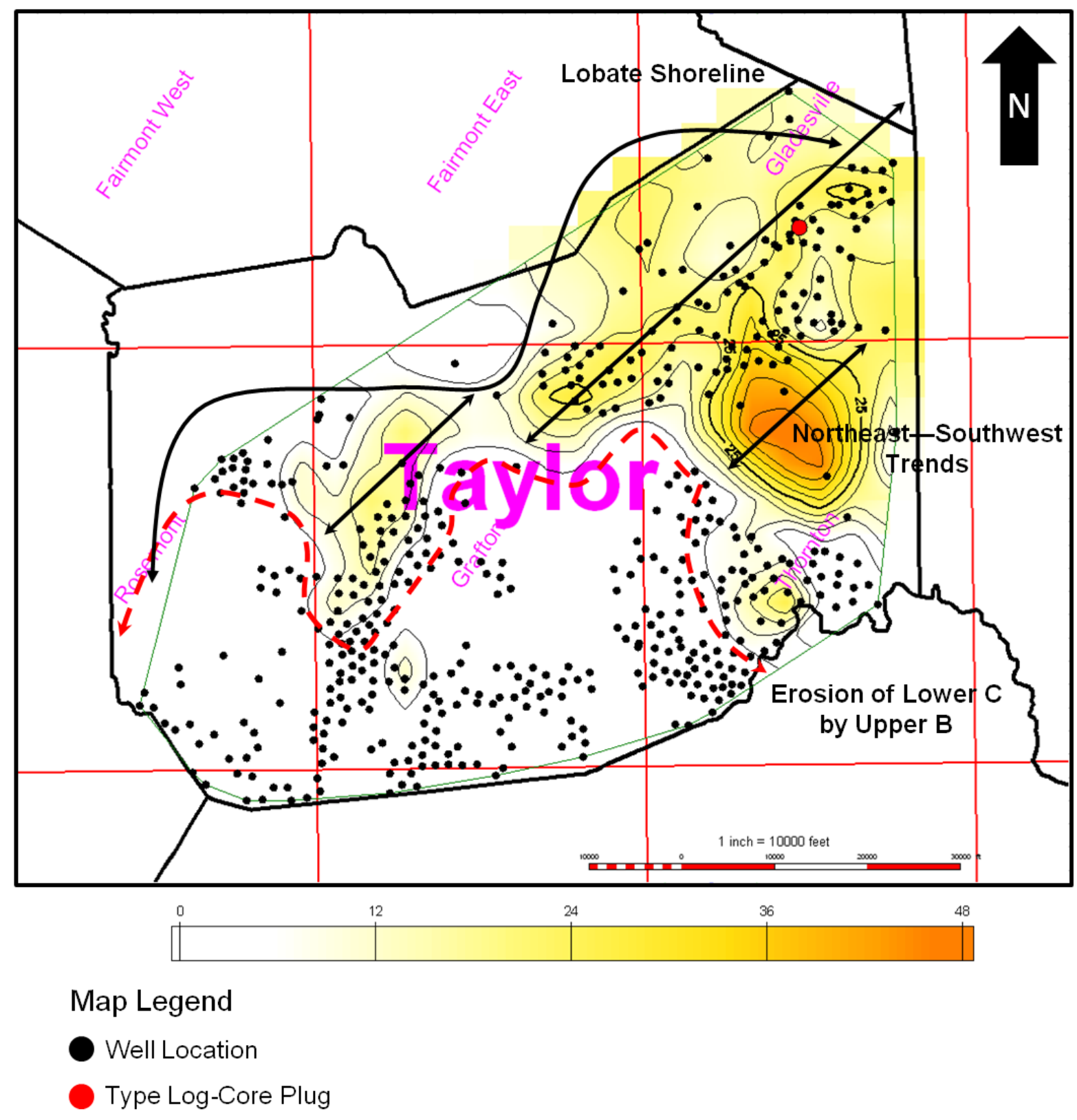

Figure 23. Lower C Fourth Sand Isopach Map. Distribution is concentrated in the northeast of the study area, but relatively thin with an average gross sand of 7 feet (2 $\mathrm{m})$. 


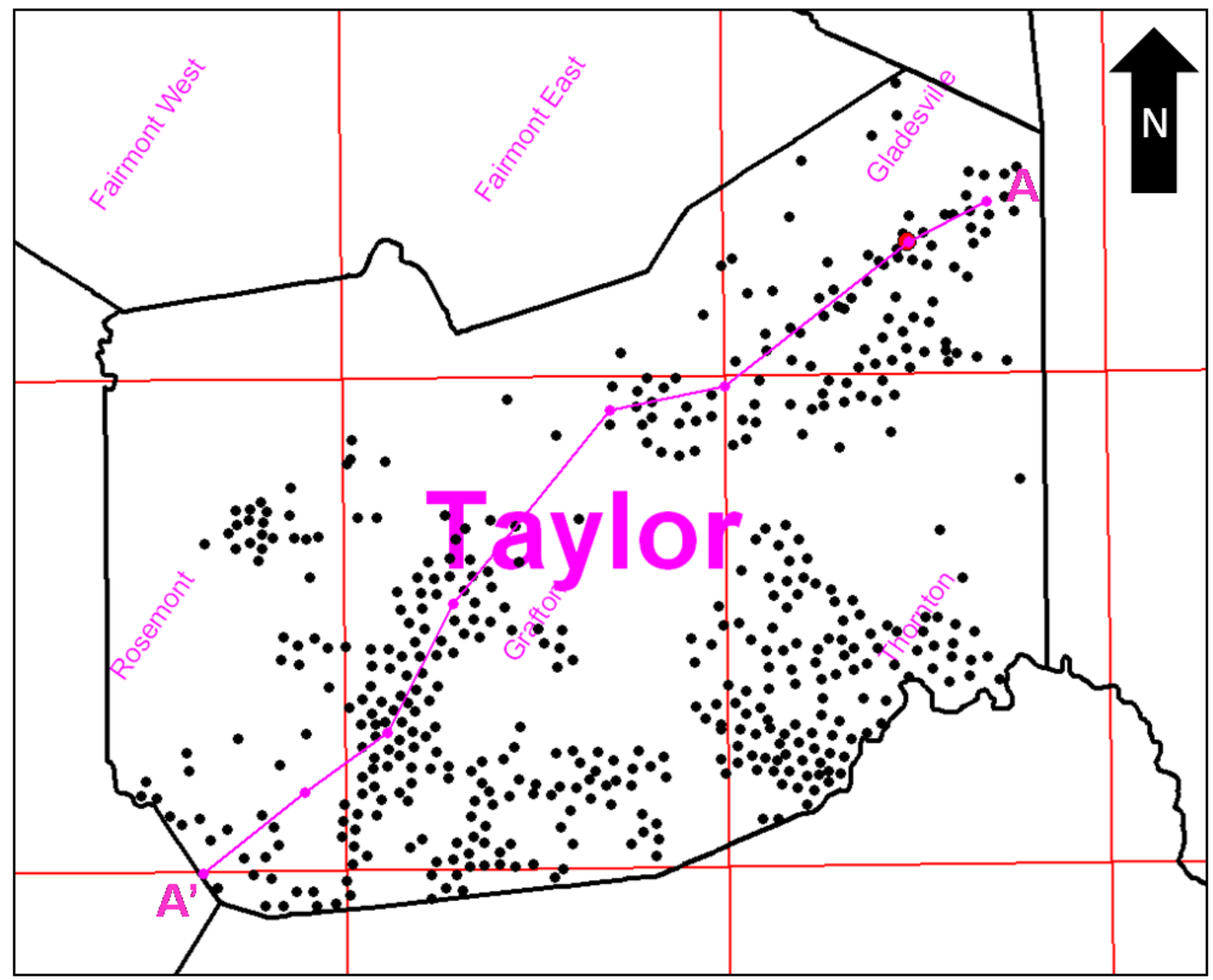

Map Legend

Well Location

Type Log-Core Plug

$A \longrightarrow A^{2}$ NE-SW Cross-Section Line

Figure 24. A-A' northeast to southwest stratigraphic cross-section line located across the study area. 

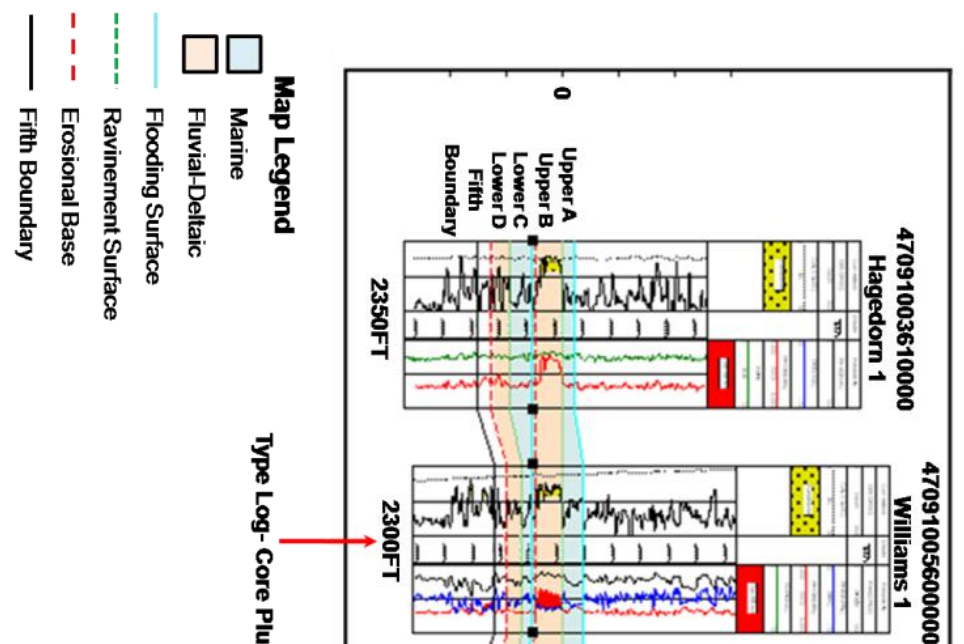

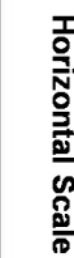

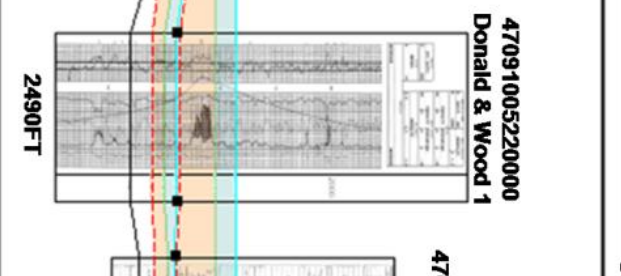

D
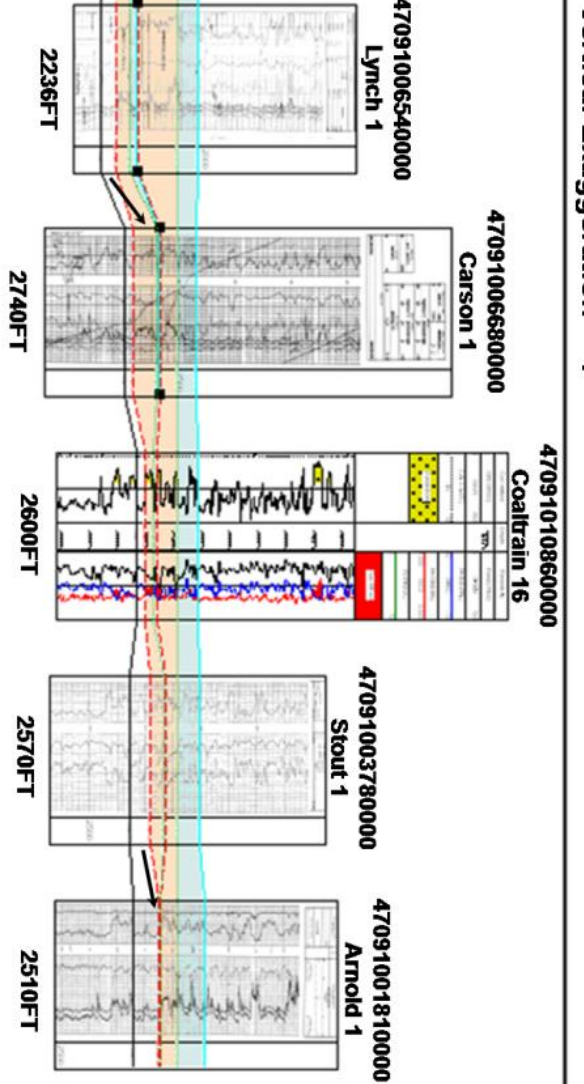

z

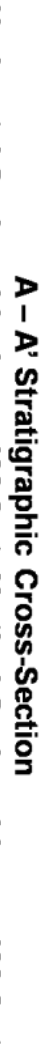


a previous result, the Lower C Fourth Sand in this study is interpreted as a marine sand unit similar to the Upper A Fourth Sand unit. The serrated, funnel-shaped log with a gradational base and sharp upper surface supports the interpretation of the Lower C Fourth Sand as prograding argillaceous marine sandstone (Wilson and Nanz, 1959). Density-neutron and RHOmaa-Umaa crossplots indicate that the unit contains significant calcite and clay mineral components. Abundant clay minerals are also supported by the relatively high gamma-ray readings and interbeds of sandstone and shale. The sharp contact of the sandstone with the overlying shale is interpreted as a flooding surface.

\section{Lower D Fourth Sand}

The Lower D Fourth Sand is a serrated, cylinder or blocky-shaped sandbody, similar to the Upper B Fourth Sand (Figure 26). The sandbody has a log signature with a low gamma-ray reading, similar to the Upper B Fourth Sand. Porosity crossplots of the Lower D Fourth Sand indicate the presence of hydrocarbons under the gas effect. Data points located above the sandstone lithology line in the density-neutron crossplot are in agreement with the presence of hydrocarbons (Figure 27). The density-neutron and RHOmaa-Umaa crossplots indicate quartz (sandstone), feldspar, and clay (illite) dominated lithology with an absence of calcite (Figure 28). The location of the rotary sidewall core (red triangle) in the RHOmaa-Umma crossplot is in agreement with the mineralogy.

The Lower D Fourth Sand isopach map illustrates a northwest-southeast diptrending geometry (Figure 29). Average gross sand is 16 feet $(5 \mathrm{~m})$ across the study area. However, the Lower D Fourth Sand thins toward the southwest and is interpreted 


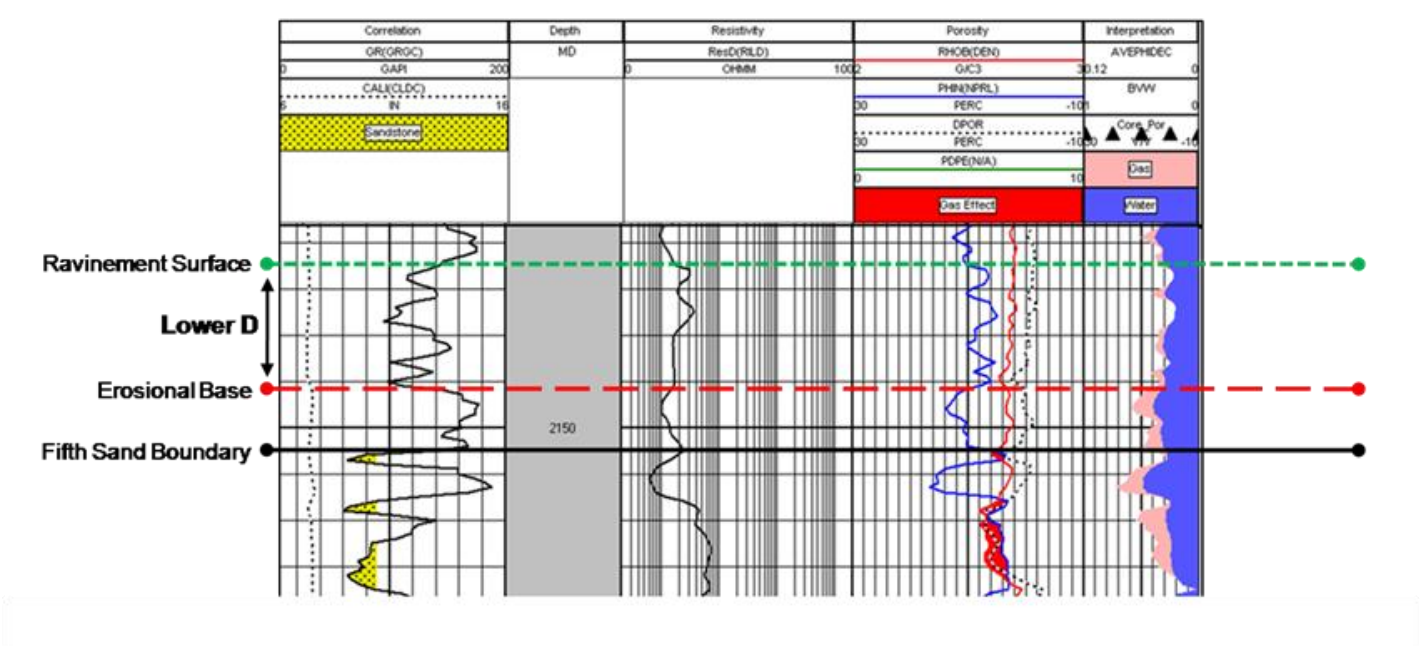

Figure 26. Lower D Fourth Sand Type Log: Petroleum Development Corporation Williams-560. The Lower D sandbody has a blocky-serrated log signature with sharp lower and upper surfaces. 
TAY-808 Lower D Fourth Sand 2544-21577FT

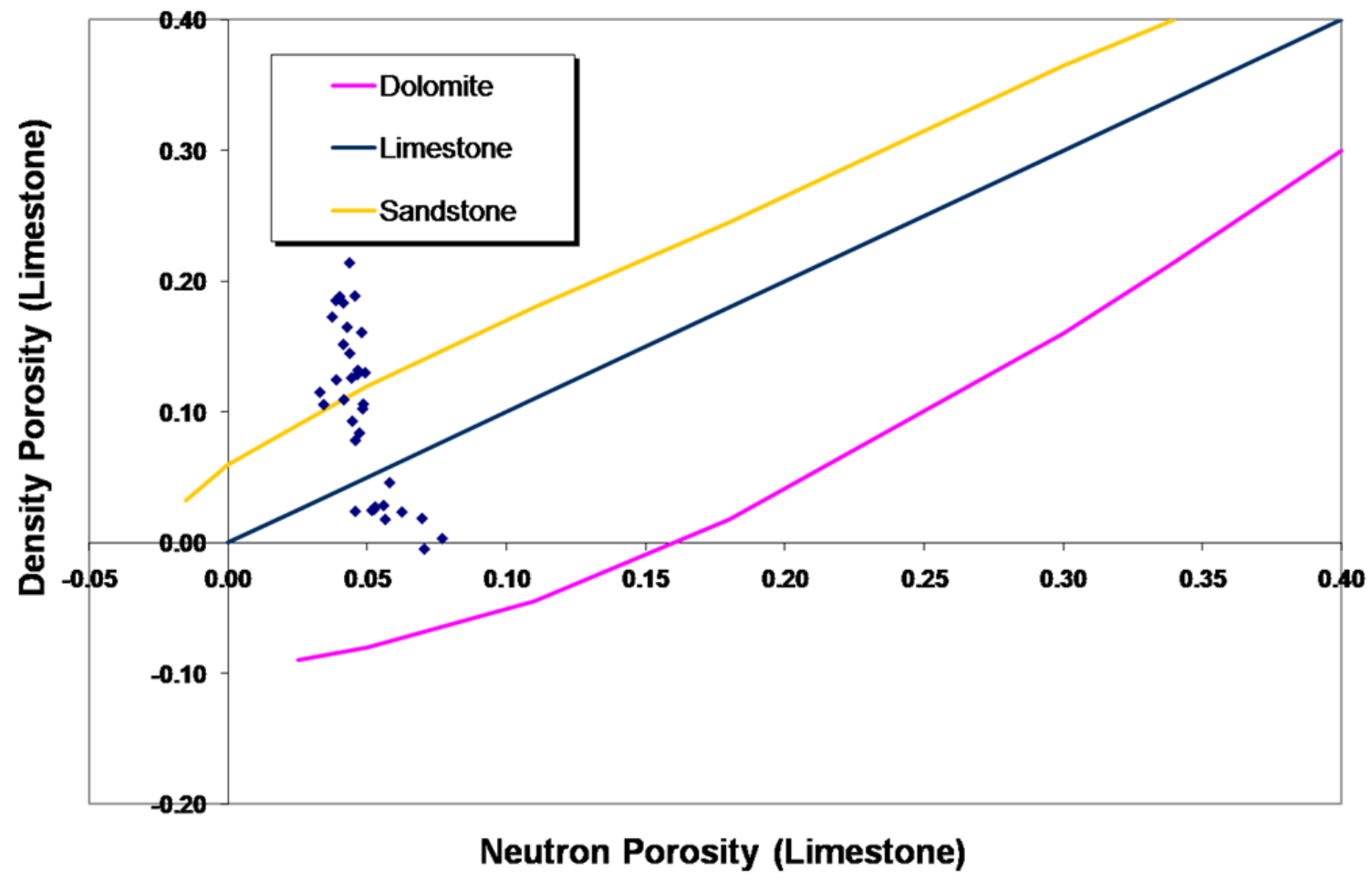

Figure 27. Lower D Fourth Sand density-neutron lithology crossplot for log: Petroleum Development Corporation Frey-808. Data points located above the sandstone lithology line indicate the presence of gas. As density porosity decreases to zero, the neutron porosity indicates the presence of clay. 
TAY-808 Lower D Fourth Sand 2544-2577FT

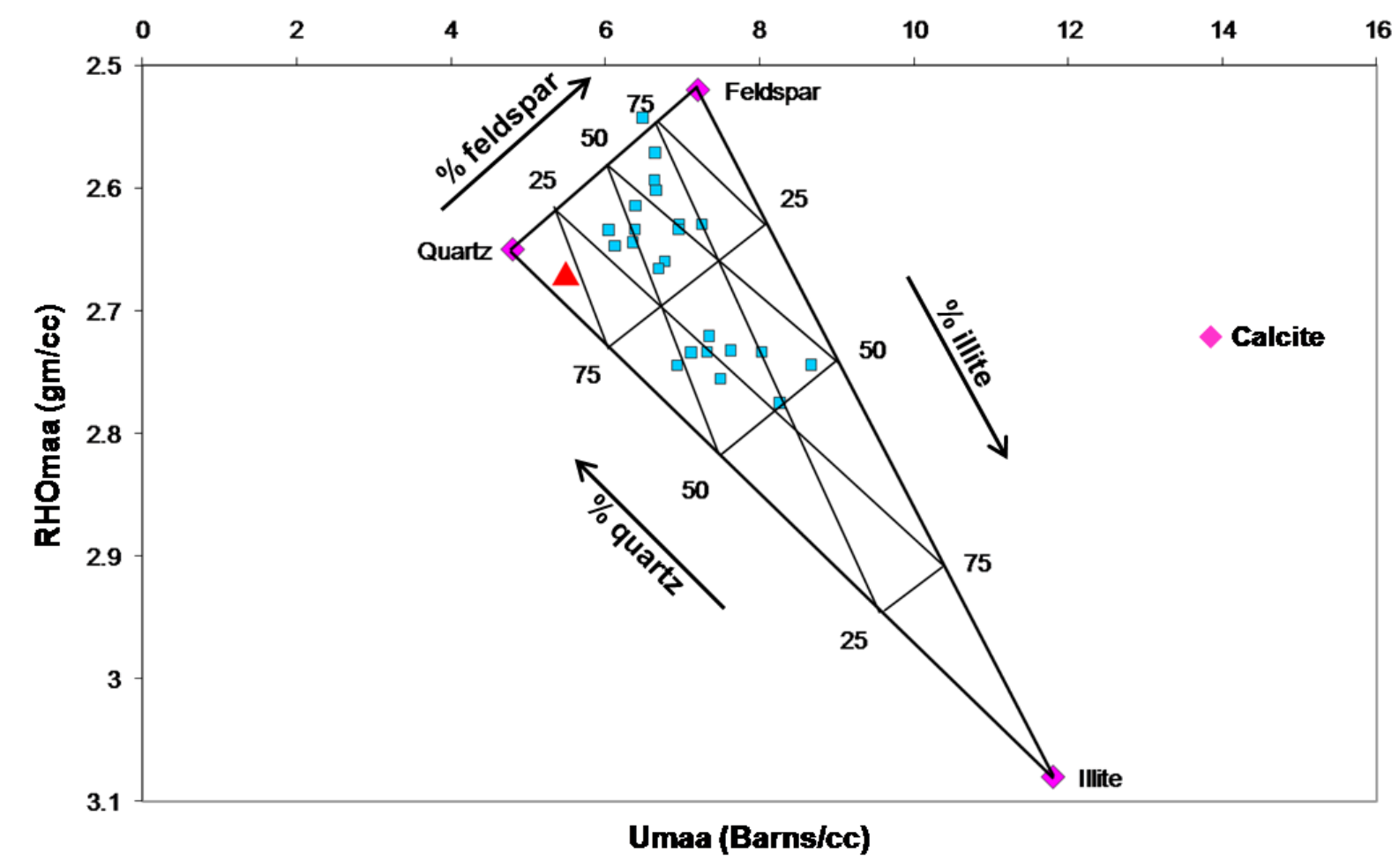

Figure 28. Lower D Fourth Sand RHOmaa-Umaa mineralogy crossplot for log: Petroleum Development Corporation Frey-808. Prominent lithic components consist of quartz, feldspar, and clay (illite). The red triangle is the location of the one rotary sidewall core: Petroleum Development Corporation Williams-560 based on XRD, mineralogy, and relative clay abundances data. 


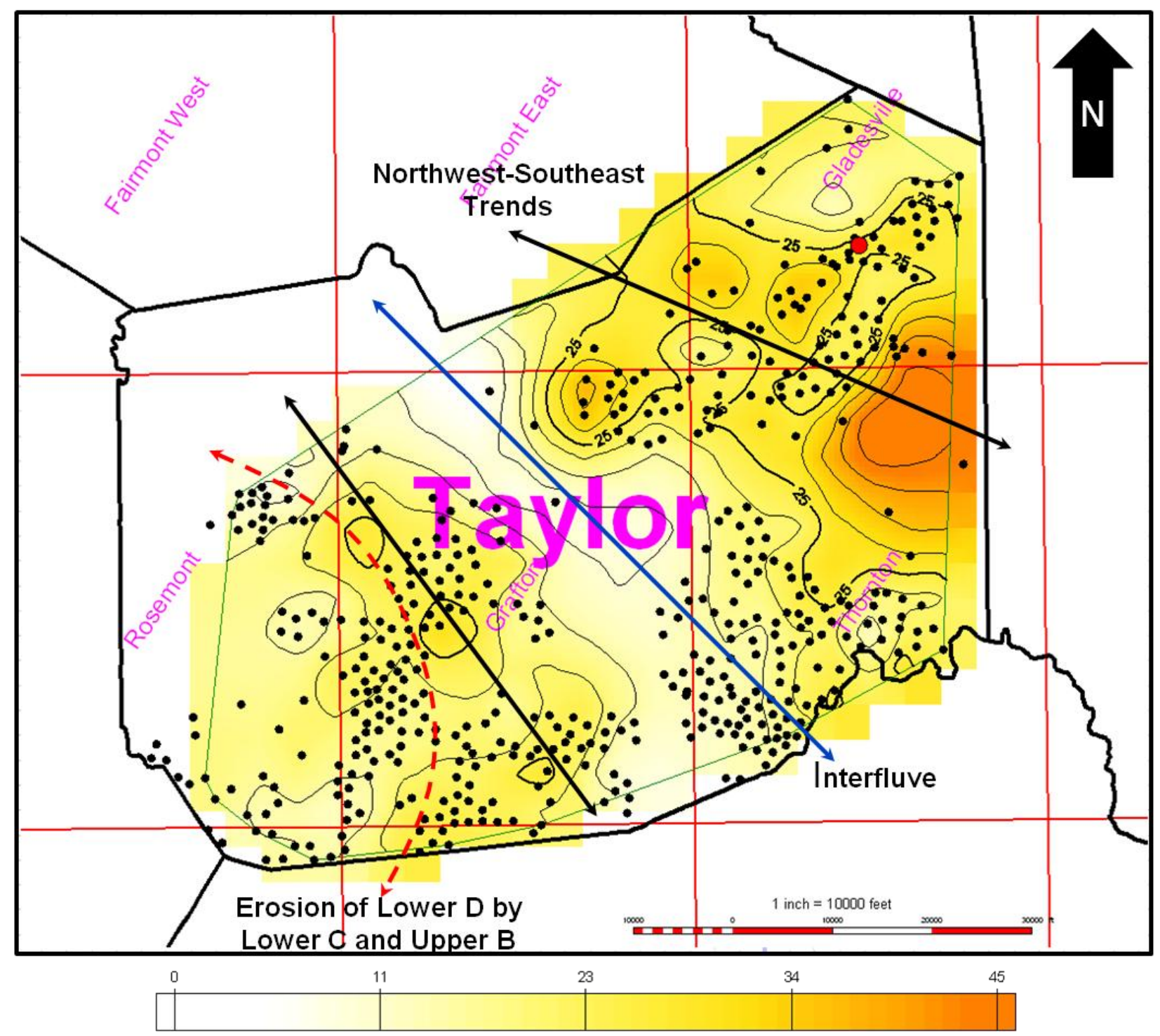

Map Legend

Well Location

Type Log-Core Plug

Figure 29. Lower D Fourth Isopach Map. Distribution is relatively thick with an average gross sand of 16 feet $(5 \mathrm{~m})$ and is in northwest-southeast geometry. Contour interval $(\mathrm{Cl})$ is 5 feet $(1.5 \mathrm{~m})$. 
to have been eroded by the overlying marine Lower Fourth Sand C and non-marine Upper B Fourth sandstone units. A-A' northeast to southwest stratigraphic crosssection also illustrates the Lower D Fourth Sand unit thin across the study area (Figures 24 and 25).

The Lower D Fourth Sand has been interpreted as multiple fluvial-deltaic systems that flow to the northwest and were deposited along a muddy lobate coastline (Boswell and Jewell, 1988). The Lower D Fourth Sand is interpreted as non-marine or estuarine sandstone similar to the Upper B Fourth Sand unit. The serrated, blockyshaped log signature with a sharp lower and upper surfaces support the fluvial-deltaic interpretation and the sharp boundaries of the Lower D sand are interpreted as an erosional base and overlying ravinement surface (Wilson and Nanz, 1959). Data points located above the sandstone lithology line in the density-neutron crossplot indicate the presence of hydrocarbons. 


\section{SAMPLE DATA}

Available sample data is limited to one rotary sidewall core (2080 feet depth) from the Upper B Fourth sandstone unit. Accompanying XRD, mineralogy, and relative clay abundances data indicate that the dominant minerals are quartz, plagioclase, and clay (illite) (Figure 30). The single XRD mineralogy is plotted on the RHOmaa-Umaa plot for the Upper B Fourth Sand (Figure 18). A thin section was made from the rotary sidewall core. The thin section was described and dominant minerals were identified to further interpret the Upper B Fourth Sand and to calibrate the log crossplots.

\section{Thin Section Description and Interpretation}

The sidewall core sample is a moderate to poorly-sorted, sub-angular to angular, medium-grained argillaceous sandstone (Figure 31). Dominant grains include quartz, plagioclase feldspar, and clay minerals. Other minor grains identified in thin section consist of irregular calcite cement grains and chert rock fragments.

Quartz was the most prominent mineral identified in thin section that ranged in a variety of sizes from medium to coarse-grained sand, and sub-angular to angular grain shapes (Figure 32). Fine to medium-grained sand-size plagioclase feldspar crystals were found in limited quantities (Figure 33). Minerals identified in thin section include muscovite, chlorite, and unidentified reddish-brown grains. Elongate-shaped muscovite fragments were found squeezed between other quartz and plagioclase feldspar grains (Figure 34). Small, silt-sized medium to olive-green chlorite crystals were identified, but found in negligible quantities (Figure 35). The reddish-brown unidentified clay grains are found in large quantities between grains and appear to coat grains (Figure 36). 


\begin{tabular}{|l|c|c|}
\hline \multicolumn{3}{|c|}{ Bulk Mineralogy } \\
\hline \multicolumn{1}{|c|}{ MINERALS } & XRD & MINERALOGY \\
\hline Quartz & 74 & 76 \\
\hline Plagioclase & 9 & 4 \\
\hline K-feldspar & 0 & 3 \\
\hline Calcite & 0 & 0 \\
\hline Dolomite & 1 & 0 \\
\hline Total Clay Minerals & 16 & 17 \\
\hline
\end{tabular}

\begin{tabular}{|c|c|c|}
\hline \multicolumn{3}{|c|}{ Relative Clay Abundances } \\
\hline CLAYS & XRD & MINERALOGY \\
\hline Kaolinite & 0 & Absent \\
\hline Chlorite & 2 & Absent \\
\hline Illite & 79 & Present \\
\hline Smectite & $\mathrm{N} / \mathrm{A}$ & Present \\
\hline Mixed-Layer Illite/Smectite & 19 & $\mathrm{~N} / \mathrm{A}$ \\
\hline
\end{tabular}

Figure 30 . One rotary sidewall core $\mathrm{XRD}$, mineralogy, and relative clay abundances data for Petroleum Development Corporation Williams-560 at a sample depth of 2080 feet. Quartz, plagioclase, and illite highlighted in yellow were used as mineral endpoints to calibrate RHOmaa-Umaa crossplots (Figure 18). 


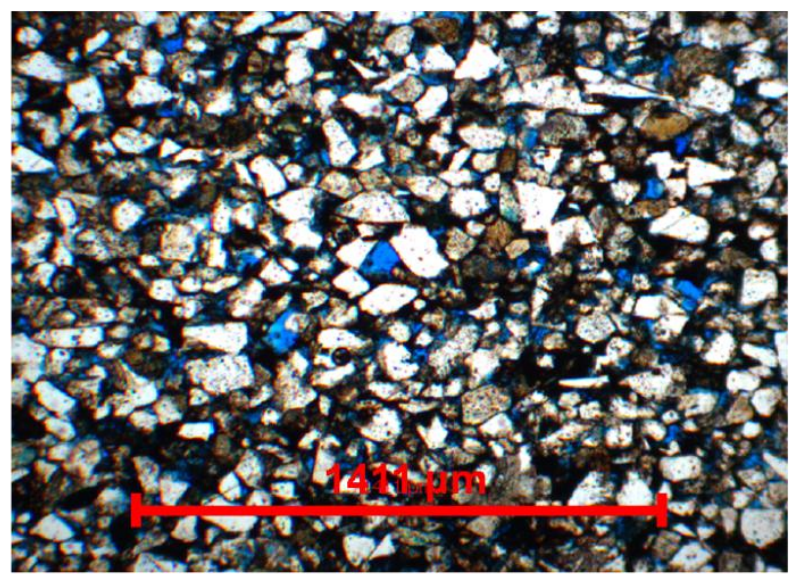

40X, PPL

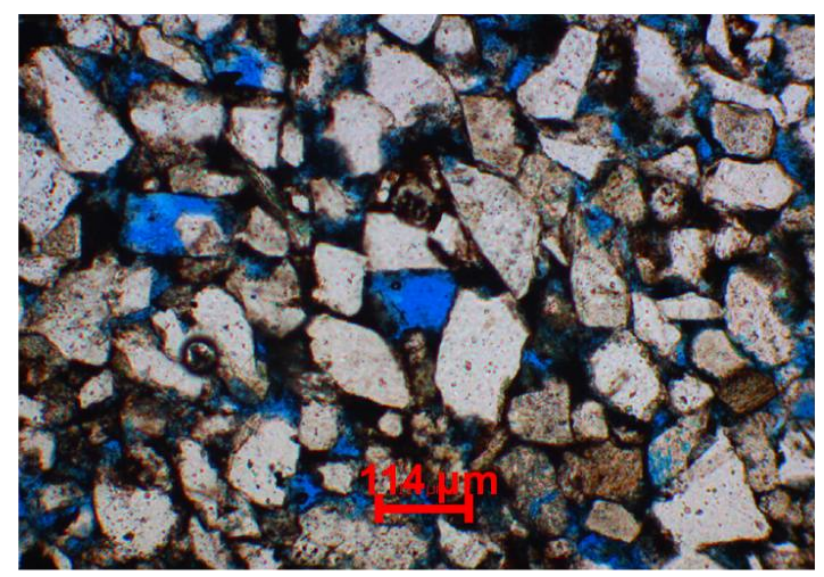

$100 X, X P L$

Figure 31. Thin section of the one rotary sidewall core and blue epoxy represents open pore space (intergranular porosity and dissolution porosity). 


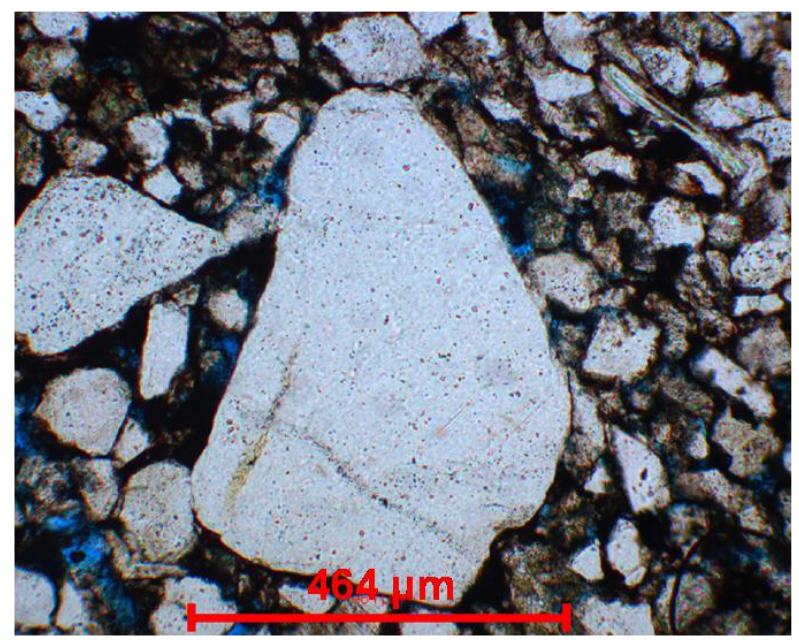

100X, PPL

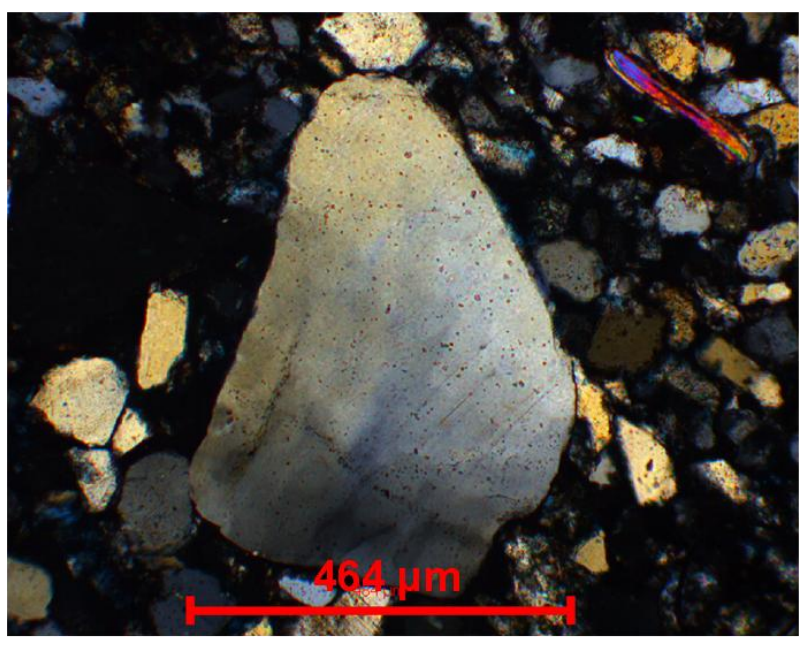

$100 \mathrm{X}, \mathrm{XPL}$

Figure 32. Thin section of a large quartz grain with undulatory extinction to the right. An elongate muscovite grain is present in the upper left corner. 


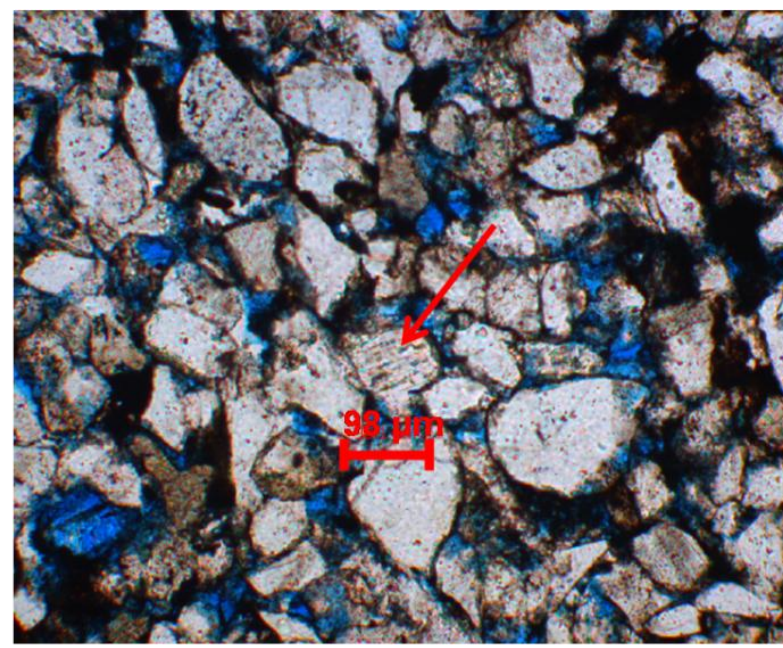

$100 X, P P L$

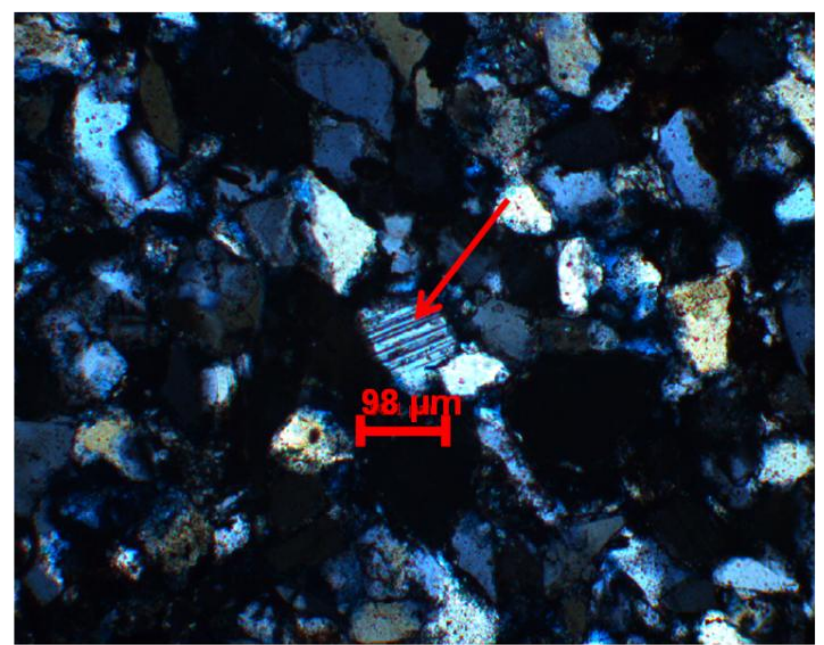

$100 \mathrm{X}, \mathrm{XPL}$

Figure 33. Thin section of plagioclase feldspar with lamellar (albite) twinning to the right. 


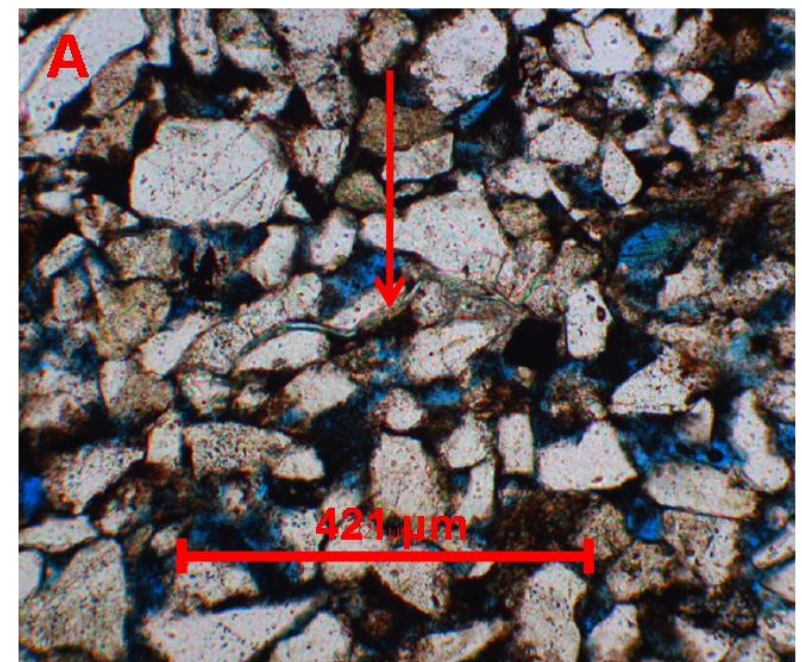

100X, PPL

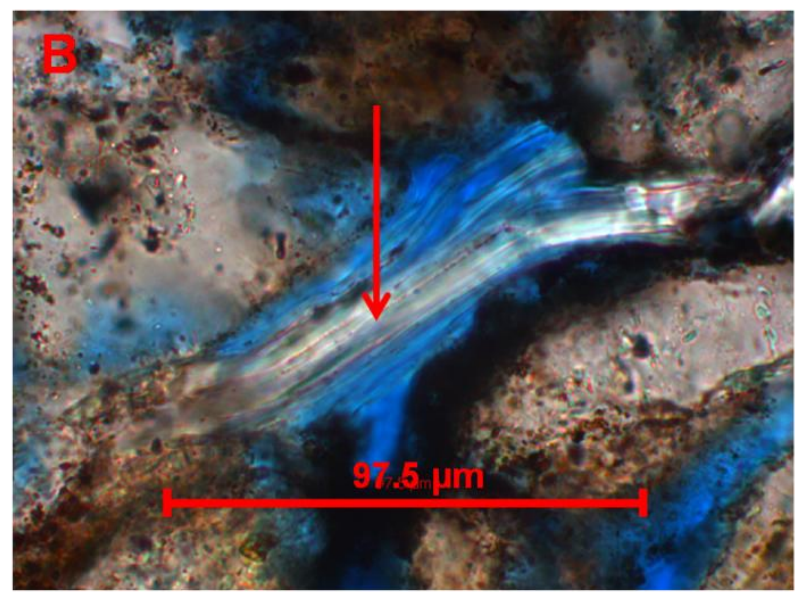

$630 X, P P L$

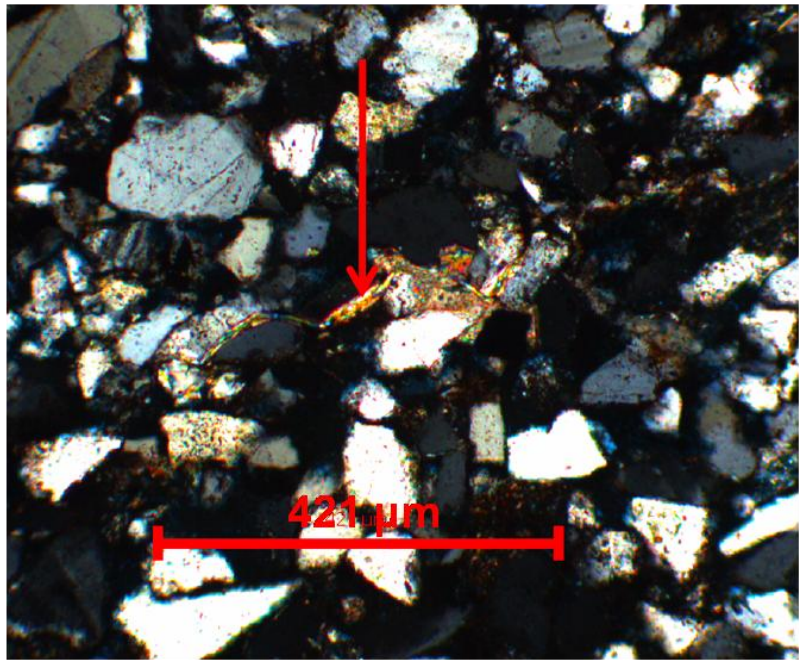

$100 X, X P L$

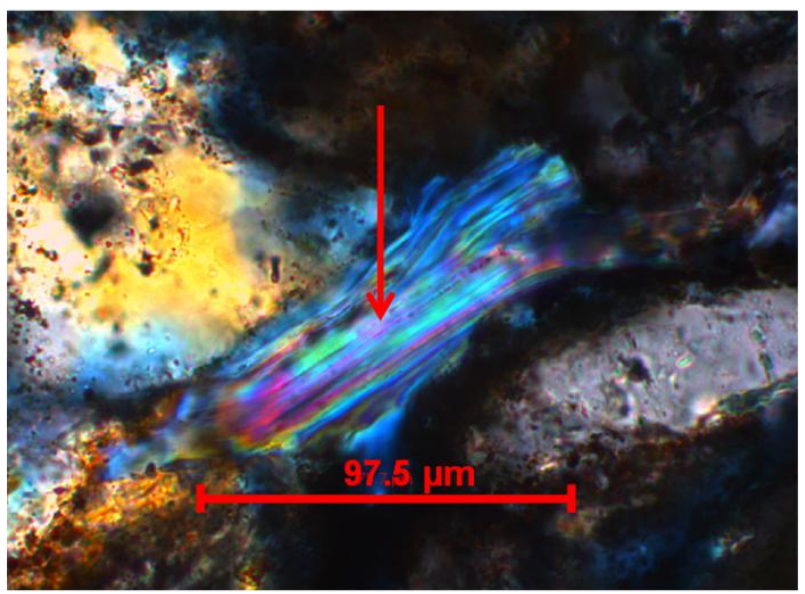

$630 X, X P L$

Figure 34. Pictures A and B: Thin section of a squeezed muscovite crystal between quartz grains. 


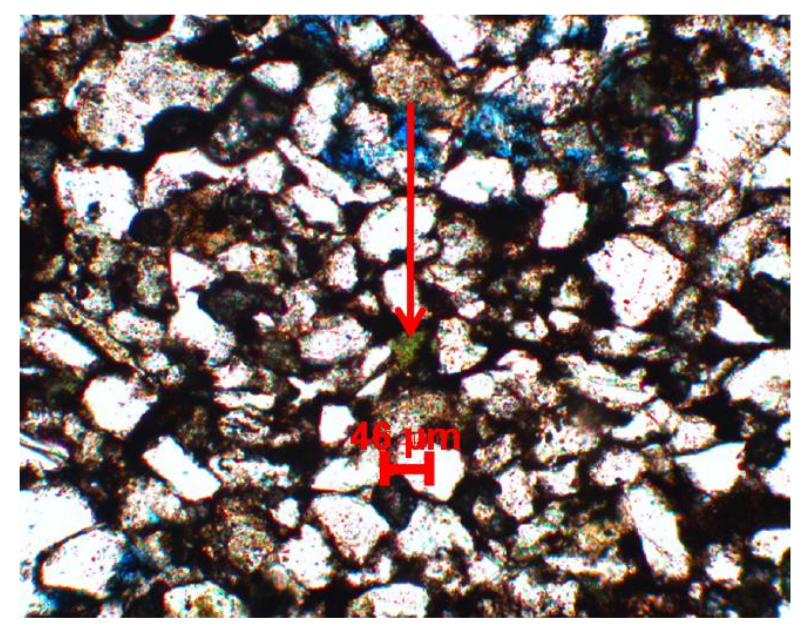

$630 X, P P L$

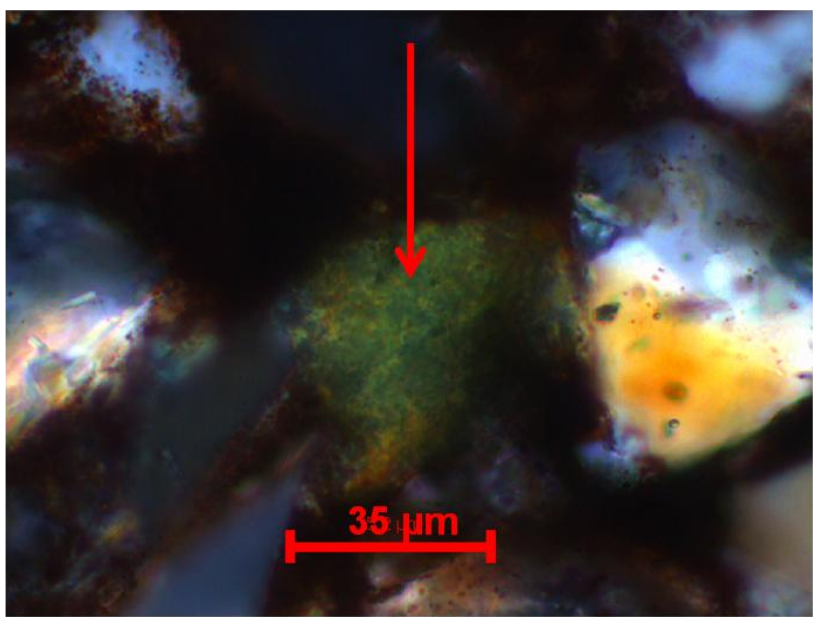

$630 X, X P L$

Figure 35. Thin section of a chlorite mineral with medium green to olive green colors (anomalous birefringence). 


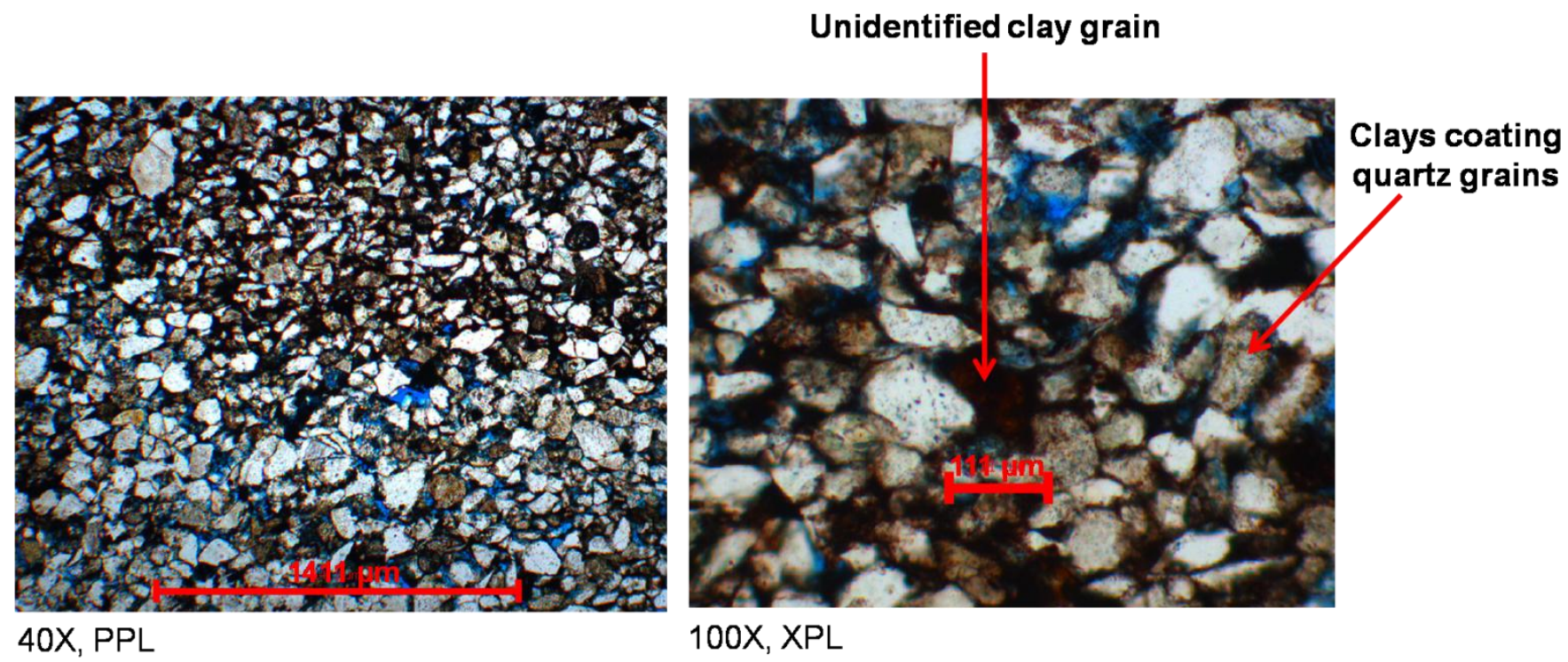

Figure 36. Thin section of reddish-brown, partially opaque, angular clay fragments between quartz grains and clay material coating quartz grains. 
Minimal quantities of large, irregular-shaped calcite cement areas between other grains were identified in thin section (Figure 37). Negligible chert rock fragments were also found in thin section (Figure 38). The XRD and thin section analysis indicate that the log crossplots provide an acceptable lithologic solution.

Based on the grain size, degree of roundness, sorting of grains, and composition, integrated with the log pattern the Upper B Fourth Sand is interpreted as a fluvial-deltaic argillaceous sandstone. Fluvial-deltaic systems carry large volumes of sediment that range in a variety of grain sizes from gravel to clay, and deposit sediments into marine environments by way of distributary channels (Scholle and Spearing, 1998).

Intergranular porosity and dissolution porosity is interpreted from the blue epoxy staining of the thin section (Figure 31). The blue epoxy represents open pore spaces; however, these pores are also blocked by other grains. Prominent pore-filling materials identified in thin section include elongate muscovite grains, unidentified reddish-brown clay minerals, and minimal large, irregular calcite cement grains.

Large quantities of clay minerals identified in thin section were found filling pore spaces between quartz grains and coating quartz grains. When clays fill pore spaces and coat grains, the irreducible water saturation of a formation increases due to clay bound water, significantly lowering resistivity values (Worthington, 2000 and Boyd et al., 1995). Other probable causes of low-resistivity pay include small grain size. Small grains have an increased surface area and can hold more irreducible water by capillary forces, causing low-resistivity values over a formation. One of the most common depositional environments for low-resistivity sandstone units are lower delta front (toe) 


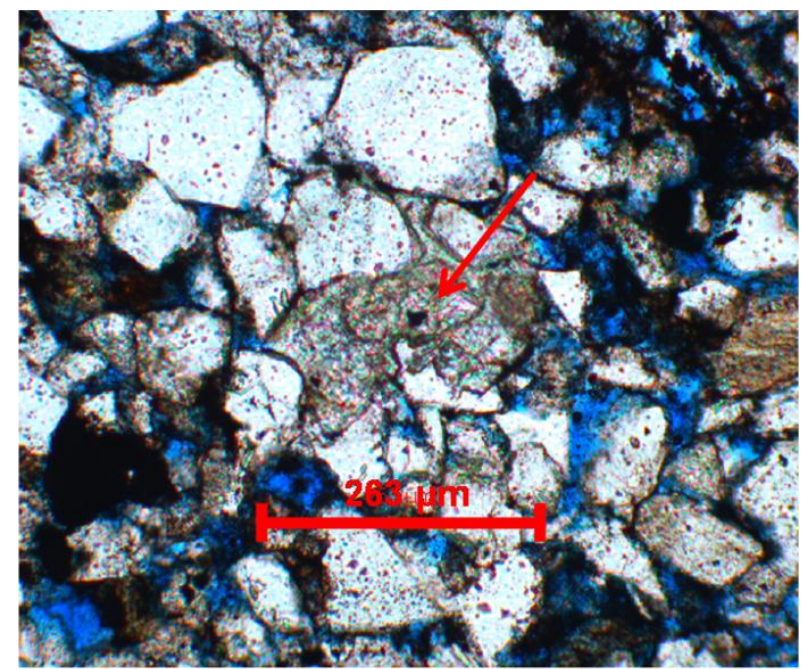

100X, PPL

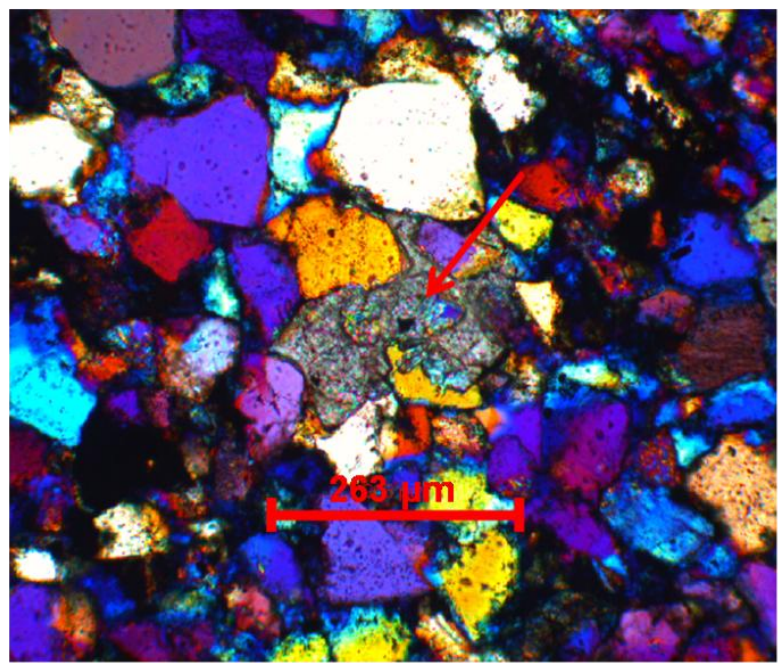

100X, XPL, Full-Wave Plate

Figure 37. Thin section of a large, irregular calcite cement grain between quartz grains. 


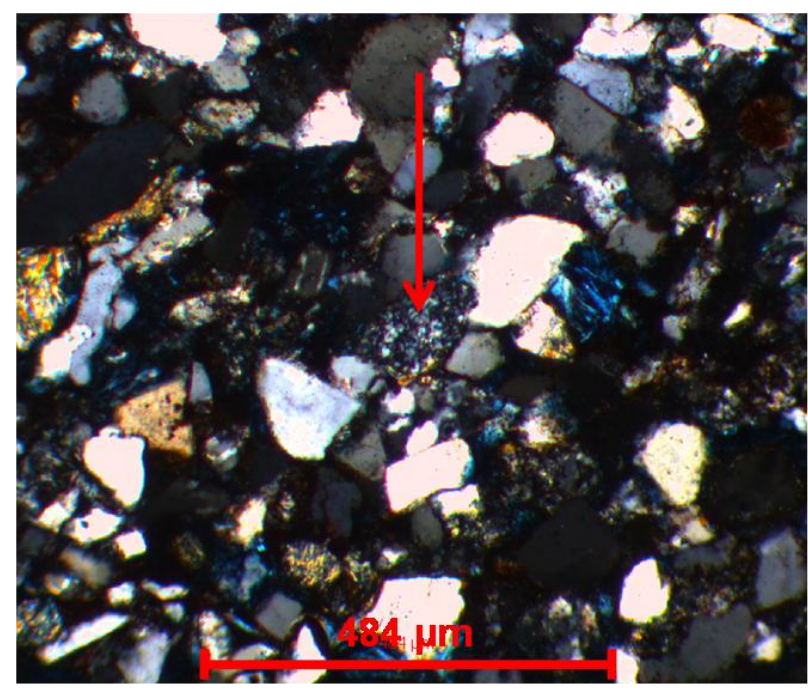

$100 \mathrm{X}, \mathrm{XPL}$

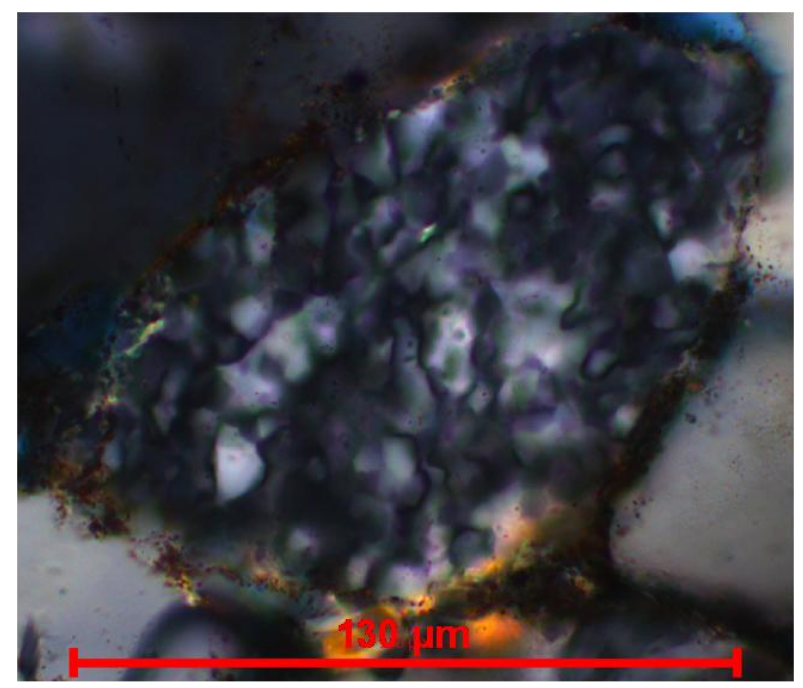

$630 X, X P L$

Figure 38. Thin section of a rounded chert rock fragment. 
deposits and laminated silt-shale-sand intervals in upper distributary channels (Boyd et al., 1995). The relatively high water saturation ( 50\%), computed for the Fourth Sand (Figure 11), but limited observed water production can be explained by the abundant clay observed in thin section and in electric logs. 


\section{RESERVOIR CHARACTERISTICS AND PRODUCTION DATA}

Reservoir characteristics and available production data were described and interpreted for each Upper Devonian Fourth sandstone unit. Based on the position of known producing intervals a gamma-ray cutoff of $90 \mathrm{API}$ units was selected to generate net sand isopach maps. In addition, the degree of cross-over between density porosity and neutron porosity maps, lithology interpretations, and inferred depositional environments were used to describe and interpret different Fourth Sand reservoir characteristics. Available co-mingled production data was used to construct hydrocarbon bubble maps in order to understand which Upper Devonian Fourth sandstone units are most productive within the study area.

\section{Upper A Fourth Sand}

The marine Upper A Fourth Sand net sand distribution is concentrated to the southwest with an average of 7 feet $(2 \mathrm{~m})$ (Figure 39). The sandbody has a very low porosity with a limited to nonexistent density-neutron cross-over in log view (lack of gas effect). The density-neutron porosity cross-over could not be mapped. Lithology crossplots describe the Upper A Fourth Sand composition containing primarily calcite (limestone), clays (illite), and quartz minerals (Figures 13 and 14).

The Upper A Fourth Sand low porosity and negligible hydrocarbons may be the result of calcite cement between intergranular sand grains. The degree of cross-over map is not shown because cross-over between density porosity and neutron porosity curves were negligible. No production data was found associated with the Upper A Fourth Sand unit. The marine Upper A Fourth Sand is interpreted as a non-reservoir unit in the study area. 

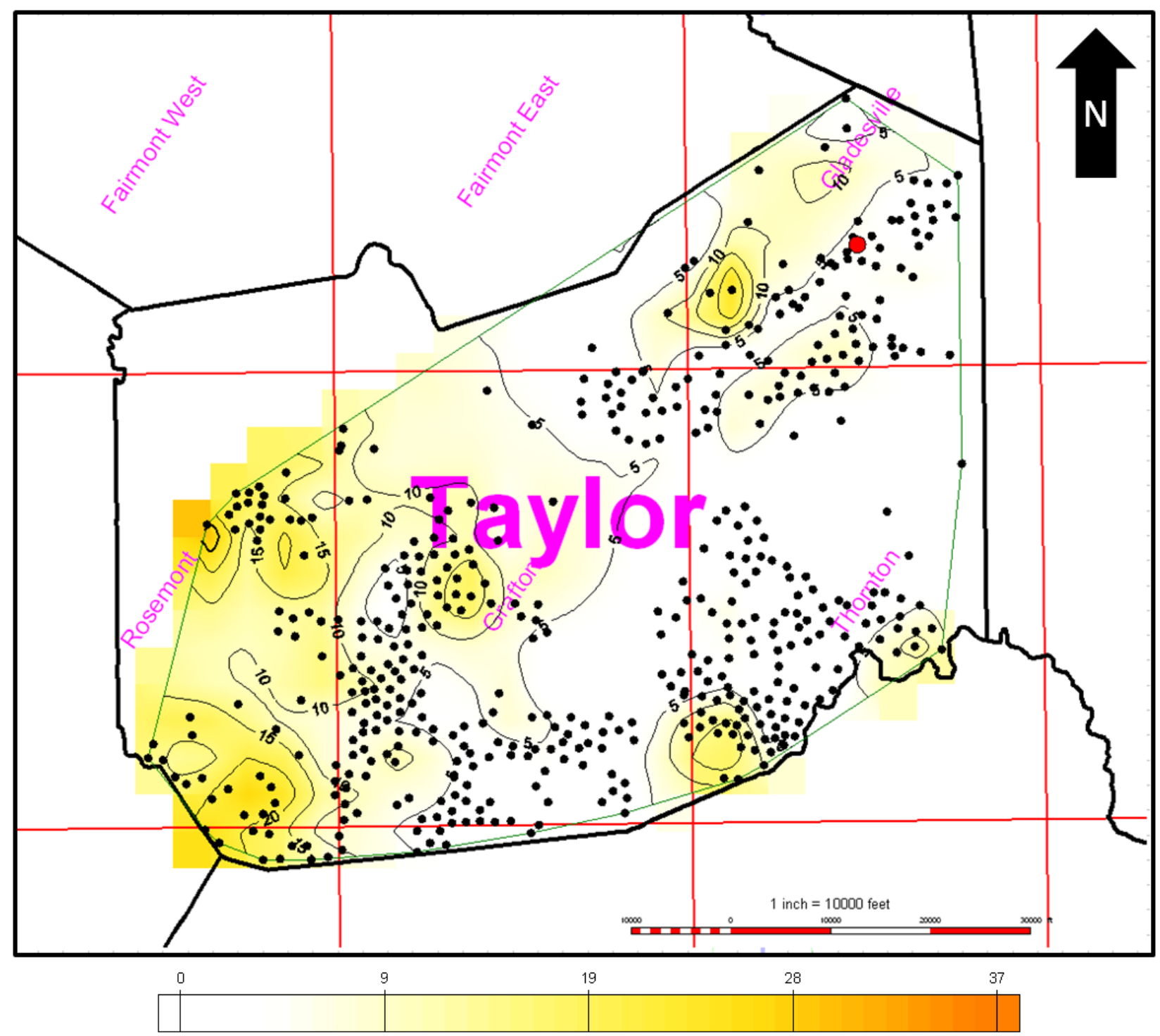

Map Legend

Well Location

Type Log-Core Plug

Figure 39. Upper A Fourth Net Sand Map with a gamma-ray cutoff of $90 \mathrm{API}$. Sand distribution is concentrated to the southwest with an average thickness of 7 feet $(2 \mathrm{~m})$. Contour interval $(\mathrm{Cl})$ is 5 feet $(1.5 \mathrm{~m})$. 


\section{Upper B Fourth Sand}

The fluvial-deltaic Upper B Fourth Sand net sand distribution is relatively widespread throughout the study area, especially toward the northeast, with an average net sand thickness of 17 feet $(5 \mathrm{~m})$ (Figure 40$)$. This sandbody has a high degree of density-neutron cross-over with an average of 8 feet $(2.5 \mathrm{~m})$, is interpreted as the gas effect (Figure 41) (Asquith and Krygowski, 2004). Lithology crossplots and available sample data indicate that the Upper B Fourth Sand composition consists of quartz (sandstone), plagioclase feldspar, and clay minerals (Figures 17 and 18). Large quantities of clay minerals observed in thin section, fill pore spaces and coat framework sandstone grains. Calcite cement in thin section is minimal.

Under fluvial-deltaic depositional settings, reservoir quality sandstone units are often deposited in subsiding basins in conjunction with sea-level changes, allowing thick fluvial-deltaic sequences to accumulate and thicken over time (Scholle and Spearing, 1998). It is evident that large quantities of clay minerals in the Upper B Fourth Sand have increased the formation's irreducible water saturation, giving dramatically reduced resistivity values (10 - 15 OHMs) (Worthington, 2000 and Boyd et al., 1995). Lowresistivity sandstone reservoirs can produce water-free hydrocarbons; however water saturations found above fifty percent are usually not economic (Boyd et al., 1995).

A picket plot on the Upper B Fourth Sand interval (2041-2089 feet) indicates

fifty-percent water saturation and approximately fifty-percent hydrocarbon saturation (Figure 42). The presence of hydrocarbons and porosity is evident in the log via gas 


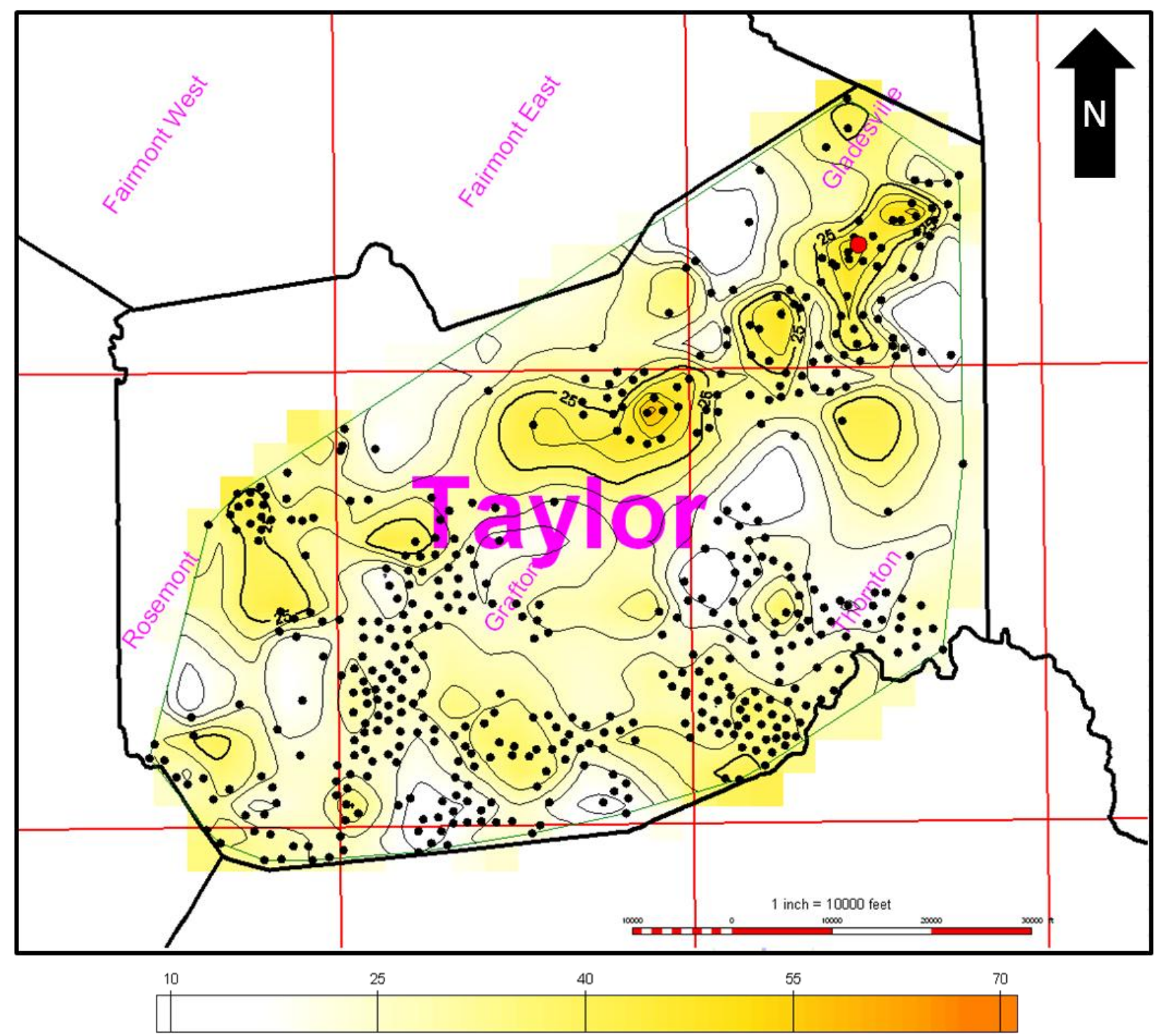

Map Legend

Well Location

Type Log-Core Plug

Figure 40. Upper B Fourth Net Sand Map with a gamma-ray cutoff of $90 \mathrm{API}$. Sand distribution is thick (average 17 feet) throughout the study area and prominent to the northwest. Contour interval $(\mathrm{Cl})$ is 5 feet $(1.5 \mathrm{~m})$. 


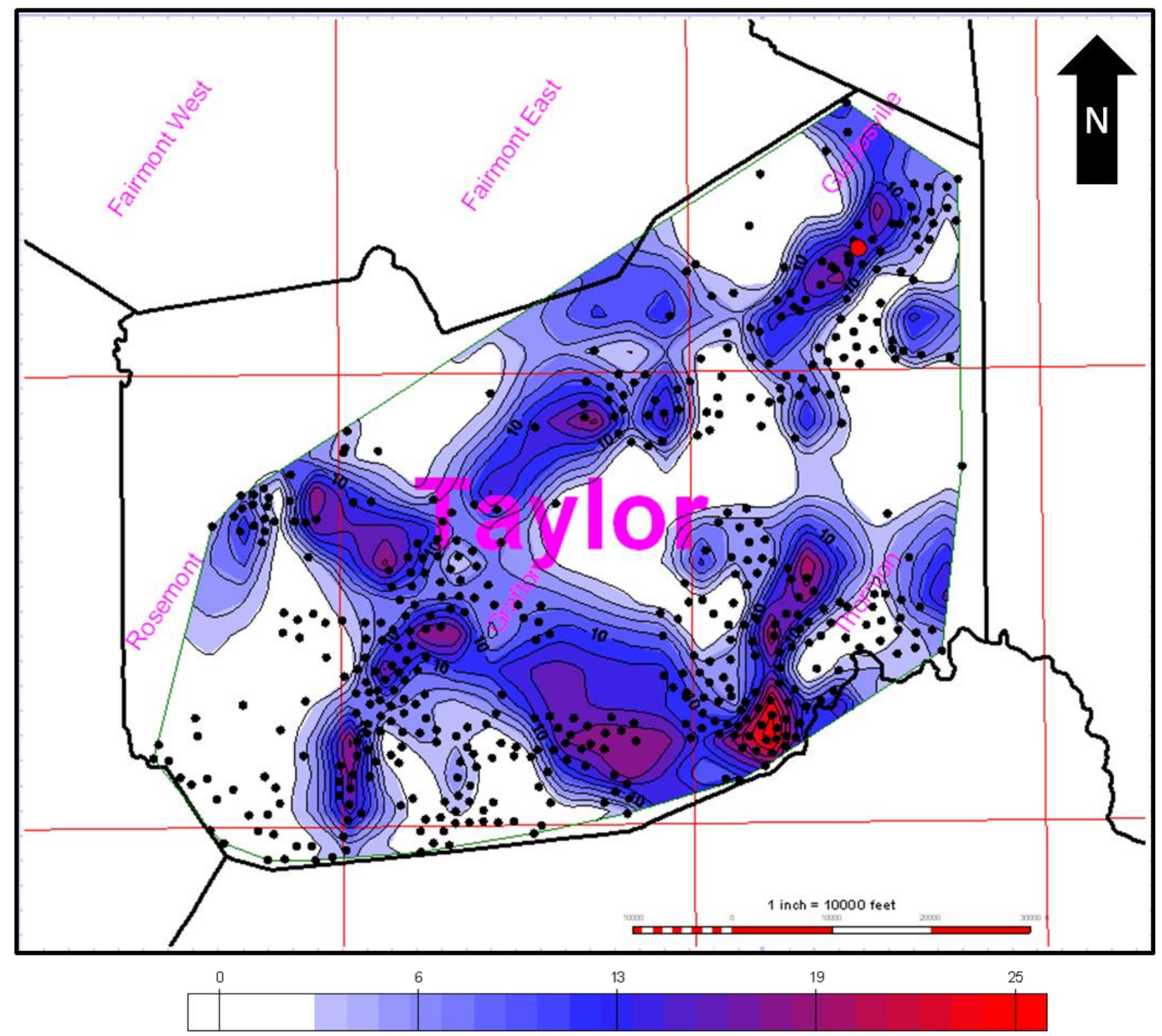

Map Legend

Well Location

Type Log-Core Plug

Figure 41. Upper B Fourth Degree of Cross-over Map with an average of 8 to 10 feet (2.5 to $3 \mathrm{~m})$. Contour interval $(\mathrm{Cl})$ is 2 feet $(0.6 \mathrm{~m})$ 


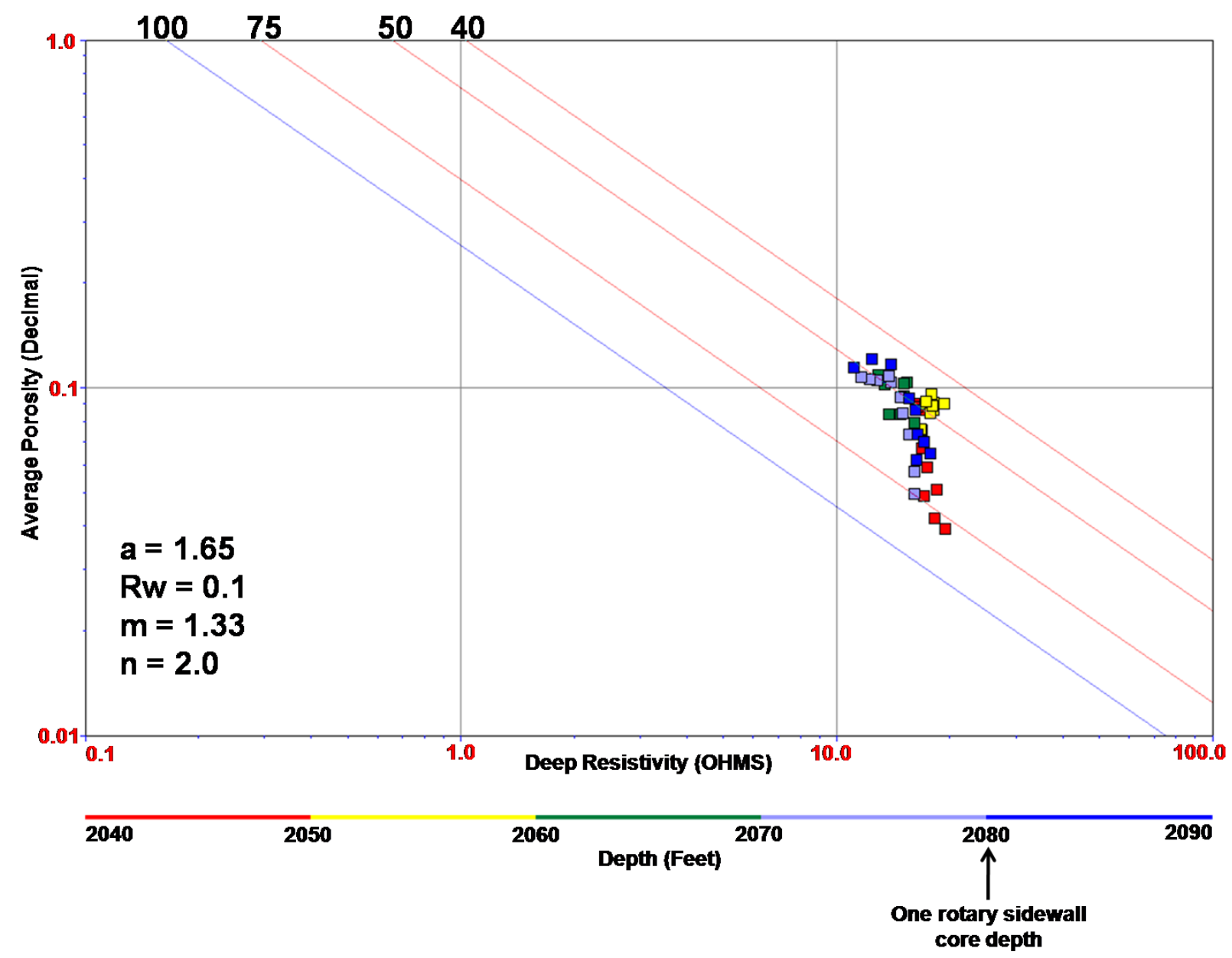

Figure 42. Pickett plot for Upper B Fourth Sand Type Log: Petroleum Development Corporation Williams-560, depth interval $2041-2089$ feet. The Upper B Fourth Sand is interpreted as hydrocarbon and water saturated. One rotary sidewall core is found at a depth of 2080 feet. 
effect, and density-neutron crossplot by way of data points located above the sandstone lithology line, and degree of cross-over map (Figures 16, 17, 31, and 41). The porosity observed in logs is confirmed by core data and observed in thin section. The Upper B Fourth Sand is found to be gas productive, but resistivity and log determined water saturation values are affected by clay bound water. In sandstone-shale hydrocarbonbearing zones, resistivity decreases over that of grains, and hydrocarbons due to the conducting nature of the bound water associated with the clay particles. Thus, shale can cause log resistivity to decrease in a pay zone.

The Upper B Fourth Sand production bubble map illustrates production trends

along the two interpreted fluvial-deltaic systems (Figure 43). Optimal hydrocarbon production is found toward the northeast corner of the study area, where sandstone is thick and porosity is high. Hydrocarbon production can relate to the degree of crossover and feet of net sand. Figure 44 indicates that the Upper B Fourth Sand is productive with at least 10 feet $(3 \mathrm{~m})$ of net sand and significant density-neutron crossover.

\section{Lower C Fourth Sand}

The argillaceous marine Lower C Fourth Sand net sand distribution is negligible with an average net sand thickness of 1 foot $(0.3 \mathrm{~m})$ occurs as scattered patches across the study area (Figure 45). The distribution of the Lower C Fourth Sand was confined to the north by extensive erosion of the Lower $C$ by the Upper B in the southern part of the study area. The sandbody has a low porosity with a limited to negible density-neutron cross-over in log view. Lithology crossplots indicate that the Lower C Fourth Sand consists of calcite (limestone), dolomite, and quartz minerals. 


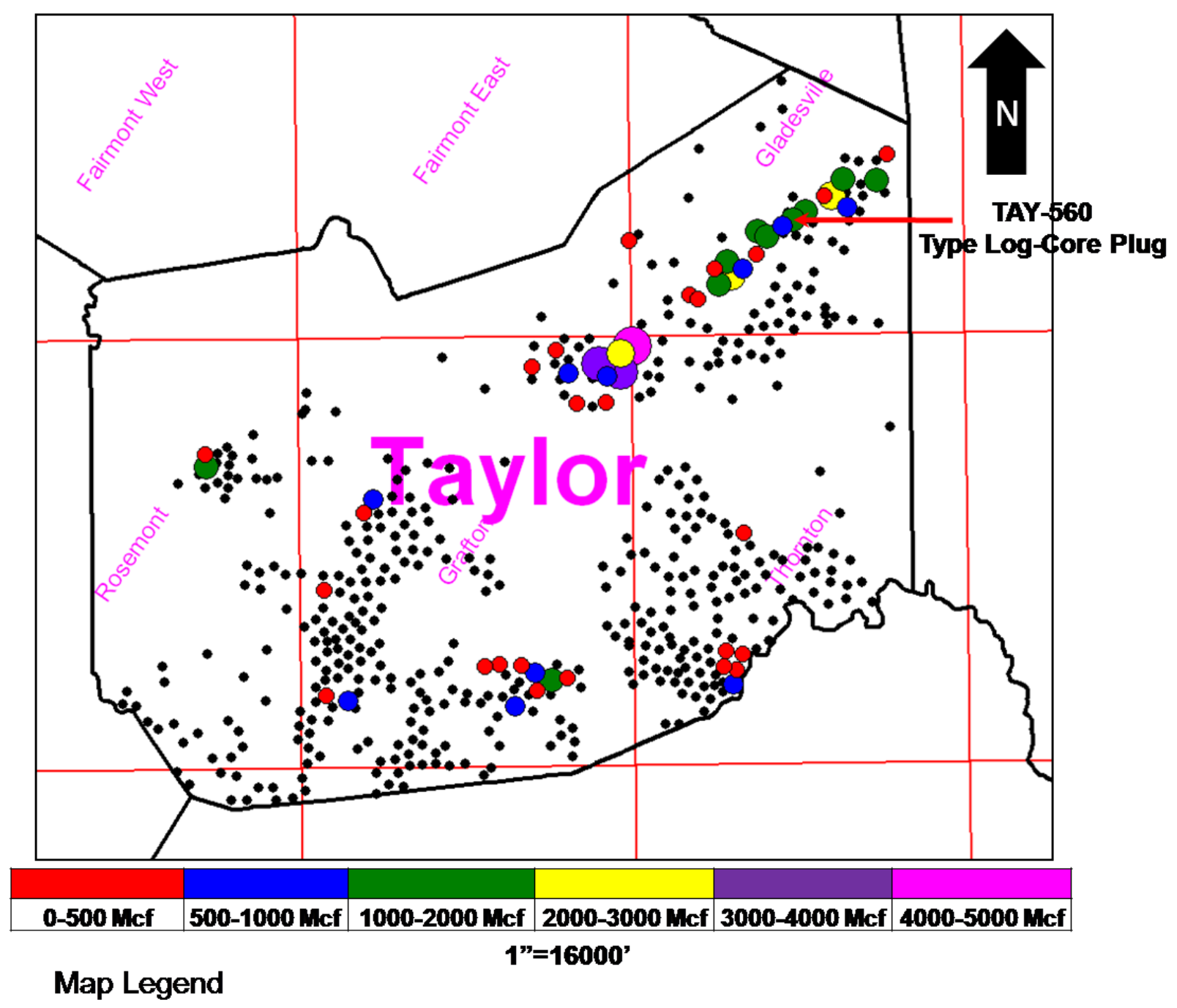

Well Location

Figure 43. Upper B Fourth Sand Production Bubble Map. Optimal hydrocarbon production is located in the northeast corner of the study area. 


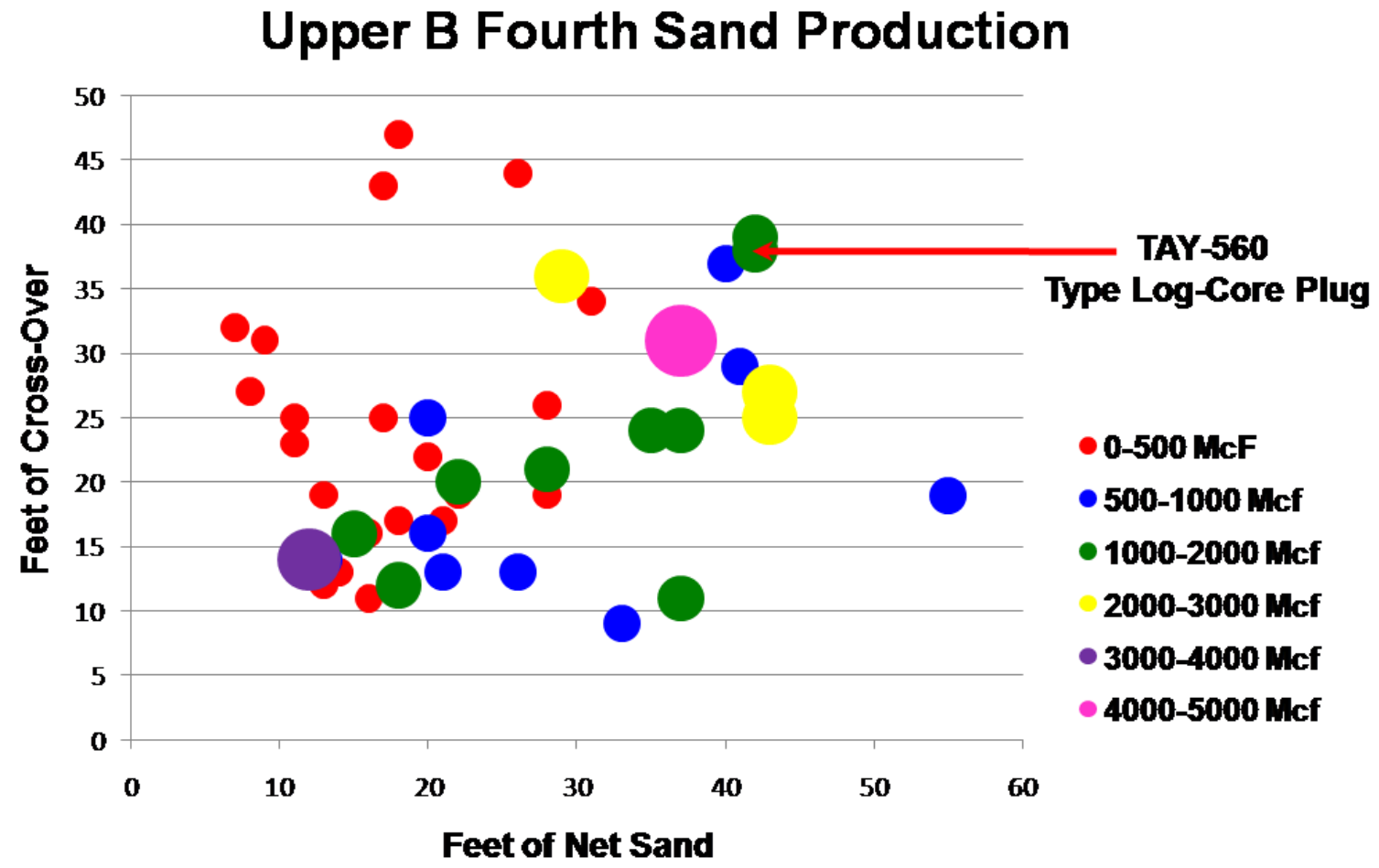

Figure 44. Upper B Fourth Sand Production Scatter Plot. The relationship between the degree of cross-over and feet of net sand indicates that the Upper B Fourth Sand can be found productive with 10 to 20 feet $(3$ to $6 \mathrm{~m}$ ) of net sand. There are no productive wells within less than 8 to 10 feet $(2$ to $3 \mathrm{~m})$ of density-neutron cross-over. 


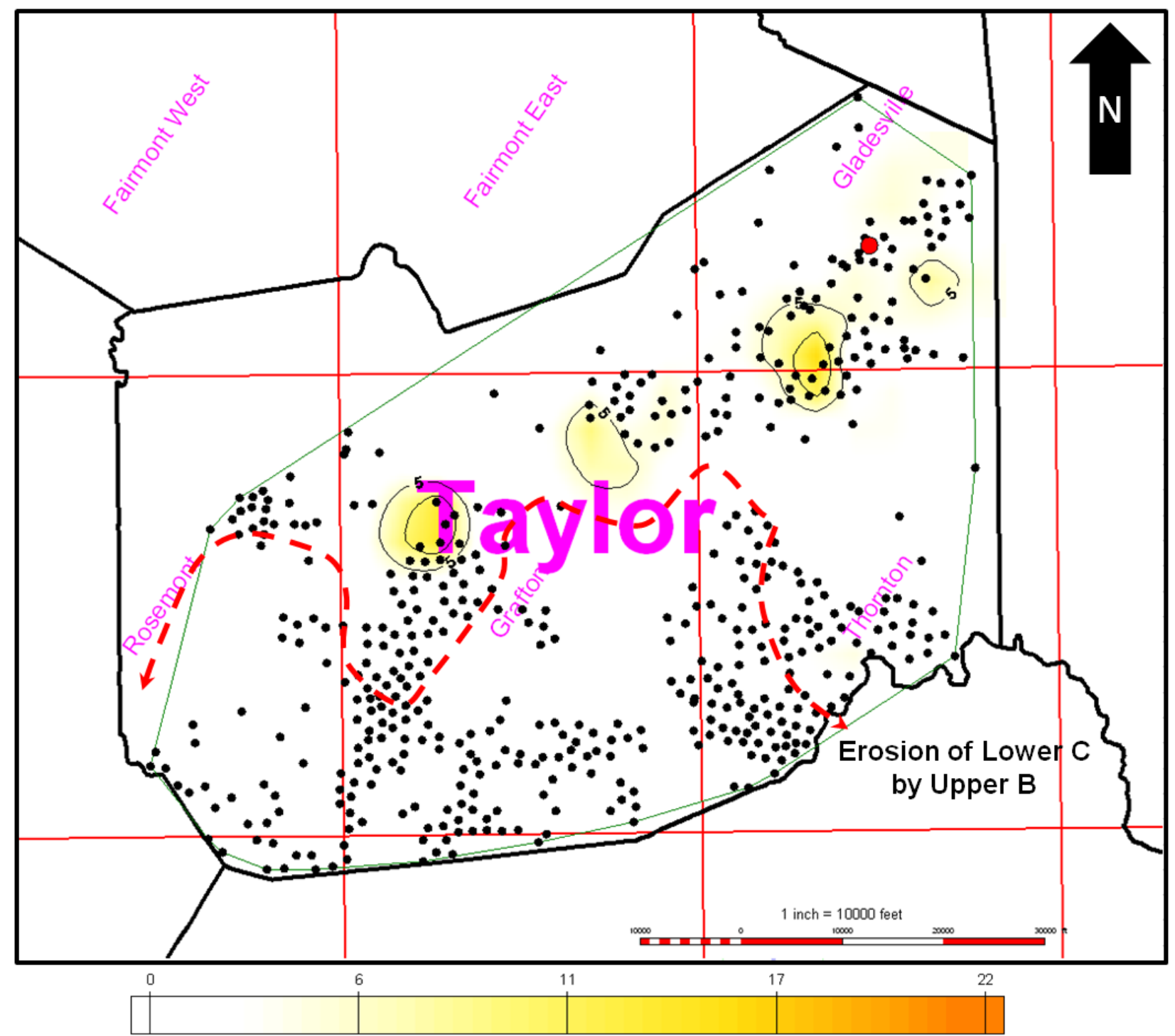

Map Legend

Well Location

Type Log-Core Plug

Figure 45. Lower C Fourth Net Sand Map with a gamma-ray cutoff of 90 API. Distribution is negligible with an average thickness of 1 foot $(0.3 \mathrm{~m})$. Contour interval $(\mathrm{Cl})$ is 5 feet $(1.5 \mathrm{~m})$. 
The Lower C Fourth Sand reduced porosity and hydrocarbons are attributed to unidentified clay minerals and calcite cement between intergranular sand grains. The degree of cross-over map was not constructed because cross-over between density porosity and neutron porosity curves were negligible. Production data was not found for the Lower C Fourth Sand unit; therefore, a production bubble map was not produced.

\section{Lower D Fourth Sand}

The fluvial-deltaic Lower D Fourth Sand net sand distribution is widespread and thin with an average of 7 feet $(2 \mathrm{~m})$ throughout the study area (Figure 46$)$. This sandbody has a relatively high degree of density-neutron cross-over with an average of 4 feet $(1 \mathrm{~m})$ (Figure 47). Lithology crossplots indicate that the Lower D Fourth Sand is dominated by quartz (sandstone), feldspar, and clay (illite). In comparison to the Upper B fluvial-deltaic sandstone sample data and thin section interpretations, the Lower D fluvial-deltaic Fourth Sand may also contain large quantities of clay minerals contributing to low-resistivity readings. In addition, the abundance of clay minerals could significantly decrease the reservoir quality of the Lower D Sand unit.

For the type log well, a Pickett plot on the Lower D Fourth Sand interval (21152142 feet) roughly illustrates a seventy-five-percent water saturation and twenty-fivepercent free hydrocarbons (Figure 48). The type log is not in an area of density-neutron cross-over and the Lower D Fourth Sand is interpreted as non-productive. The Lower D Fourth Sand is found gas productive, which is evident in another Lower D Pickett plot in the study area, as well as density-neutron crossplot and production bubble map (Figures 27, 49, and 50). 


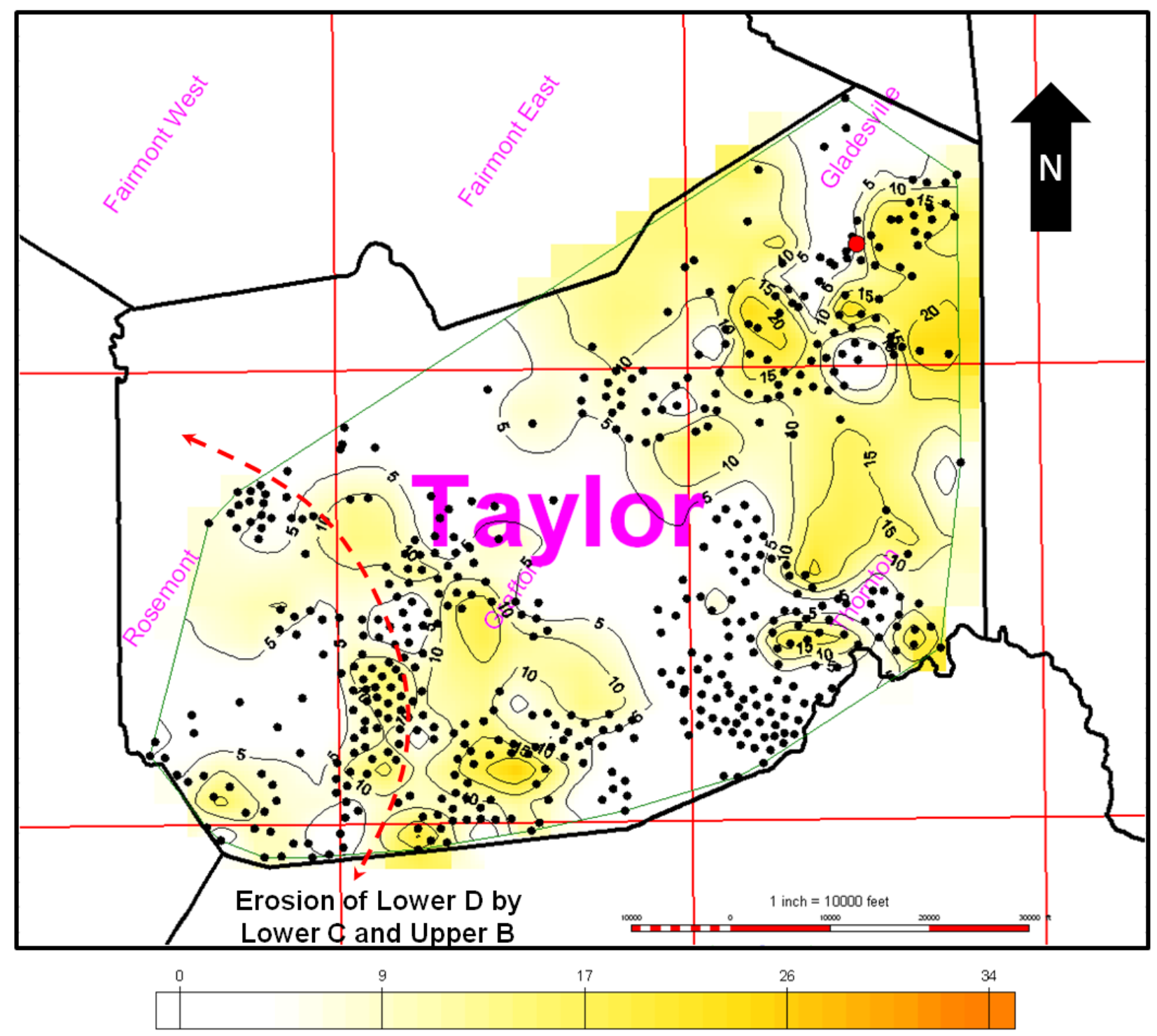

Map Legend

Well Location

Type Log-Core Plug

Figure 46. Lower D Fourth Net Sand Map with a gamma-ray cutoff of 90 API. Distribution is thin with an average of 7 feet $(2 \mathrm{~m})$ across the study area and thins to the southwest as a result of partial removal by erosional down cutting of the Upper B Fourth Sand. Contour interval $(\mathrm{Cl})$ is 5 feet $(1.5 \mathrm{~m})$. 

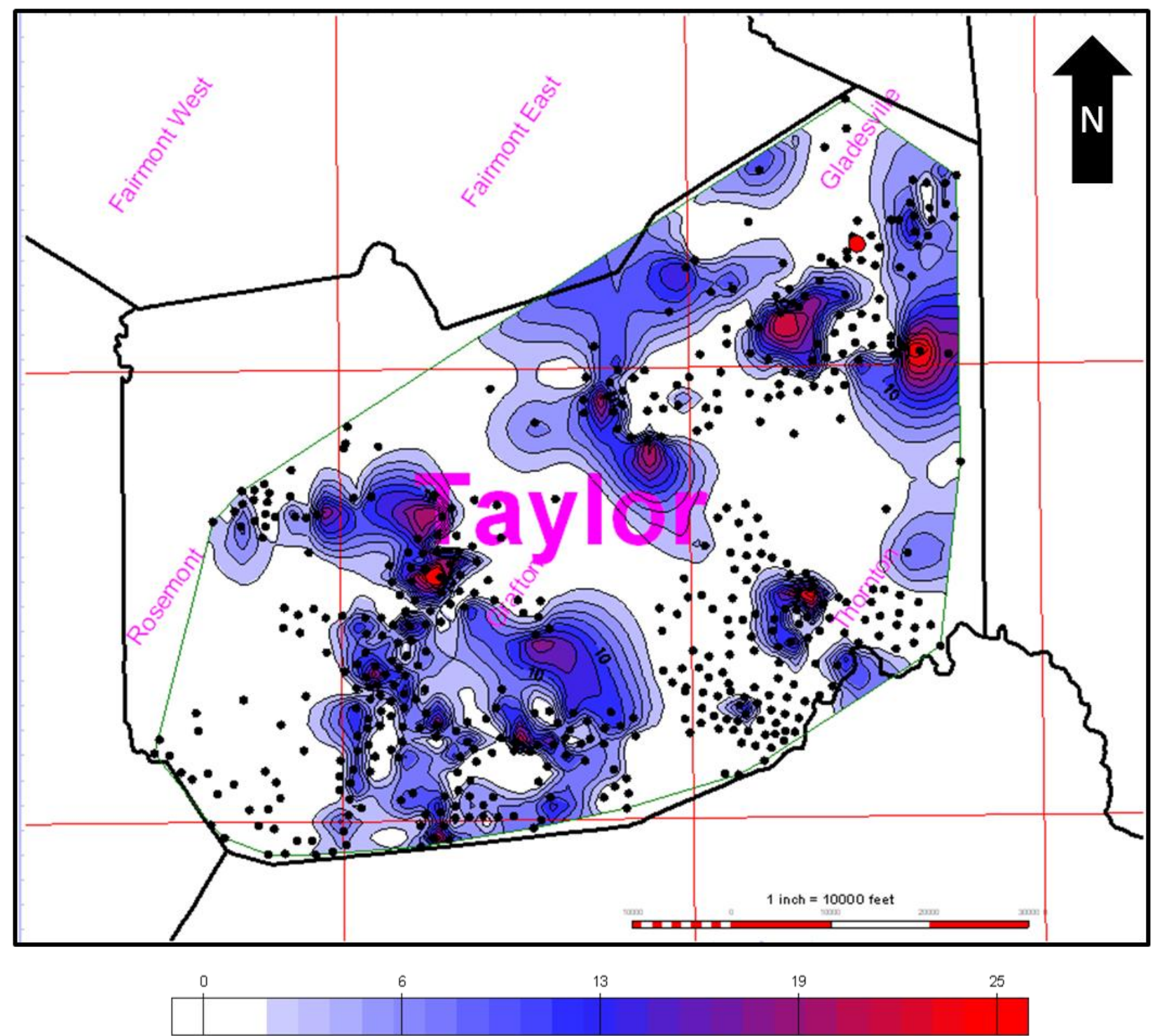

Map Legend

Well Location

Type Log-Core Plug

Figure 47. Lower D Fourth Sand Degree of Cross-over Map with an average of 6 to 8 feet ( 1 to $2.5 \mathrm{~m})$. Contour interval $(\mathrm{Cl})$ is 2 feet $(0.6 \mathrm{~m})$ 


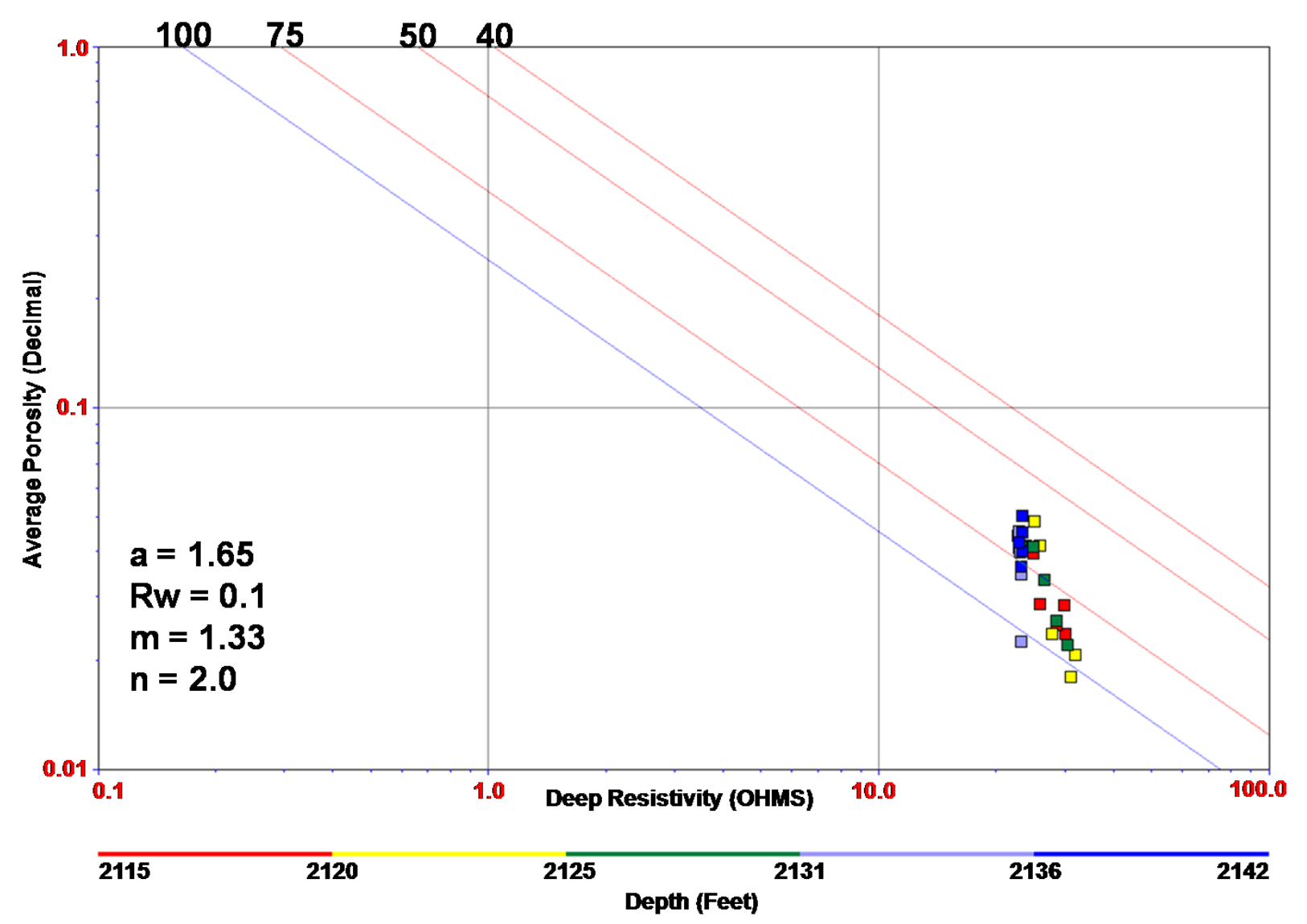

Figure 48. Pickett plot for Lower D Fourth Sand Type Log: Petroleum Development Corporation Williams-560, depth interval $2115-2142$ feet. For the type log, the Lower D Fourth Sand is interpreted as water saturated. 


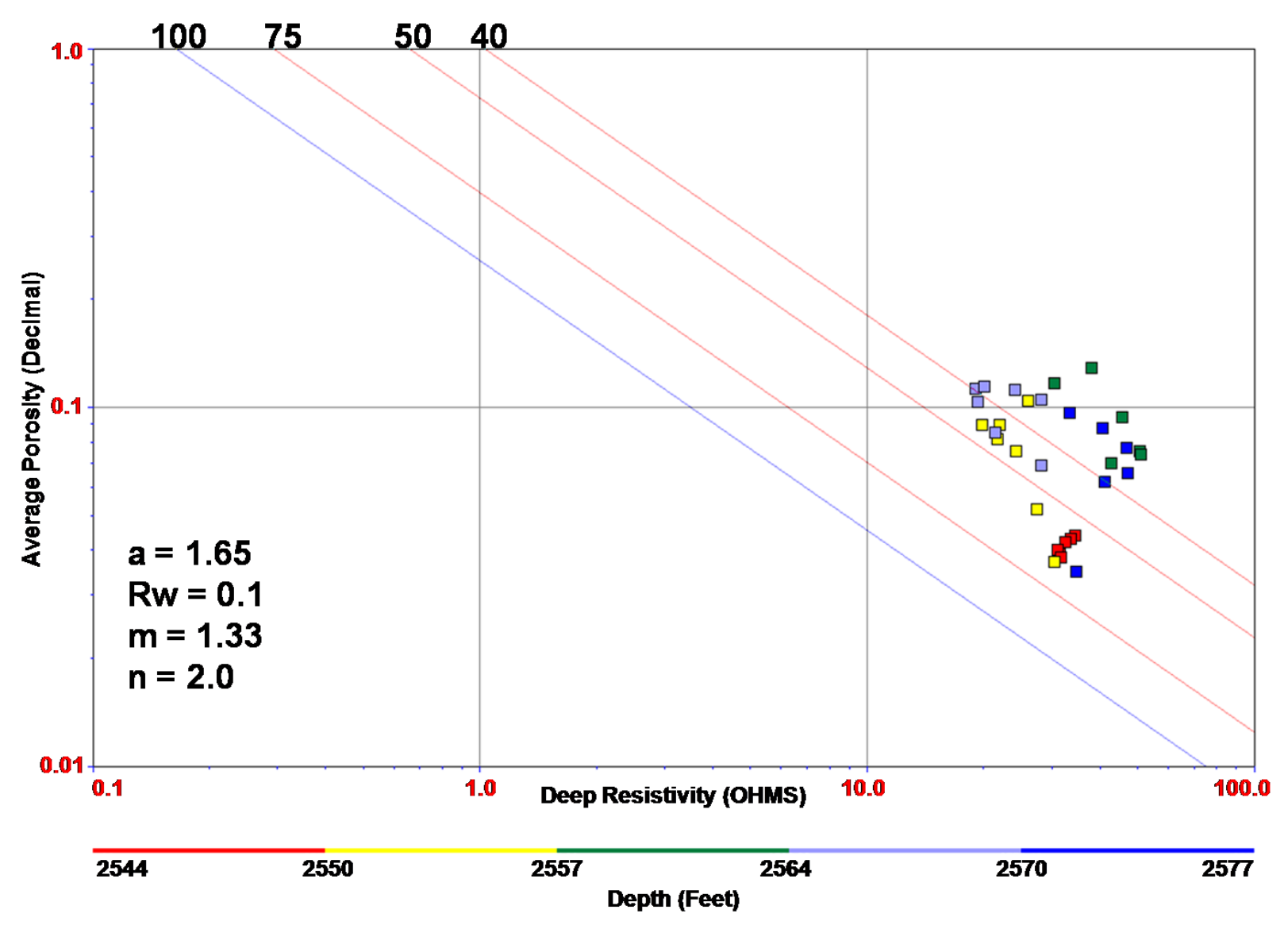

Figure 49. Pickett plot for Lower D Fourth Sand: Petroleum Development Corporation Frey-808, depth interval $2544-2577$ feet. The Lower D Fourth Sand is interpreted as hydrocarbon saturated. 


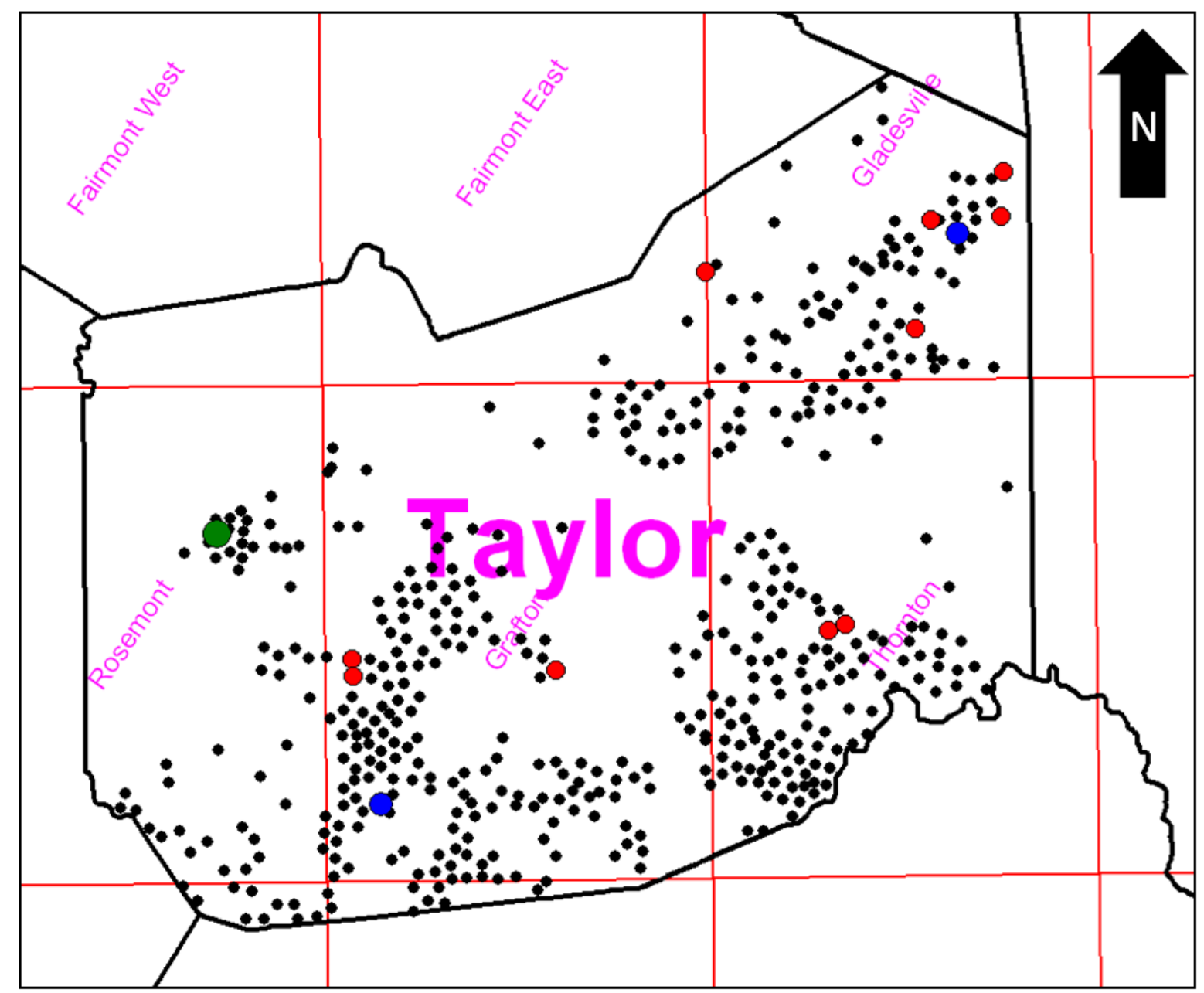

\begin{tabular}{l|l|l|l|l|l|}
$0-500 \mathrm{Mcf}$ & $500-1000 \mathrm{Mcf}$ & $1000-2000 \mathrm{Mcf}$ & $2000-3000 \mathrm{Mcf}$ & $3000-4000 \mathrm{Mcf}$ & $4000-5000 \mathrm{Mcf}$ \\
\hline
\end{tabular} Map Legend $1 "=16000^{\prime}$

Well Location

Figure 50. Lower D Fourth Sand Production Bubble Map. Hydrocarbon production is limited across the study area. 
The Lower $\mathrm{D}$ bubble map indicates that production is limited and scattered across the two interpreted fluvial-deltaic systems. Hydrocarbon production can relate to the degree of cross-over and feet of net sand. Figure 51 indicates that the Lower D Fourth Sand can be found productive with an approximately 10 feet of cross-over with at least 8 feet of net sand. The Lower D Fourth Sand is over most of the study area unproductive and low-resistivity reservoirs with water saturations above fifty-percent are uneconomic; though there may be other areas that the Lower $D$ could be productive (Boyd et al., 1995). 


\section{Lower D Fourth Sand Production}

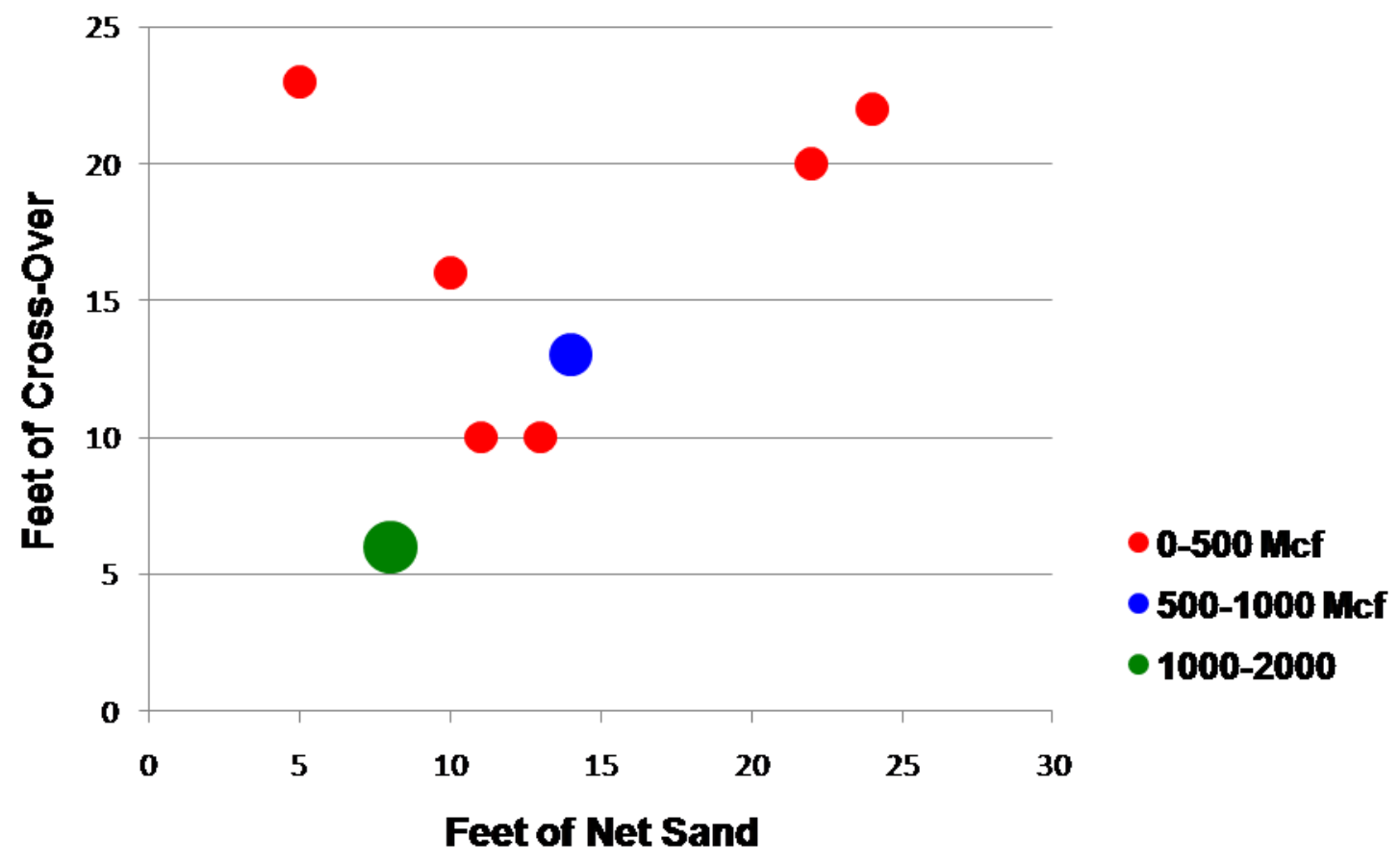

Figure 51. Lower D Fourth Sand Production Scatter Plot. The relationship between the degree of cross-over and feet of net sand indicates that the Lower D Fourth Sand can be found productive with approximately 10 feet $(3 \mathrm{~m})$ of cross-over and at least 8 feet $(2$ $\mathrm{m})$ of net sand. 


\section{CONCLUSIONS}

Based primarily on log response, the Upper Devonian Fourth Sand can be subdivided, correlated, and mapped into four different sandstone units: Upper A Fourth Sand, Upper B Fourth Sand, Lower C Fourth Sand, and Lower D Fourth Sand. Two dominant depositional environments were described and identified as deposited along a muddy shoreline in a shallow foreland-ramp basin; strike-trending marine sandstone and dip-trending fluvial-deltaic systems. The Upper A and Lower C Fourth Sand units were described and interpreted as marine argillaceous sandstone, and Upper B and Lower D Fourth Sand units were inferred as fluvial-deltaic argillaceous sandstone.

Density-neutron lithology crossplots and RHOmaa-Umaa mineral identification crossplots were used to describe the composition of each Fourth sandstone unit. Upper A and Lower C Fourth sandbodies consist of calcite (limestone), clay (illite), and quartz minerals, which are interpreted as shallow marine, calcite-cemented sandstone units. The Upper A and Lower C Fourth Sand units also have a low porosity, which is apparent in the type log and negligible density-neutron degree of cross-over data. In addition, production was not reported from the Upper A and Lower C Fourth Sand units. The marine Upper A and Lower C Fourth Sand units are interpreted as non-productive because porosity has been significantly reduced by calcite-cemented sand grains.

The Upper B and Lower D Fourth Sand composition consists of quartz, feldspar, and abundant clay (illite) minerals. These Fourth Sand fluvial-deltaic argillaceous sandstone units commonly display low-resistivity values, due to the large quantities of clay minerals filling pore spaces and coating intergranular sand grains. The Upper B Fourth Sand thin section shows large quantities of unidentified reddish-brown clay 
material, elongate muscovite grains filling pore spaces and squeezed between sand grains, and minor amounts of chlorite grains. Large quantities of clay minerals increase bound water saturation and decrease a formation's porosity; however, the Upper B and Lower D Fourth Sand units are gas productive with negligible water production. The high water saturation is attributable to irreducible water bound to clay particles.

Available production data indicate that the Upper B Fourth Sand is the most favorable reservoir of interest and contains optimal hydrocarbon production throughout the study area. The Lower D Fourth Sand is gas productive, though is more restricted in its areal distribution. Low-resistivity pay sands can be quite prolific produces and to overcome the argillaceous composition and restricted porosity of these reservoir units, hydraulic fracturing and acidization completion methods may be required to optimize recovery and enhance production. 


\section{REFERENCES}

Asquith, G., and D. Krygowski, 2004, Basic well log analysis: Tulsa, OK, AAPG, 240 p.

Boswell, R. M., 1985, Stratigraphy and sedimentation of the Acadian clastic wedge in northern West Virginia, Master's thesis, West Virginia University, Morgantown, West Virginia, $179 \mathrm{p}$.

Boswell, R. M., and A. C. Donaldson, 1988, Depositional architecture of the Upper Devonian Catskill delta complex: central Appalachian basin, U.S.A.: Canadian Society of Petroleum Geologists, v. 14, p. 65-84.

Boswell, R. M., and G. A. Jewell, 1988, Atlas of Upper Devonian/Lower Mississippian sandstones in the subsurface of West Virginia: West Virginia Geological and Economic Survey, $144 \mathrm{p}$.

Boyd, A., Darling, H., Tabanou, J., Davis, B., Lyon, B., Flaum, C., Klein, J., Sneider, R. M., Sibbit, A., and J. Singer, 1995, The lowdown on low-resistivity pay: Oilfield Review, p. 4-18.

Castle, J. W., 2000, Recognition of facies, bounding surfaces, and stratigraphic patterns in foreland ramp successions: an example from the Upper Devonian, Appalachian basin, U.S.A.: Journal of Sedimentary Research, v. 70, no. 4, p. 896-912.

Castle, J. W., 2001, Appalachian basin stratigraphic response to convergent-margin structural evolution: Basin Research, v. 13, p. 397-418.

Castle, J. W., 2001, Foreland-basin sequence response to collisional tectonism: GSA Bulletin, v. 113, no. 7, p. 801-812.

Ettensohn, F.R., 1985a, The Catskill delta complex and the Acadian orogeny, in Woodrow, D.L. and Sevon, W.D., eds., The Catskill delta: Geological Society of America Special Paper 201, p. 39-49.

Ettensohn, F.R., 1985b, Controls on development of Catskill delta complex basin-facies, in Woodrow, D.L. and Sevon, W.D., eds., The Catskill delta: Geological Society of America Special Paper 201, p. 65-77.

Jewell, G. A., 1988, Stratigraphy and depositional environments of Upper Devonian and Lower Mississippian sandstones of southeastern West Virginia, Master's thesis, West Virginia University, Morgantown, West Virginia, $133 \mathrm{p}$.

Lessing, P., 1996, West Virginia geology physiographic provinces: West Virginia Geological and Economic Survey, http://www.wvgs.wvnet.edu. 
Lewis, J. S., 1983, Reservoir rocks of the Catskill delta in northern West Virginia: stratigraphic basin analysis emphasizing deposystems, Master's thesis, West Virginia University, Morgantown, West Virginia, $148 \mathrm{p}$.

Milici R. C., and C. S. Swezey, 2006, Assessment of Appalachian basin oil and gas resources: Devonian shale - Middle and Upper Paleozoic total petroleum system: U. S. Geological Survey Open-File Report 2006-1237, p. 9-54.

Mumcuoglu, C. H., 1984, Detailed deposystem analysis of reservoir sandstones of Catskill delta, north-central West Virginia, Master's thesis, West Virginia University, Morgantown, West Virginia, $129 \mathrm{p}$.

Peace, K. K., 1985, Detailed deposystem analysis of the sandstones in the Upper Devonian - Lower Mississippian Acadian clastic wedge, northern West Virginia, Master's thesis, West Virginia University, Morgantown, West Virginia, 275 p.

Roen, J. B, and B. J. Walker, 1996, Play DVS: Upper Devonian Venango sandstones and siltstones, in R. M. Boswell, L. R. Heim, G. R. Wrightstone, and A. Donaldson, The Atlas of major Appalachian gas plays, West Virginia Geological and Economic Survey, p. $63-69$.

Rowan, E.L., 2006, Burial and thermal history of the central Appalachian basin, based on 3 2-D models of Ohio, Pennsylvania, and West Virginia; U.S. Geological Survey Open-File Report 2006-1019, 35 p.

Rowan, E.L., Ryder, R.T., Repetski, J.E., Trippi, M.H., and Ruppert, L.F., 2004, Initial results of a 2D burial/thermal history model, central Appalachian basin, Ohio and West Virginia: U.S. Geological Survey Open-File Report 2004-1445, 38 p.

Ryder, R. T., 1995, Appalachian basin province (067), in Gautier, D. L., Dolton, G. L., Schlumberger, 2009, Log interpretation charts, 278 p.

Scholle, P. A., and D. Spearing, 1998, Sandstone depositional environments: Tulsa, OK, AAPG, $405 \mathrm{p}$.

Wilson, B. W., and R. H. Nanz, 1959, Sand conditions as indicated by the self-potential log: EPR Memorandum Report 51, $17 \mathrm{p}$.

Worthington, P. F., 2000, Recognition and evaluation of low-resistivity pay: Petroleum Geoscience, v. 6, p. 77-92. 